DOE/BP/ $35397--1$

DE9 1006263

\title{
Biomass Estimates for Five Western States
}

Submitted by: Jarnes 0 . Howard

Research Forester

USDA, Forest Service

Pacific Northwest Research Station

Submitted to: Pacific Northwest and Alaska

Regional Bioenergy Program

Principal Funding: U.S. Department of Energy

Program Management: Bonneville Power Administration Interagency Agreement DE-AI79-87BP35397

October 1990
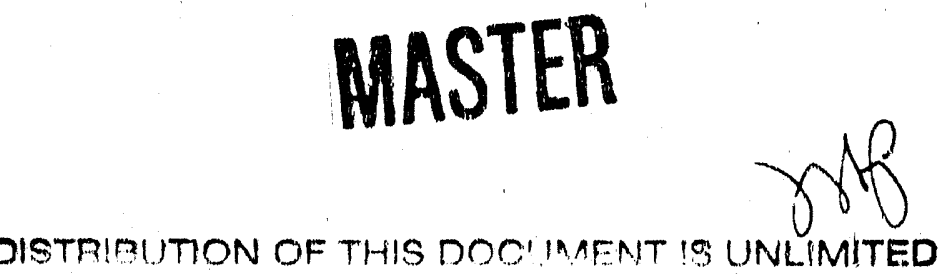
List of Tables

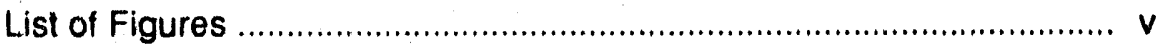

Table of Contents

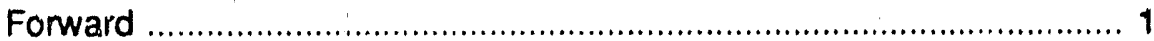

Introduction .................................................................................... 3

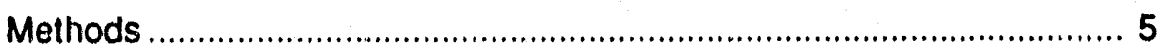

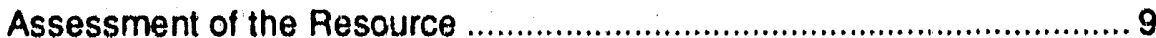

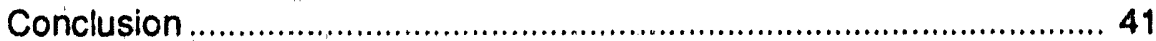

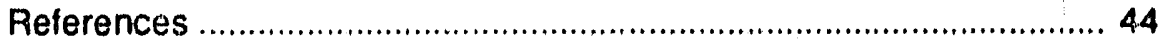

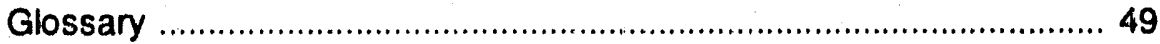

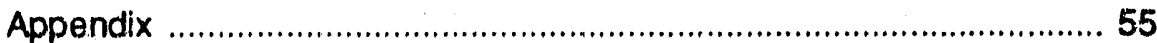

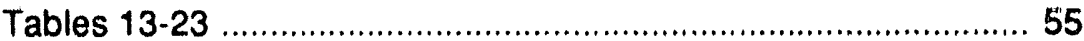

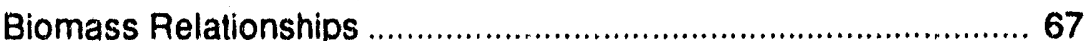

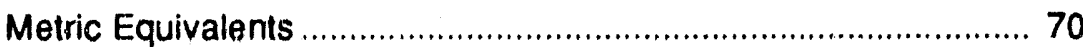

\section{DISCLAIMER}

This report was prepared as an account of work sponsored by an agency of the United States Governme nt. Neither the United States Government nor any agency thereof, nor any of their employees, makes any warranty, express or implied, or assumes any legal liability or responsibility for the accuracy, completeness, or usefulness of any information, apparatus, product, or process disclosed, or represents that its use would not infringe privately owned rights. Refer. ence herein to any specific commercial product, process, or service by trade name, trademark, manufacturer, or otherwise does not necessarily constitute or imply its endorsement, recom. mendation, or favoring by the United States Government or any agency thereof. The views and opinions of authors expressed herein do not necessarily state or reflect those of the United States Government or any agency thereof.

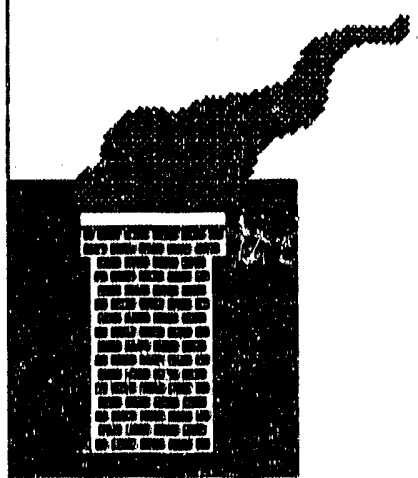




\section{Acknowledgments}

Biomass information presented in this report is based on inventory data made available by the U.S. Department of Agriculture, Forest Service. Inventory statistics were derived from published and unpublished reports from the following offices:

- Pacific Northwest Research Station

Forest Inventory and Analysis Research Units Anchorage, Alaska and Portland, Oregon

- Intermountain Research Station

Forest Inventory and Analysis Research Unit Ogden, Utah

Special acknowledgment is given to the personnel from these Forest Service Research Units for providing critical review of methods used to develop biomass tables displayed in this report.

The author and Forest Service wish to thank the U.S. Department of Energy, (Bonneville Power Administration), through the Pacific Northwest and Alaska Regional Bioenergy Program, for their support of this undertaking. Their recognition of the need for a comprehensive biomass data base for this region has resulted in an important baseline for further development of the role of our forests in meeting future energy needs. 
Table 1. Total land area by State, resource area, and land class.

Table 2. Area of limberland by State, resource area, and ownership.

Table 3. Area of timberland by State, resource area, and stand-size class.

Table 4. Total dry weight of above ground biomass on timberland by State, resource area, and class of timber.

Table 5. Total green weight of above ground biomass on timberland by State, resource area, and class of timber.

Table 6. Dry weight per acre of above ground biomass of growing stock trees on timberland by State, rosource area, arid ownership.

Table 7. Total dry weight of above ground biomass of growing stock irees on timberland by State, resource area, softwoods and hardwoods, and by bole and crown.

Table 8. Dry weight per acre of above ground biomass of growing stock trees on timberland by State, resource area, softwoods and hardwoods, and by bole and crown.

Table 9. Total dry weight of above ground biomass of live trees on timberland by State, resource area, and diameter class.

Table 10. Total dry weight of net annual growth of growing stock trees on timberland by State, resource area, and ownership.

Table 11. Total gross and net weight (wood and bark) of logging residue by area, ownership, and harvest method.

Table 12. Energy values of potentially available woodly biomass by State, resource area, and source.

Table 13. Area of timberland by State, resource area, and forest type.

Table 14. Area of timberland by State, resource area, and cubic-toot site class.

Table 15. Total dry weight of above ground biomass of growing stock trees on timberland by State, resource area, and ownership. 
Table 16. Total dry weight of above ground biomass of growing stock

trees on timberland by State, resource area, and species.

Table 17. Dry weight per acre of net annual growth of growing stock trees on timberland by State, resource area, and ownership.

Table 18. Average gross volume (wood and bark) of logging residue by area, ownership, and harvest method.

Table 19. Average net volume (wood and bark) of logging residue by area, ownership, and harvest method.

Table 20. Average net dry weight of logging residue by area, ownership, and harvest method.

Table 21. Average gross volume (wood only) of logging residue by area, ownership, harvest method and live or dead/cull material.

Table 22. Average gross volume (wood only) of logging residue per acre by area, ownership, harvest method, and small-end diameter and length classes.

Table 23. Average number of pieces of logging residue per acre by area, ownership, harvest method, and small-end diameter and length classes. 
Figure 1. Map of study area showing resource areas

Figure 2. Generalized forest zones within 5-State area

Figure 3. Total land area by classification by resource area

Figure 4. Percent of timberland by ownership ciass by resource area

Figure 5. Percent of timberland by stand-size class by resource area

Figure 6. Percent of timberland by forest type by resource area

Figure 7. Proportion of total timberland compared to proportion of total biomass by area

Figure 8. Percent of total biomass by stand-size class by resource area

Figure 9 . Biomass distribution (percent) by diameter class by resource area

Figure 10. Gross and net weight of logging residue by area

Figure 11. Proportion of total energy potential for each source

Figure 12. Distribution of total biomass inventory by source by resource area

Figure 13. Small size residue (less than 3.0 inches) such as this may be available for energy

Figure 14. Cull trees, which contain logs like this, and dead trees are a significant but widely scattered resource

Figure 15. Recovery of biomass from thinning small trees may be an important source of wood for energy in the future 

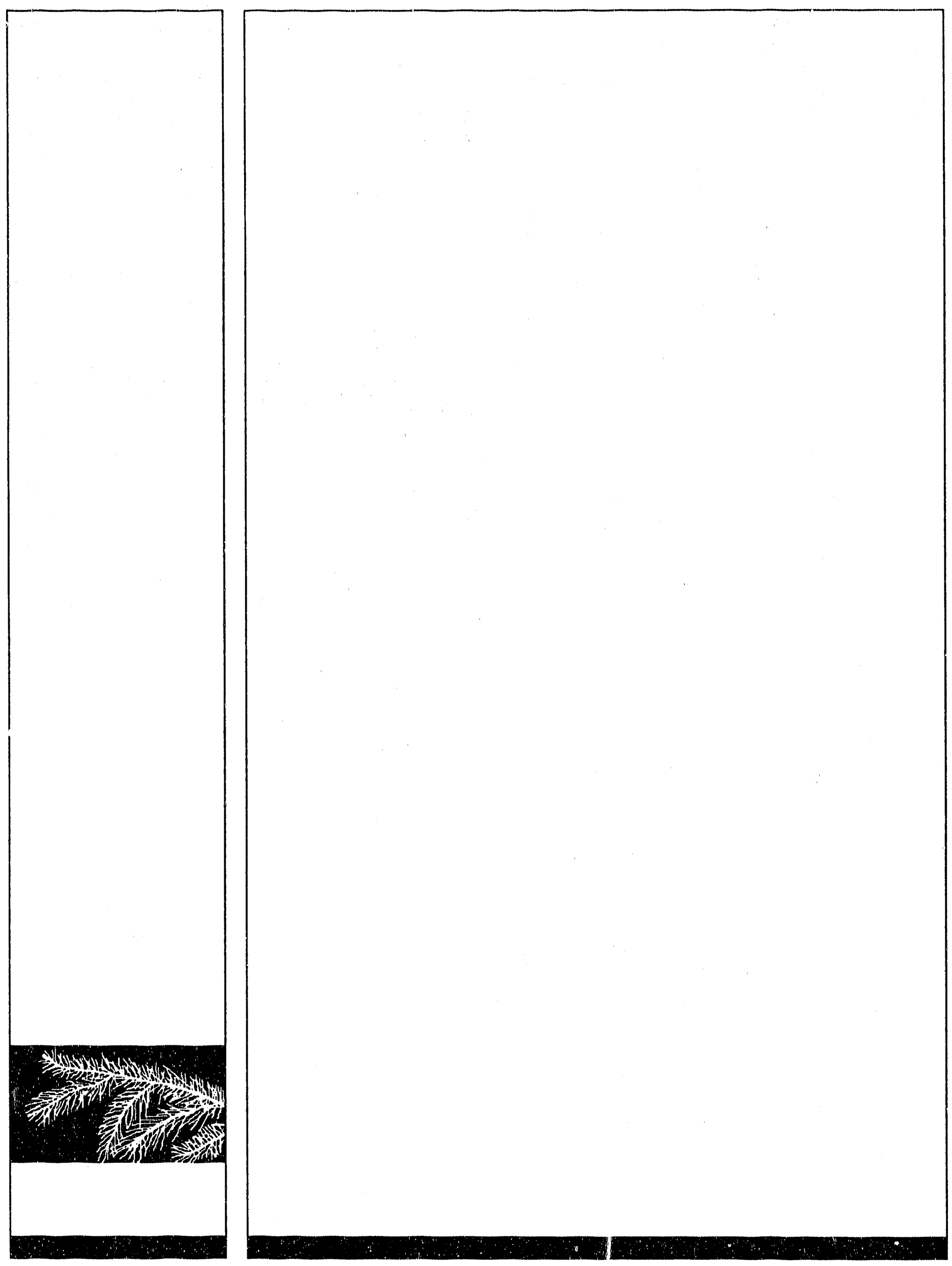
The purpose of this report is to describe the woody biomass resource within U.S.

Department of Energy's Pacific Northwest and Alaska Regional Biomass Program, comprised of southeast Alaska, Idaho, Montana, Oregon, and Washington. In addition to the regional forest biomass assessment, information will be presented for logging residue, which represents current energy conversion opportunities.

The information presented in the report is based on data and relationships already published. Regionally applicable biomass equations are generally not available for species occurving in the west. Because of this, a number of assumptions were made to develop whole-tree biomass tables. These assumptions are required to link algorithms from biomass studies to regional timber inventory data published by the Forest Inventory and Analysis Research Units (FIA), of the Pacific Northwest and Intermountain Research Stations, U.S. Forest Service. These sources and assumptions will be identified later in this report. Tabular biomass data will be presented for 11 resource areas, identified in the FS inventory publications. These areas are shown below:

\begin{tabular}{llcc} 
State & Resource Areas & $\begin{array}{c}\text { Inventory } \\
\text { Date }\end{array}$ & References \\
\hline SE Alaska & Entire are & $1970-1976$ & (23), (24), (33-37) \\
Idaho & Entire State & 1981 & $(6)$ \\
Montana & Entire State & 1980 & $(15)$ \\
Oregon & Northwest & 1977 & $(13)$ \\
& West Contral & 1975 & $(13)$ \\
& Southwest & 1975 & $(13)$ \\
& Eastern & 1977 & $(11)$ \\
Washington & Olymple Peninsula & 1980 & $(3)$ \\
& Puget Sound & 1979 & $(1)$ \\
& Southwest & 1978 & $(2)$ \\
& Eastern & 1981 & $(5)$
\end{tabular}




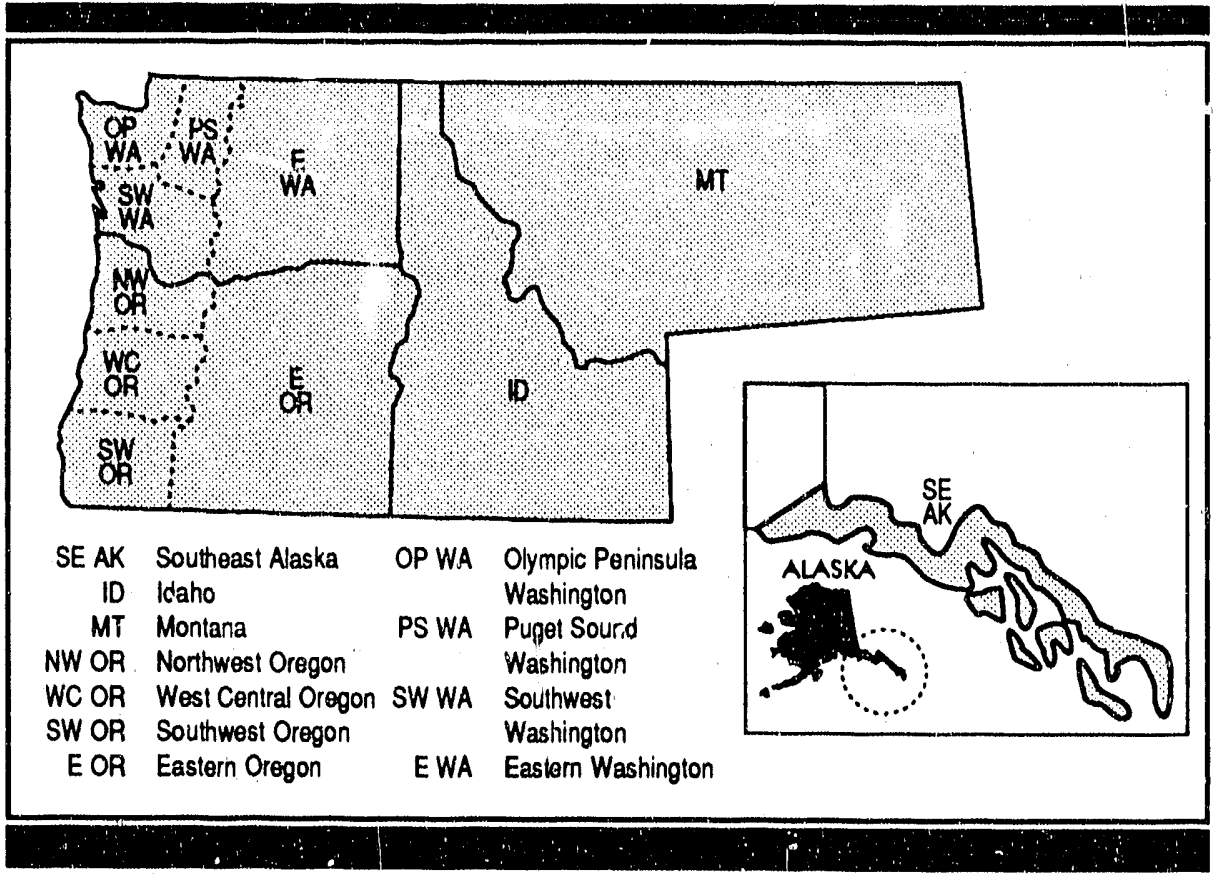

Figure 1: Map of study area showing resource areas

This report does not include information for the vast area encompassing interior Alaska. Comparable inventory data are not available for this area thus biomass tables could not be developed. In addition, much of the interior area is inaccessible to conventional harvesting operations or is in areas considered to be sensitive to these operations. Thus it is doubtful if the biomas ; resource of this area could generate significant outputs urider these circumstances.

Total tree biomass as defined in the report refers to the above ground weight of a tree above a 1.0 foot stump, and exclusive of foliage. A glossary is included that defines specific terms as used in the report. Inventory terminology is derived from forest inventory reports from Forest Inventory and Analysis units at the Intermountain and Pacific Northwest Research Stations.

Significant highlights and relationships of the regional resource will be shown in a series of graphs and charts. 
The five western States representing the Pacific Northwest and Alaska Regional Biomass Program of the U.S. Department of Energy, cover about 256 million acres of land and contain approximately one-third of the Nation's timber resource (U.S. Department of Agriculture 1981b). This vast resource is concentrated on approximately 30 percent of the total area, referred to as timberland; land supporting timber that is generally considered to be available for continuing production of woody fiber (see figure 2 for general forest zones). This resource supports a large forest products industry, accounting for a significant share of the wood products consumed ir United States. This resource also represents a source of supply for a potentially significant wood using industry-energy. Energy production based on woody biomass ${ }^{1}$ grew considerably following the fuel shortages of the mid-seventies. This growth occurred primarily within the forest products industry and residential sectors of the economy. New legislation, advancing technology, and the renewable nature of wood provide the basis for greater reliance on biomass as a contributor to the region's energy needs in the future.

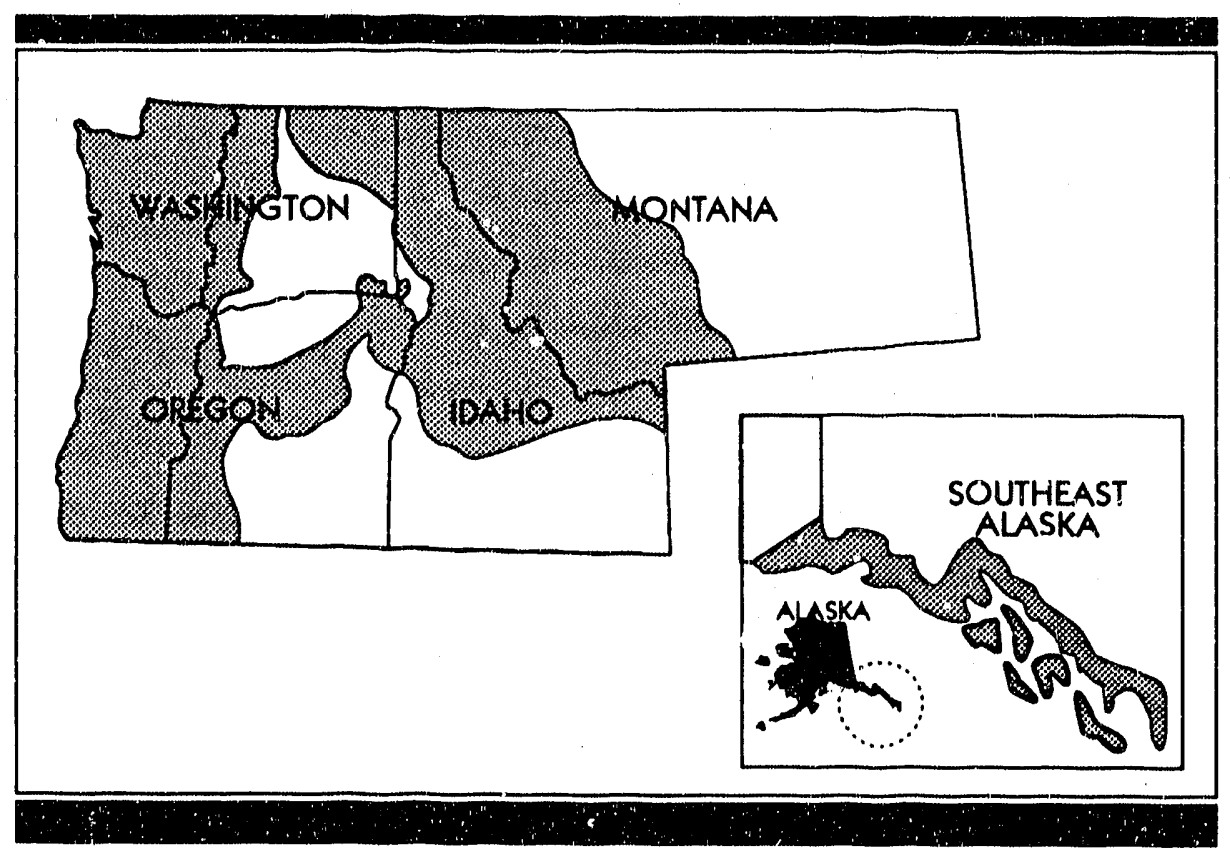

Figure 2: Generalized forest zones within 5-State area

' See Glossary for terms used in this report. 
The current surplus of energy in the region, while dwindling, has temporarily slowed the rate of growth of consumption of wood for energy. An examination of the wood energy situation in California, however, gives a good indication of changes that mighi be expected in the near future in this five-State region.

Based on different economic and energy supply and demand relationships, the use of woody biomass for energy in California has expanded rapidly in the last five years. Information from energy producers in that State indicate that total demand for wood by all existing and planned facilities equals alrnost 10 million tons annually. This expansion has resulted in some energy producers looking to other areas for potential sources of wood supply. Where and how this growth in the use of wood for energy will occur is an important question. A better understanding of the region's vast timber resource is a prerequisite for addressing this question. Adequate information exists to evaluate the suppiy needed by conventional wood product industries. What is needed, however, is more information on the entire woody biomass resource. This report brings together the best data available on the woody biomass resource of the 5-State area, as input to energy and other wood products industries and decisionmakers considering the above question. This report does not add to the depth and precision of biomass data, a major issue faced by all woody biomass users and managers in the West. This need must be met before the region's biomass resource can be effectively managed.

The primary purpose of this report is to identify significant sources of woody biomass that may have potential for supplying current or future energy conversion facilities. No attempt is made to define amounts that might be available to a specific location. This is a large task, needing information on a complex set of criteria that affect the nhysical and economic feasibility of using woody biomass for energy. Because of this complexity, and additional consiraints related to forest management objectives, estimates of the total amount of biomass that might be available on an annual basis were not made. An exception to this are the logging residue data, which are based on annual harvest levels. 
Area figures were iaken directly from the FIA inventory reports noted above. Total land area represents all land within the State boundaries, except bodies of water so designated by the Bureau of Census. Timbertand is that area considered to be suitable for producing continuing crops of trees, and not withdrawn from timber production for various reasons. Trees do occur on other lands, but are not considered for future tirnber production because of statute, low productivity, or other special use designations.

Inventory volumes (cubic feet) were accumulated for each State or resource area from the latest FIA report. These volumes were then converted to weight using average weight values. These average values were computed by taking wood density information by species, weighted by the proportion of total inventory volume by that species. This information is displayed in the appendix of this report, for green and dry weights. Following calculation of inventory weight, bark was added to the bole by applying bark factors, also shown in the appendix. This value, wood and bark, is reported as total bole weight.

The next step was to add the top to the bole. Top factors were derived from tariff table used by FIA at the PNW Station. Evaluation of the relationship of top to main portion of the bole showed very little variation by species. Therefore, average values for all species were applied to the bole weight figures. These values are shown in the appendix.

Weight of all branches was then added to the total weight of the entire bole. This was accomplished by applying branch factors from published sources to the bole weight figures. Many sources were used to develop the branch factors. Where different sources gave widely different values for branches an average value was chosen. This, of course, was the norm rather than the exception. A summary of branch factors is shown in the appendix.
Methods Area Determination

Growing Stock Trees

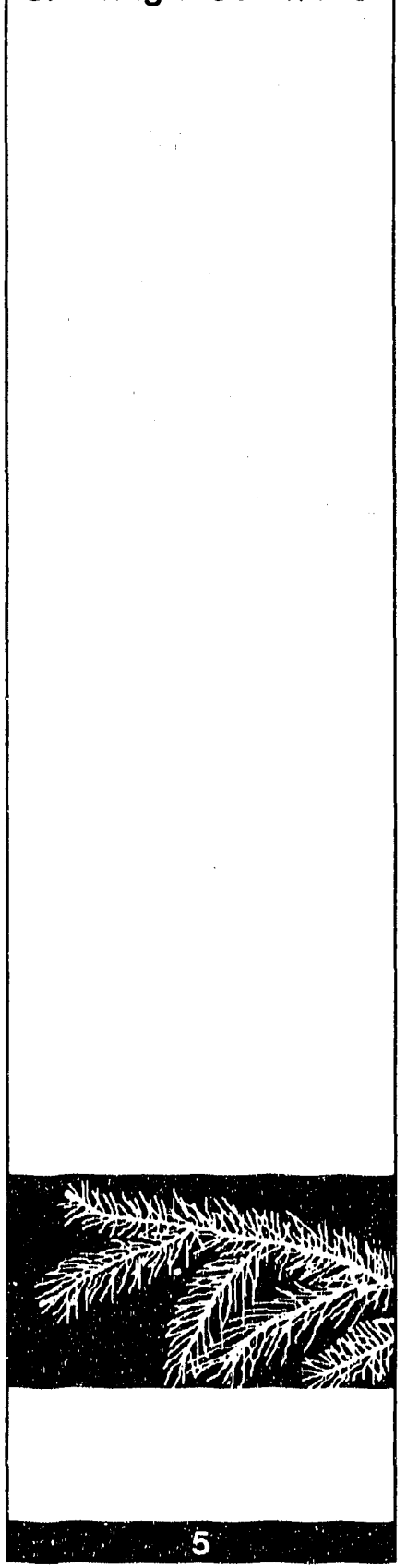




\section{Small Trees}

\section{Cull Trees}

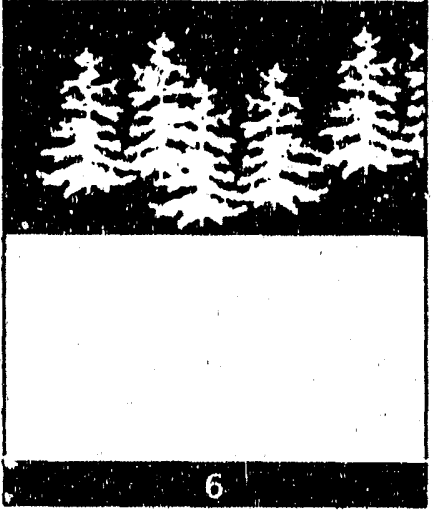

The general formula for this process is shown below:

total tree weight $=$ (inventory bole vol.) $\times$ (ave. wood density/2000 lbs.)

$$
\begin{aligned}
& \times(1.0+\text { bark factor }) \times(1.0+\text { top factor }) \times(1 . C+ \\
& \text { branch factor })
\end{aligned}
$$

These calculations were completed by species and diameter class in order to generate the desired tables shown in this report. Proportions from FIA inventory repoing were used when othel tistributions of biomass were required, such as for ownership.

Total biomass for sniall trees (1.0 to 4.9 inches, $\mathrm{dbh}$ ) was developed by applying ayarage tree weights to total number of trees from FIA r. Orts. For some areas the number of small trees was not identified in the FIA reports. For these areas total weight taken trom a 1980 biomass assessment (U.S. Department of Agriculture 1981a). The date of inventory for these cases was similar, thus the expected number and weight of small trees shouki be approximately the same for the fwo time periods. Average weight of small treos, by diameter class and species, is shown in the appendix. Dry weights wery computed using dry/green weight ratios from the density values also shown in the appendix.

Volume of cull trees (net) was taken from the respective FIA inventor, report for each arca. The bole weight of these trees was computed in the same manner as for growing stock trees. The proportion of other biomass, top and branches, was computed using the proportions developed for the 1980 compilation (U.S. Depjarment ul Agriculturo 1981a). An assumption was made that the propontion of crown weight to bole weight has not changed since the 1980 figures were computed. 
Weight of salvable dead trees was computed by converting FIA inventory volume to dry or green weight using the average density values noted above. Only bole weight is shown for salvable dead trees. ${ }^{\wedge} n$ assumption was made that bark and brarch material does not exist. This is of course not entirely true, but no data exists to determine the amount of the material that is present. Because of this, figures given in this report underestimate the actual weight or salvable dead trees by an unknown amount.

'-ogging residue information in this report iricludes only pieces that are at least 3.0 inches in diameter and 1.0 foot long. Other material, primarily crowns of trees harvested, has not been estimated on a regional basis. The unlume of additional residue ir, the smaller sizes could be in excess of 20 dry tons per acre (Maxwell and Ward 1976). Estimates of logging residue volume and weight were derived from published data for each area (Howard 1981a, 1981b; Howard and Fiedler 1984; Howard and Setzer 1989). Information in Tables 18, 19, 21, 22, and 23 was taken directly from these reports. Weight information in Table 20 was derived by applying dry weight values to cubic foot logging residue volumes. Total residue weight for each area (Table 12) was computed by multiplying the average weight of residue per 1,000 board feet of timber harvest by the total board foot volume of timber harvest. This was done for each ownership/harvest method represented in each area. Total weight for the area was tine sum of these computations.

Energy values, Btu's, were computed for portions of the forest biomass of the 5 State area that were considered to be the most likely conversion opportunities. This includes crowns of growing stock trees, small trees, cull trees, and logging residue. No information is given on the amount of these sources that might actually be available for energy conversion, nor is $t /$ sumption made that all of this material should in fact be used for that purpose. Energy values, expressed in Btu's per pound, vary considerably by species and type of

Salvable Dead Trees

Logging Residue

Energy Vialues 
material (wood and bark). No attempt was made to determine the actual energy value of each source of biomass; weighing specie values by proportion of wood and bark. Rather, an average value of 8500 Btu's frer bone dry pound was used to compute emergy values. This amounts iv 17 million Btu's per bone dry ton.

This figure . apresents an estimate of the higher heating value of each biomass source. Actual recoverable energy values depend on moisture content and efficiencies of conversion equipment. The information given in this report is intended to provide relative energy values for each area. Actual opportunities for converting woody biomass to energy must be made on a site specific basis, utilizing detailed information for the area and sources considered as supply for the facility under siudy. National energy consumption is frequently shown in terms of quads ( $1 \times 1015$ Btu's). This measure is used to judge the relative significance a particular source of energy contributes, or might contribute, to National or regional supplies. 
As noted earlier this area of the United States contains a large share of the Nation's timber resource. This resource occurs on a land arc a of nearly 80 million acres; about 30 percent of the total land area of the five states. The area of timberland by resource area is shown in table 1. As this data shows the propoltion of timberland varies consioerably between the 11 resource areas. The proportion ranges from 16 percent in Montana, to 80 percent in southwest Washington (see figure 3). In general the area west of the Cascade mountain range has a much higher proportion of timberland than the areas to the east. Just over 40 percent of the Southeast Alaska area is covered by timberiand.

Table 1. Total land area by State, resource area, and land class

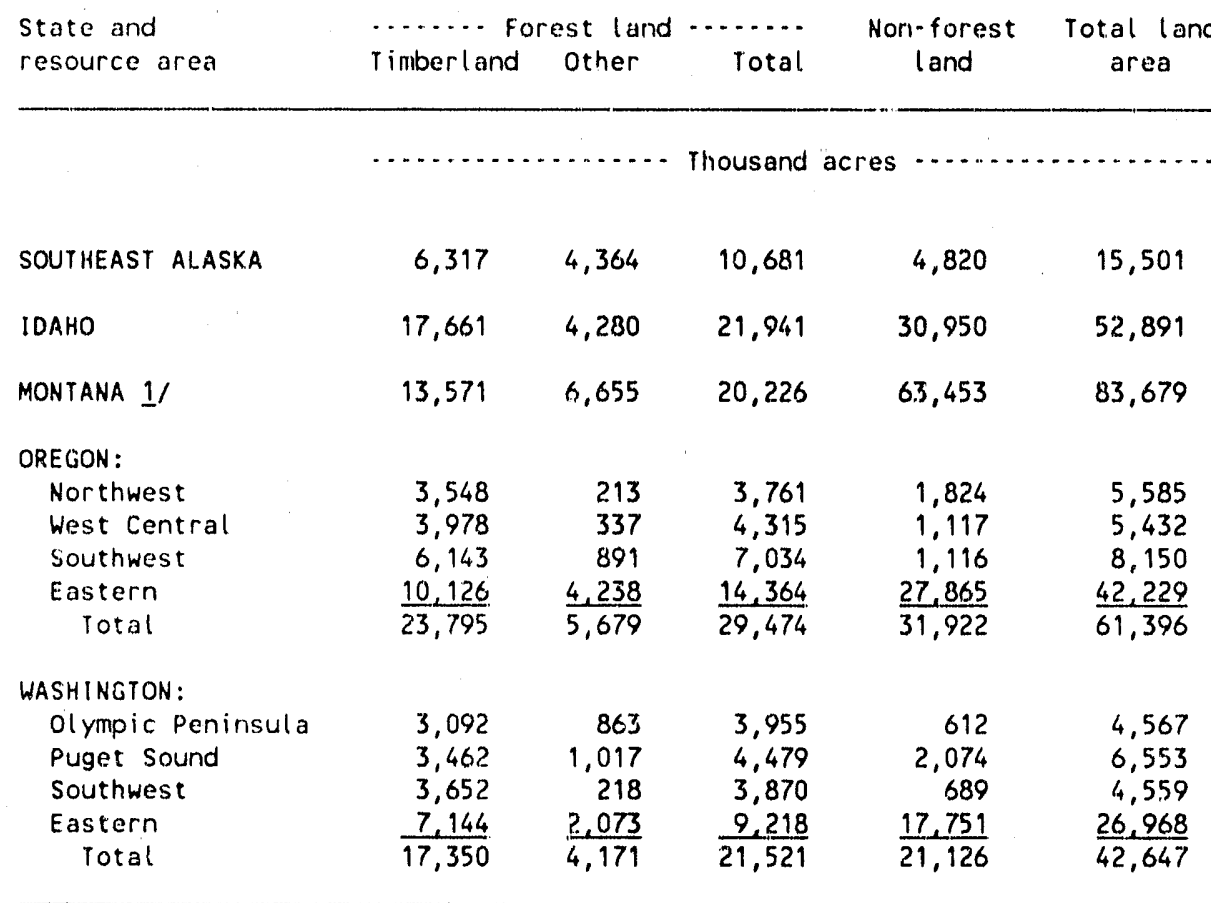

1/Does not include $8.1 \mathrm{mill}$ ion acres of land for which no data was available. (see Green, O'Brien, and Schaefer 1985)

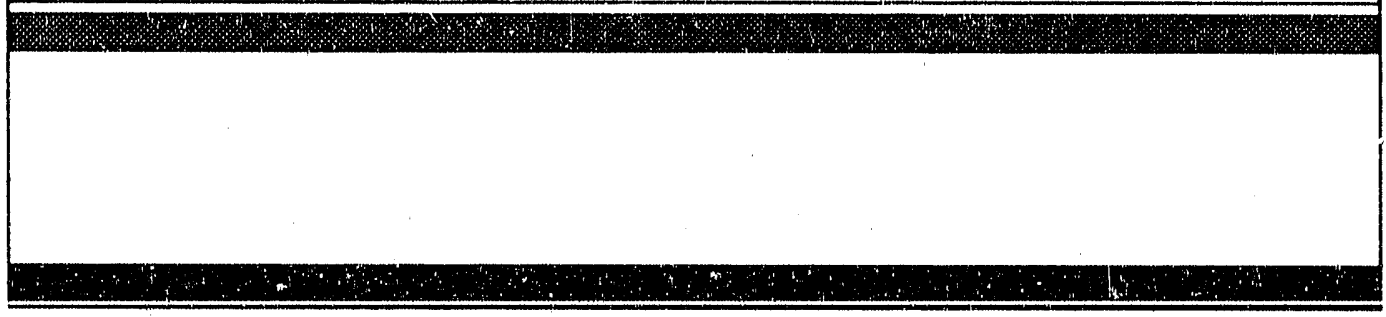

Area Analysis 


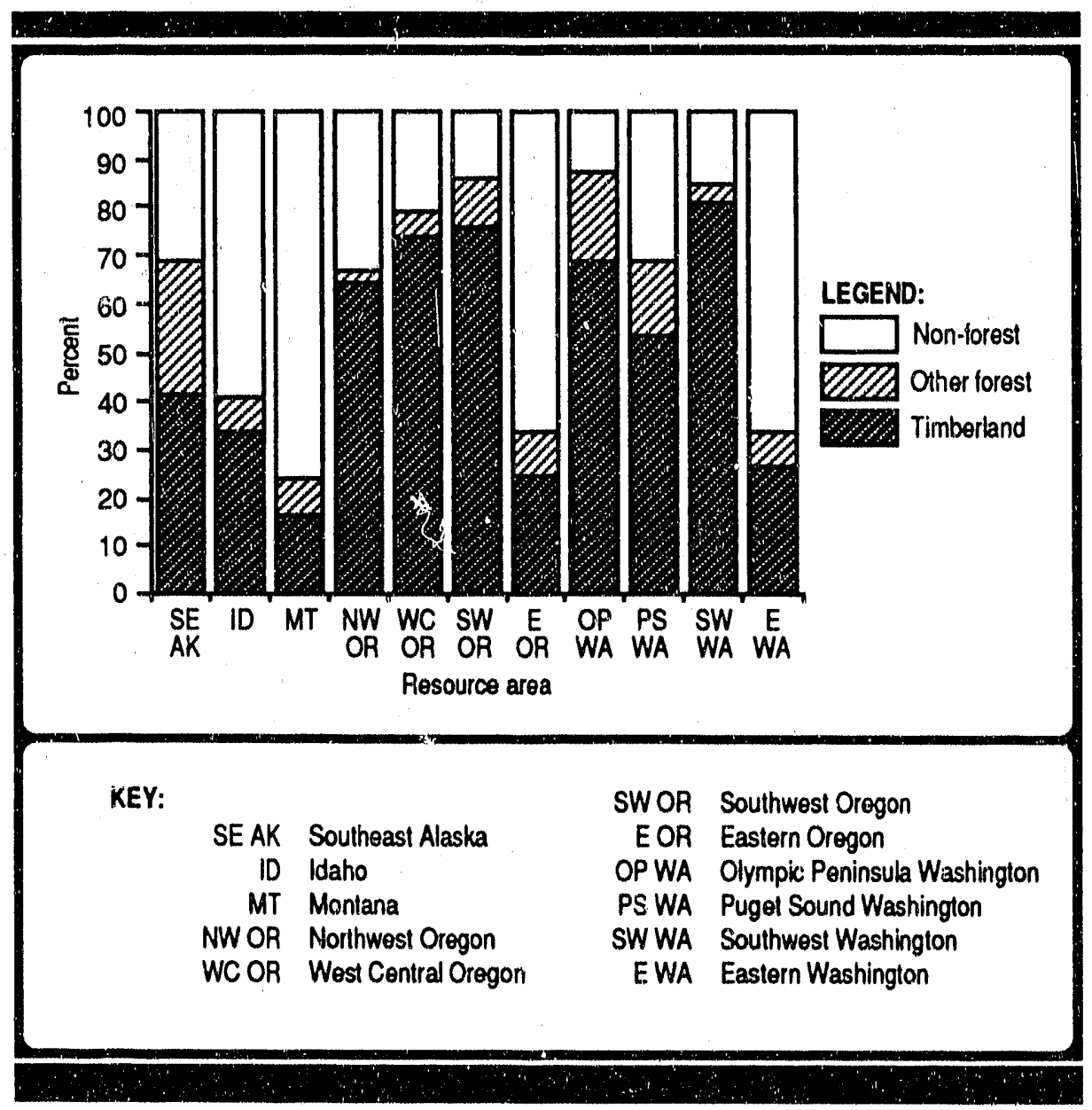

Figure 3: Total land area by classification by resource area

A considerable amount of timber exists on Other Forest Land throughout the 5state area. The proportion of this land classification ranges from 4-28 percent of the total land base. Timber on this land is not reeadiliy available for harvest, either by being withdrawn from production by statute, or by nature of its quality, species, or remoteness. A certain amount of wood from these lands might enter the energy market in the future. No effort has been made to estimate these quantities in this report. Future biomass assessment, however, may incorporate this iniormation. 
Of the $\mathbf{8 0}$ million acres of timberland, roughly two-thirds is in public ownership (table 2). National Forests account for about 55 percent of the total, with Bureau of Land Management and State lands being the next largest owner groups. As shown in figure 4 , the highest proportion of public ownership is in southeast Alaska (93 percent) and the lowest in southwest Washington (41 percent). Western Washington has the highest percentage of land in private ownership of all the areas, an average of about 58 percent, over 60 percent of which is owned by forest industries. Other Private holdings are highest in Montana and the Puget Sound area of Washingion. Ranches and farms are a major component of this ownership in Montana, while miscellaneous private owners predominate the Puget Sound area.

Table 2. Area of timberland by State, resource area, and ownership

\begin{tabular}{|c|c|c|c|c|c|}
\hline $\begin{array}{l}\text { State and } \\
\text { resource area }\end{array}$ & $\begin{array}{l}\text { National } \\
\text { Forest }\end{array}$ & $\begin{array}{l}\text { other } \\
\text { public }\end{array}$ & $\begin{array}{l}\text { Forest } \\
\text { industry }\end{array}$ & $\begin{array}{l}\text { Other } \\
\text { private }\end{array}$ & $\begin{array}{c}\text { All } \\
\text { Ownerships }\end{array}$ \\
\hline SOUTHEAST ALASKA & 5,649 & 200 & $\cdots$ & 468 & 6,317 \\
\hline IDAHO & 12,808 & 1,635 & 1,178 & 2,040 & 17,661 \\
\hline MONTANA & 8,162 & 759 & 1,601 & 3,049 & 13,571 \\
\hline $\begin{array}{l}\text { OREGON: } \\
\text { Northwest } \\
\text { West Central } \\
\text { Southwest } \\
\text { Eastern } \\
\text { Total }\end{array}$ & $\begin{array}{r}936 \\
1,630 \\
2,019 \\
7,046 \\
11,631\end{array}$ & $\begin{array}{r}802 \\
551 \\
1,509 \\
\quad 606 \\
3,468\end{array}$ & $\begin{array}{l}1,042 \\
1,097 \\
1,641 \\
\frac{1}{5,567} \\
, 347\end{array}$ & $\begin{array}{r}768 \\
700 \\
974 \\
907 \\
3,349\end{array}$ & $\begin{array}{r}3,548 \\
3,978 \\
6,143 \\
10,126 \\
23,795\end{array}$ \\
\hline $\begin{array}{l}\text { WASHINGTON: } \\
\text { Olympic Peninsula } \\
\text { Puget Sound } \\
\text { Southwest } \\
\text { Eastern } \\
\text { Total }\end{array}$ & $\begin{array}{r}538 \\
835 \\
1,081 \\
2,907 \\
5,361\end{array}$ & $\begin{array}{r}758 \\
629 \\
427 \\
1,977 \\
3,791\end{array}$ & $\begin{array}{r}1,215 \\
998 \\
1,495 \\
880 \\
4,588\end{array}$ & $\begin{array}{r}581 \\
1,000 \\
649 \\
1,380 \\
3,610\end{array}$ & $\begin{array}{l}3,092 \\
3,462 \\
3,652 \\
7,144 \\
17,350\end{array}$ \\
\hline
\end{tabular}



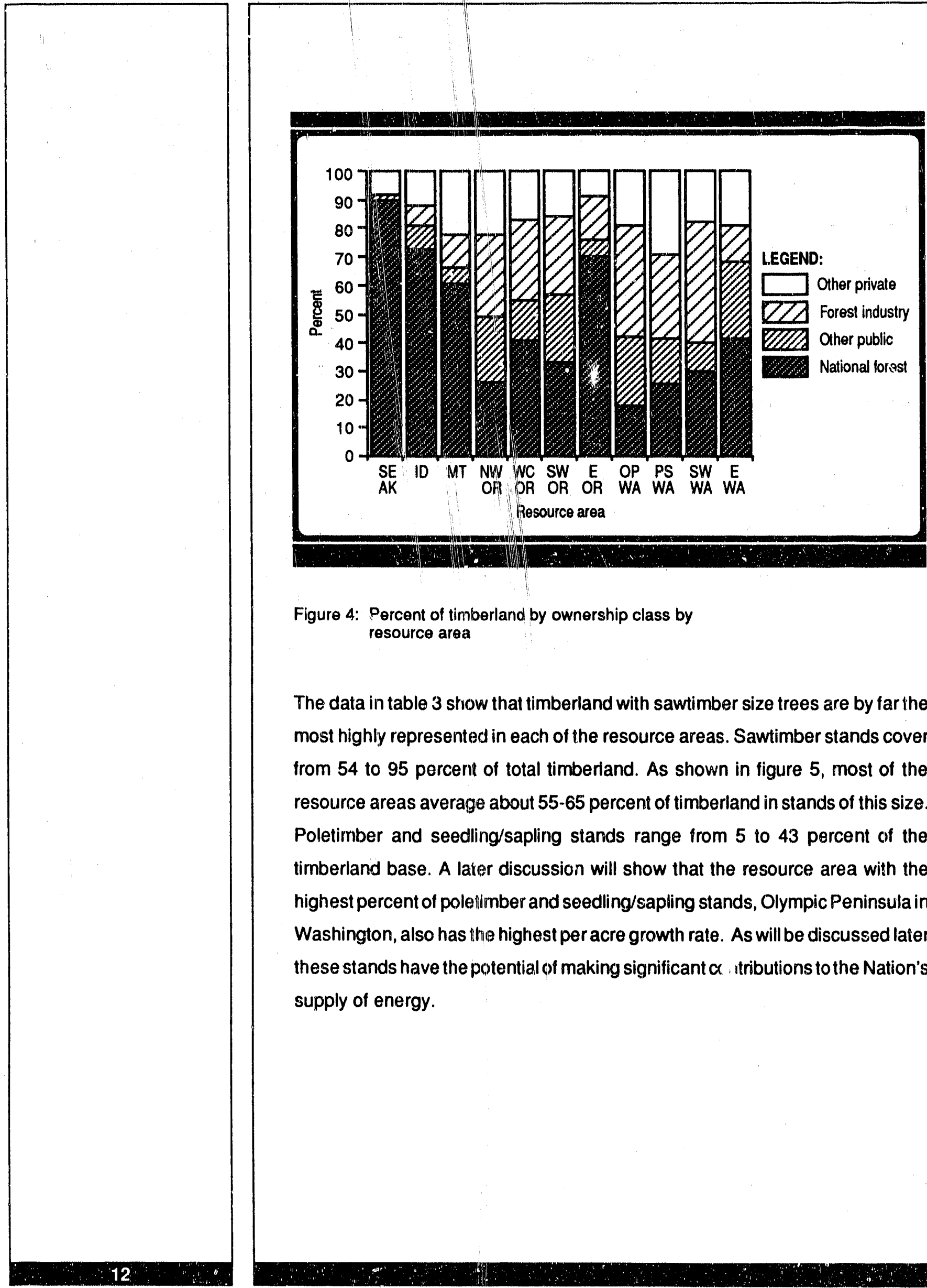

Figure 4: Percent of timberland by ownership class by resource area

The data in table 3 show that timberland with sawtimber size trees are by far the most highly represented in each of the resource areas. Sawtimber stands cover from 54 to 95 percent of total timberiand. As shown in figure 5 , most of the resource areas average about 55-65 percent of timberland in stands of this size. Poletimber and seedling/sapling stands range from 5 to 43 percent of the timberland base. A later discussion will show that the resource area with the highest percent of poletimber and seedling/sapling stands, Olympic Peninsula in Washington, also has the highest per acre growth rate. As will be discussed later these stands have the potential of making significant $\alpha$, itributions to the Nation's supply of energy. 
Table 3-Area of timberland by State, resource area, and stand-size class.

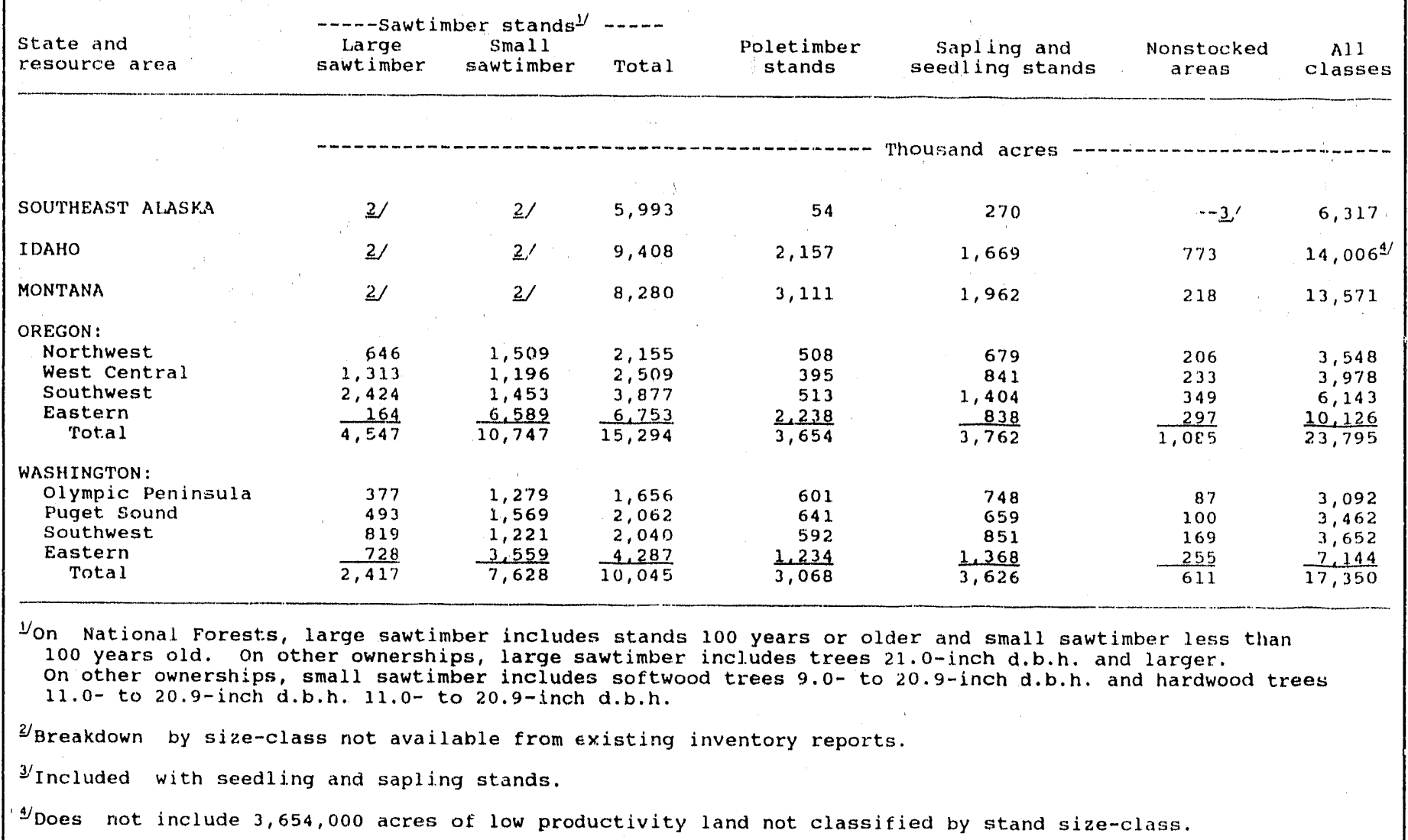

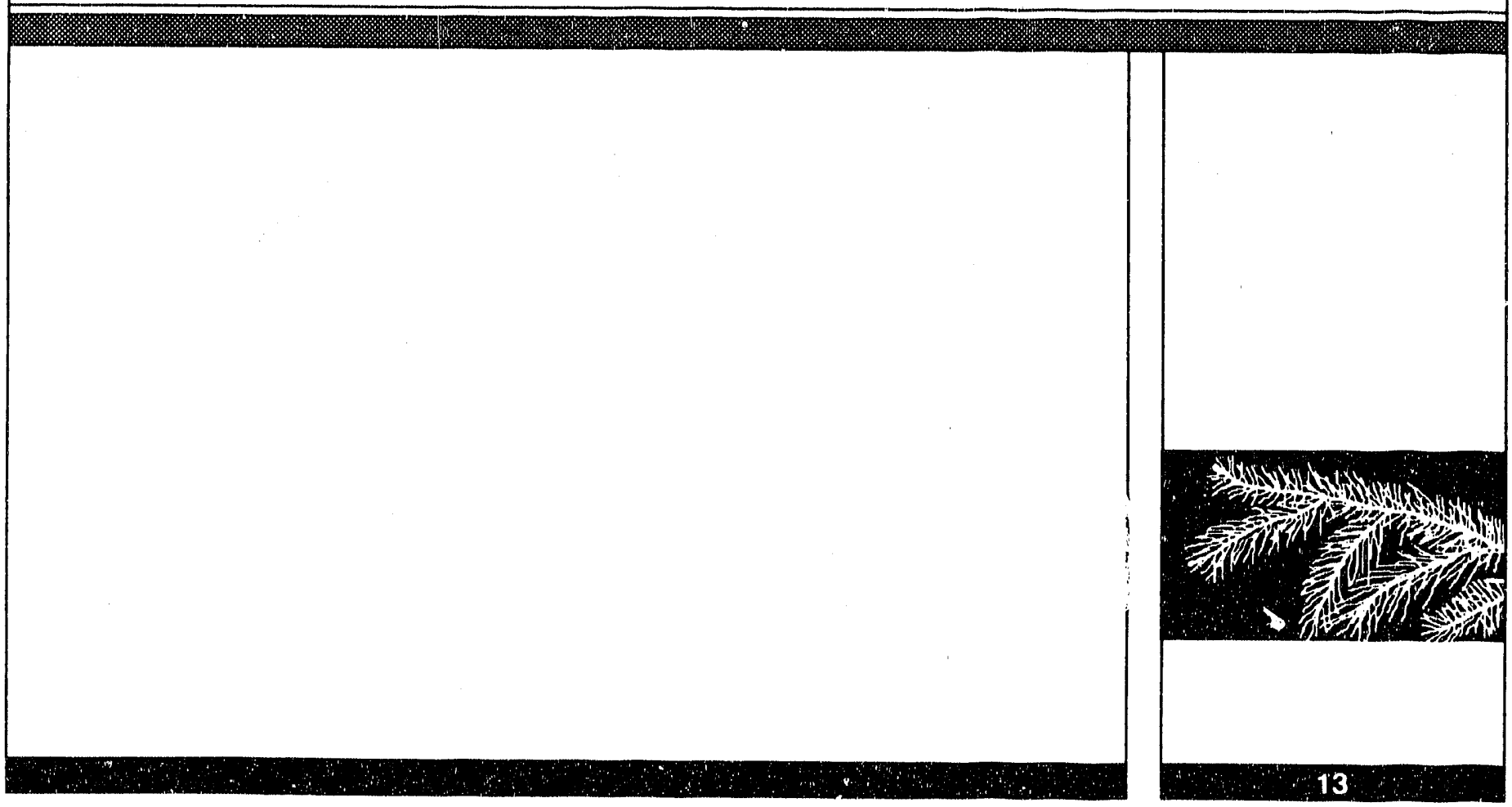




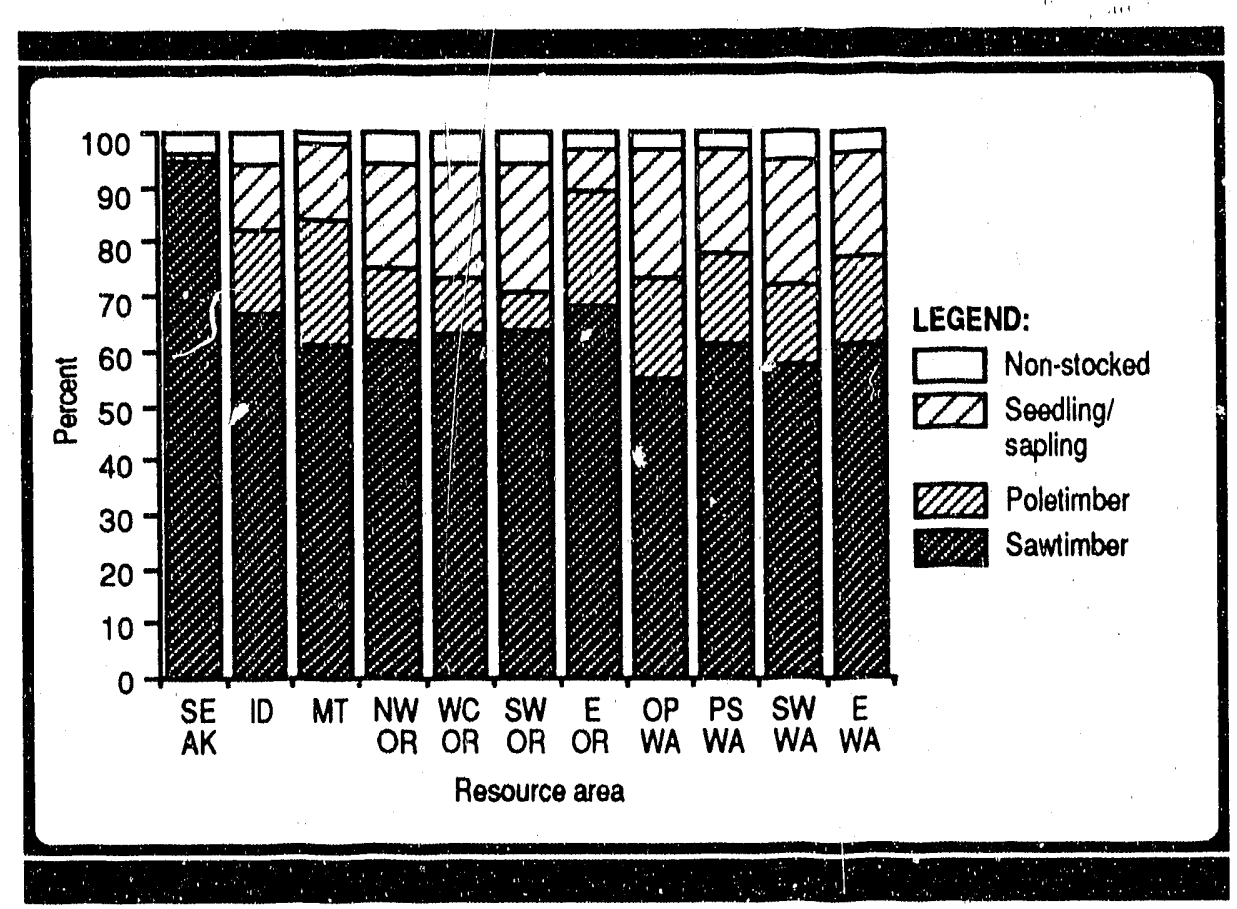

Figure 5: Percent of timberland by stand-size class by resource area

Douglas-fir is the predominate forest type in the 5-State area (see table 13, in appendix). Only in southeast Alaska (hemlock/spruce), and Montana and eastern Oregon (pines) do other species cover a higher proportion of the timberland. The proportion of major forest types is depicted in figure 6 . Stands of red alder cover eccur in many of the resource areas. Table 13 shows red alder to be well represented in 6 of the resource areas, ranging from 6-20 percent of the timberland base. Through the years red alder has been underutilized, in comparison to its inventory. While there has been a recent upswing in interest in red alder, this type represents a potential major contributor of wood energy. It should be noted that forest type classification depicts the predominate species in a stand. Other species do occur in many of these stands, and are often not used to the same extent as the major species. Agood example of this is small hemlock in Douglas-firstands, and lodgepole pine in ponderosa pine type. A viable energy market might encourage better utilization of these trees. 


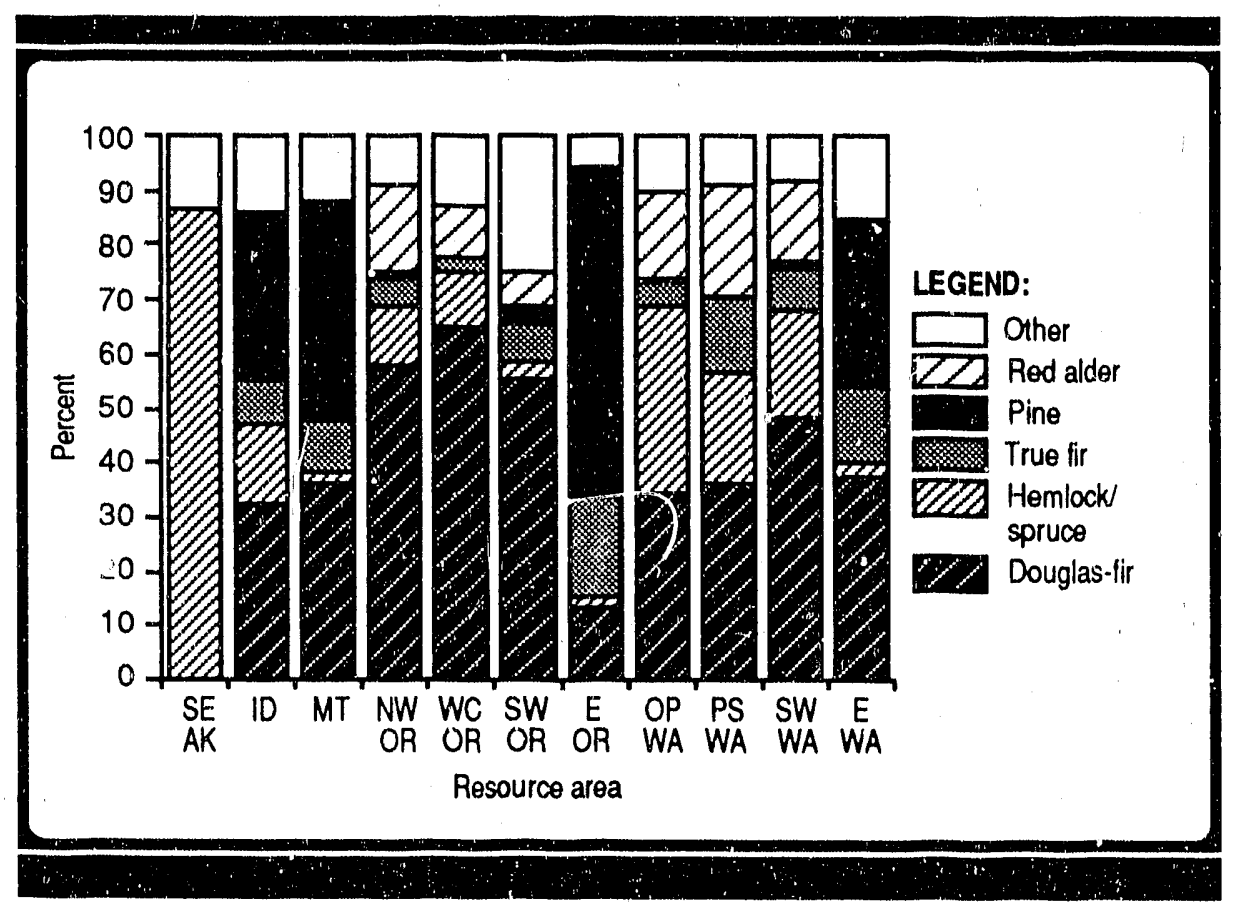

Figure 6: Percent of timberland by forest type by resource area

Table 14 (in the appendix) shows area of timberland by cubic-foot site class. This classification is an attempt to define the basic growth capability of a stand. Stands with the highest potential can produce in excess of 225 cubic feet per acre per year. Those with the lowest potential produce less than 49 cubic feet per acre per year. Stands capable of producing 120 cubic feet or more per year are considered as sites with good growth potential. The data in table 14 show that almost 30 percent of the timberland is capable of producing 120 cubic feet per acre per year. These stands are not uniformly distributed. Roughly 72 percent of stands with this growth potential are located in the western parts of Oregon and Washington. Data on site class are not available for southeast Alaska, thus the above figures do not include the Alaska acreage.

Stands with a relatively high level of productivity, are aiso the stands that produce high quantities of total biomass. On the other hand, stands with lower 
The Blomass

Resource

productivity, like lodgepole pine. often represent a good potential for wood energy due to the smaller size and lower quality tree that occurs on the site. Trees with these characteristics are frequently not highly demanded for conventional products. Thus, the proportion of biomass in these stands available for energy is relatively high, in some cases nearly 100 percent. These data are useful for determining the relative growth potential of stands. As the examples above indicate, however, growth potential is not directly correlated with wood energy supplies.

The estimated total quantity of woody biomass for the 5-State area is 4.425 billion bone dry tons (table 4). As noted earlier total tree biomass refers to the above ground weight of a tree above a 1.0 foot stump, and exclusive of foliage; included are small trees, those from 1.0 - 4.9 inches in diameter; cull trees; and salvable dead trees. The equivalent green weight (containing water, in natural conditions) of the woody biomass is just under 9.3 billion green tons (table 5 ). Current figures for the U.S. are not available, but the total green weight of the 5State area roughly compares to 13.9 billion green tons for a 13 state area in southeastern U.S. (Waldrop and Brooks 1984). About 44 percent of the 4.425 billion dry tons occurs in western Oregon and western Washington. The remainder is divided fairly evenly among the other five areas (southeast Alaska has the next highest total, 14 percent). 
Table 4. Total dry weight of above ground biomass on timberland by State, resource area, and class of timber.

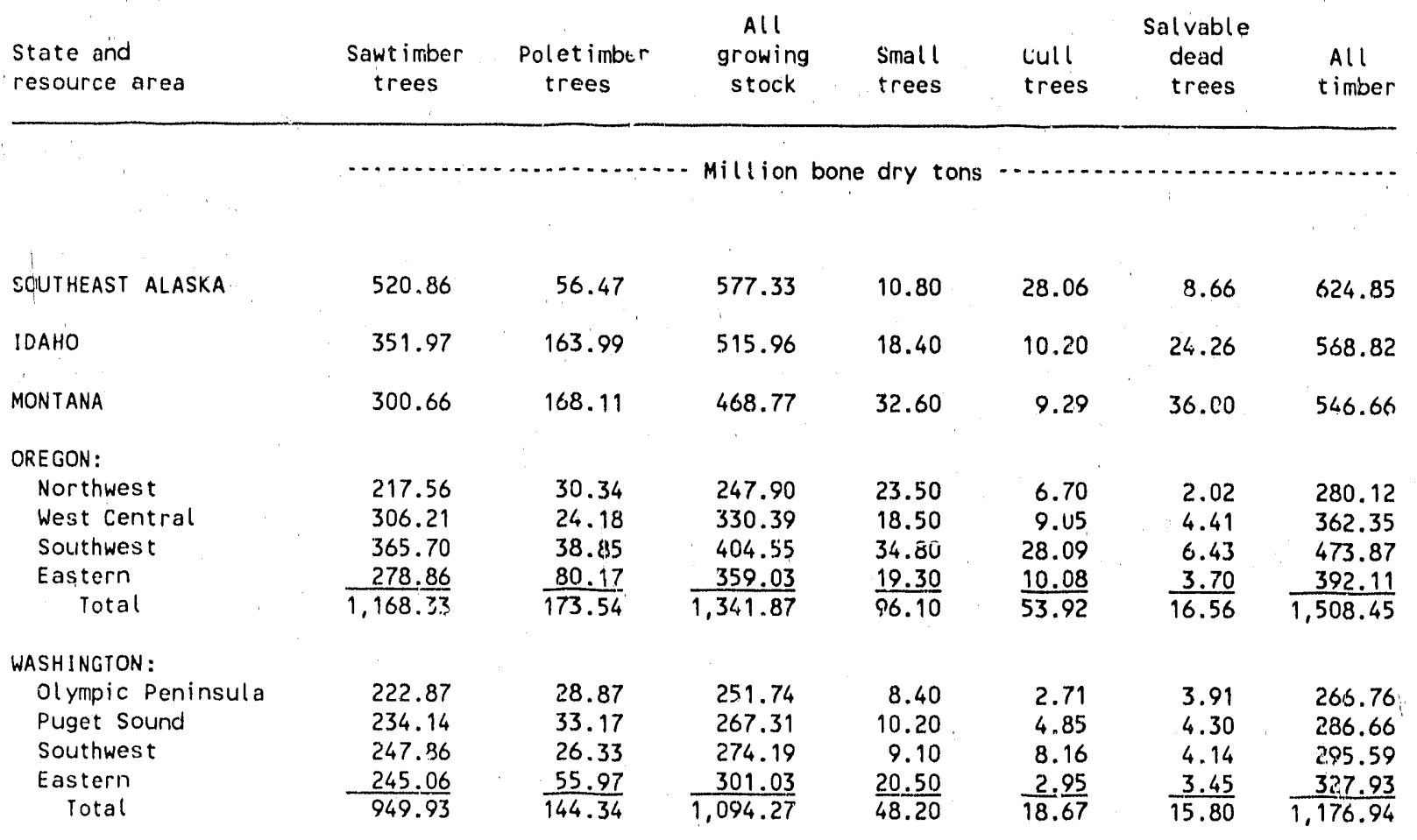
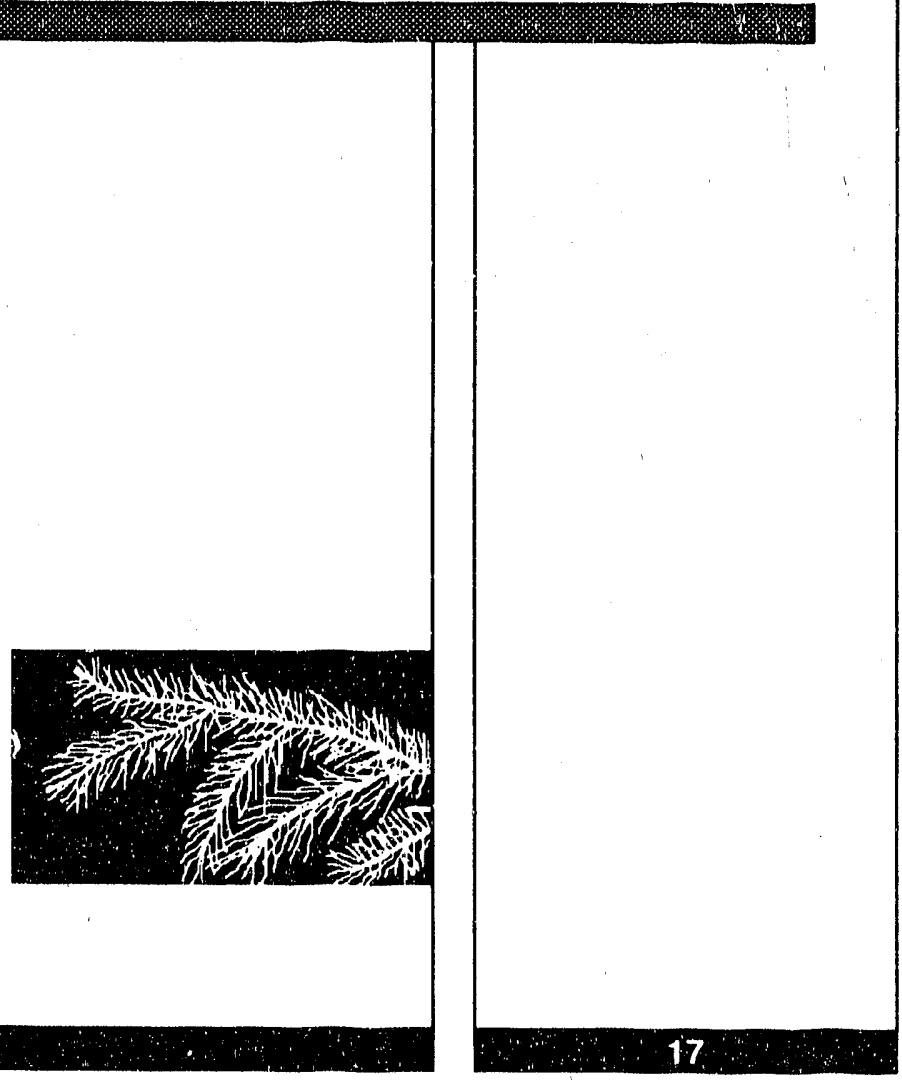


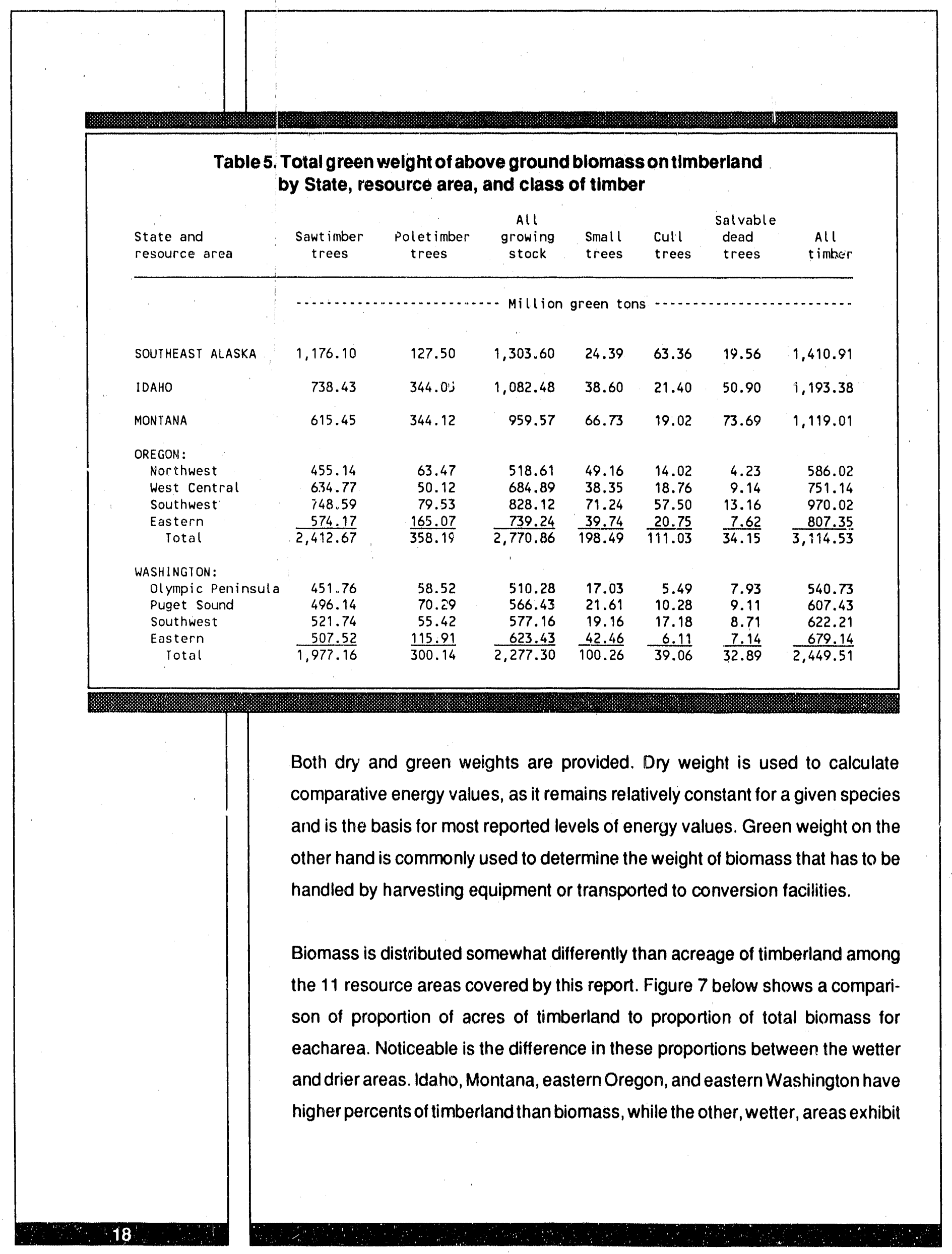


the opposite situation. Greater quantities of biomass may represent greater opportunities for energy conversion, although this is not always the case.

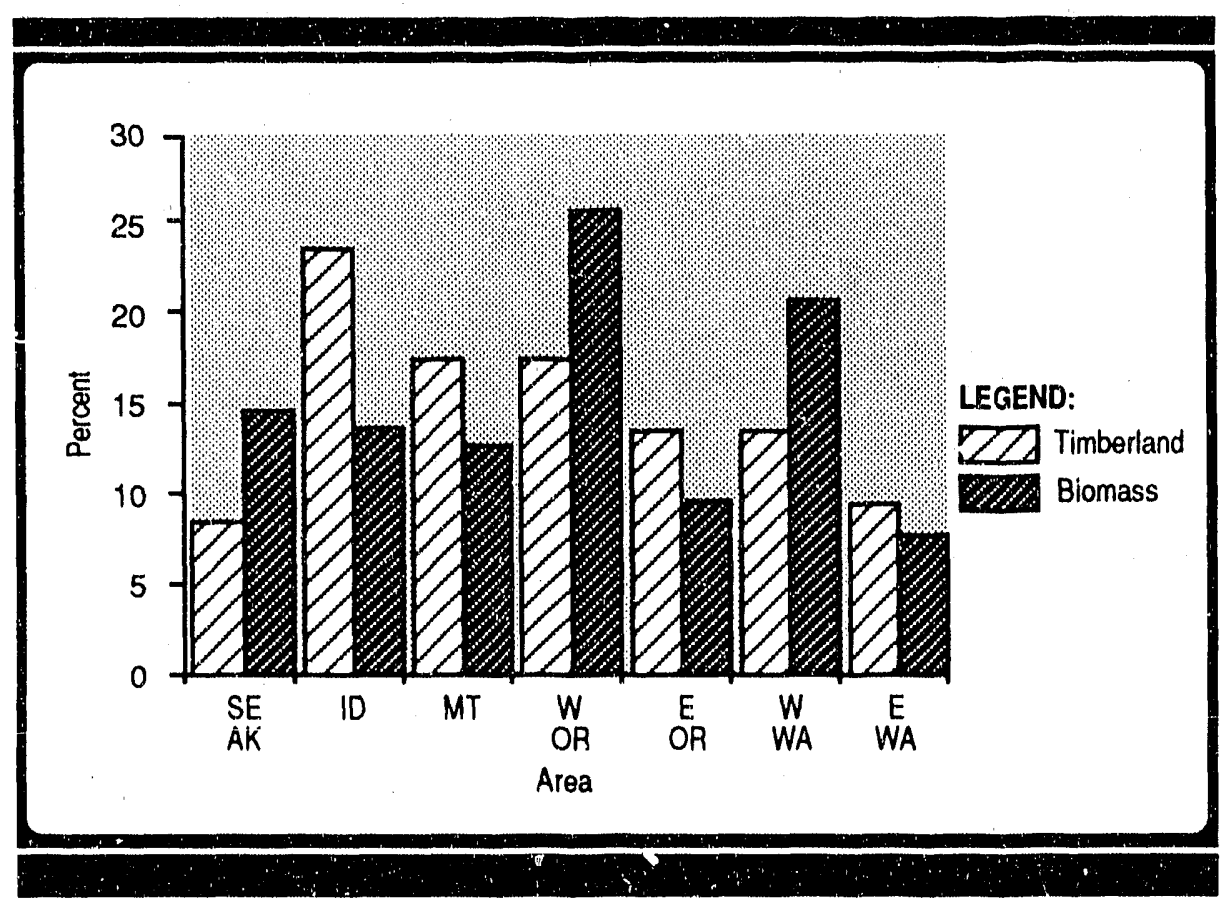

Figure 7: Proportion of total timberland compared to proportion of total biomass by area

As might be expected the largest portion of the total is represented by sawtimber trees, those greater than 11.0 inches in diameter. Figure 8 shows the distribution of total biomass by class of timber. While sawtimber trees account for the largest share of the total, the distribution by class of timber is not uniform when comparing the different areas. Montana, for example differs considerably from the other areas. The sawtimber portion in Montana is the lowest among the areas, at 55 percent, while poletimber trees account for 31 percent, highest among the 11 areas. Also notable is the relatively high proportion of biomass in salvable dead trees. This is most likely attributable to the high incidence of beetle killed lodgepole pine trees. Southeast Alaska on the other hand has 83 percent of its biomass in sawtimber trees and only 9 and 2 percent respectively in poletimber and seedling/sapling trees. 


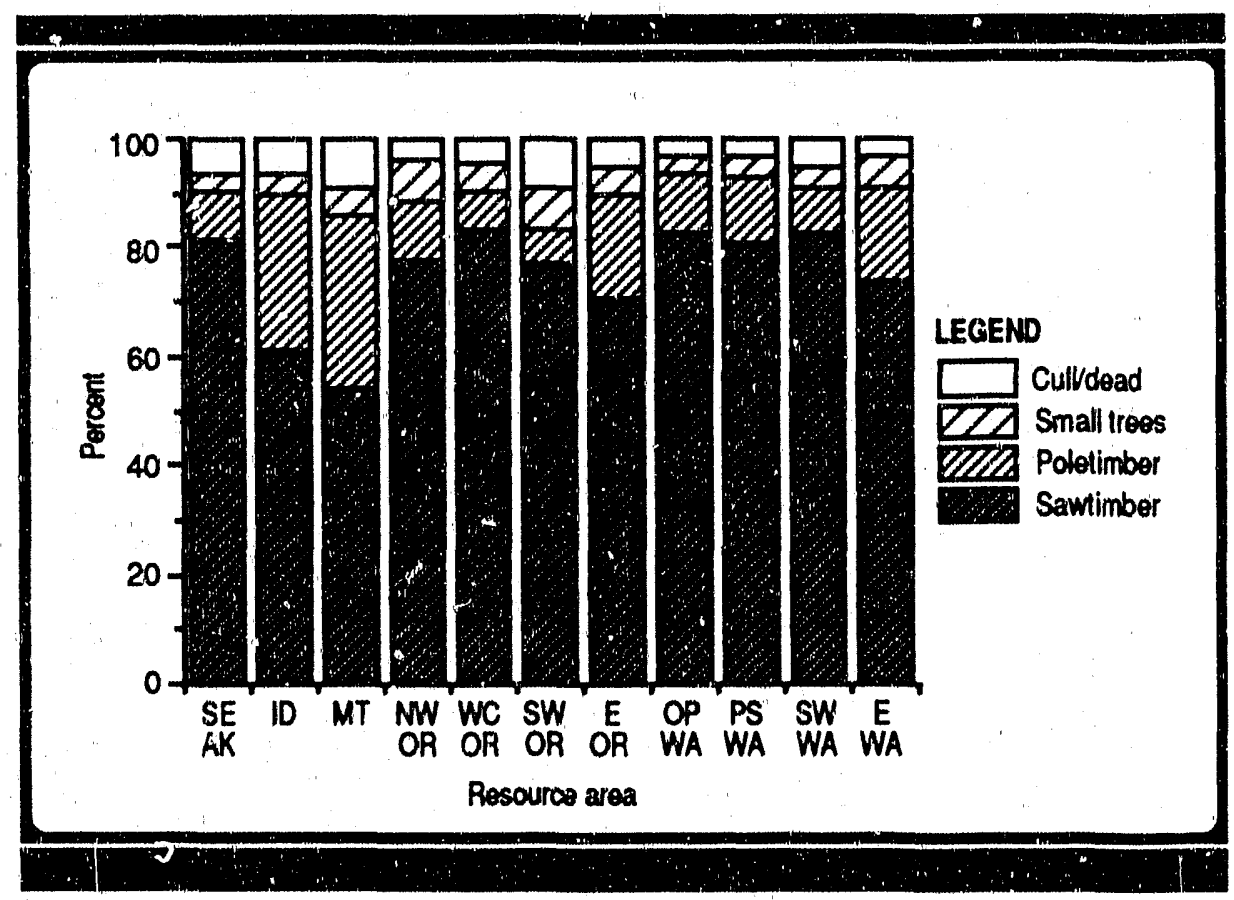

Figure 8: Percent of total biomass by stand-size class by resource area

Generally speaking these proportions give a clue to the sources of woody biomass that may be available for energy. Sawtimber stands are the source of most of the wood harvested in the 5-State area. Thus, it is these stands that offer opportunities to increase utilization during regular harvest operations. Poletimber and some of the larger seedling/sapling stands offer different opportunities. Specifically, many land managers would like to enter these stands at an earlier age to accomplish silvicultural objoctives. Thinning to increase growth on remaining trees is an example. Costs of doing this work are high, and frequently there is no income to offset these costs. Having a market for this material, possibly for energy, would offer the incentive needed to increase the level of these activities. A very active energy market might attract a significant amount of biomass from these stands, beyond that left to protect other resource values. 
The proportion of total biomass in small, cull, and salvable dead trees is relatively small in all areas, ranging from 5-15 percent. These classes of timber do offer some opportunity for energy conversion, usually in conjunction with regular or salvage harvest operations. Cull and dead trees are usually scattered throughout the forests, the exception being trees killed by fire or insects and diseases. Small trees are found both as components of stands with larger trees and as entire stands, particularly following harvesting. In most situations they offer linited conversion opportunities, at least until they reach the size where thinning becomes a management alternative.

Public lands account for about three quarters of the 4 billion dry tons of woody biomass from growing siock treec (table 15, in appendix). National Forests contribute nearly 60 percent, while other public owners account for just over 16 percent. The National Forest figure is only an estimate since a breakdown by ownership is not available for southeast Alaska (at the date of the inventories used as a basis for this report). In terms of acres of timberland, National Forests in southeast Alaska account for almost 90 percent of the total. This proportion was used to clevelop the National Forest estimate noted above.

With some exceptions National Forest lands also have the highest per acre amounts of biomass, ranging from 28.52 tons per acre, dry weight, in Idaho to 123.63 tons per acre, 'jry weight, in West Central Oregon (table 6). Averages for all owners range from $29.2 i$ tons per acre, dry weight, in Idaho to 81.42 tons per acre, dry weight, in the Olympic Peninsula area of Washington. Ownership breakdown is was not available for southeast Alaska when data for this report were compiled. Thus, the range of biomass weights may differ when the Alaska data are known.

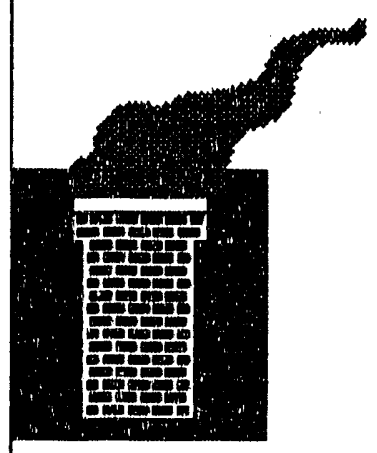




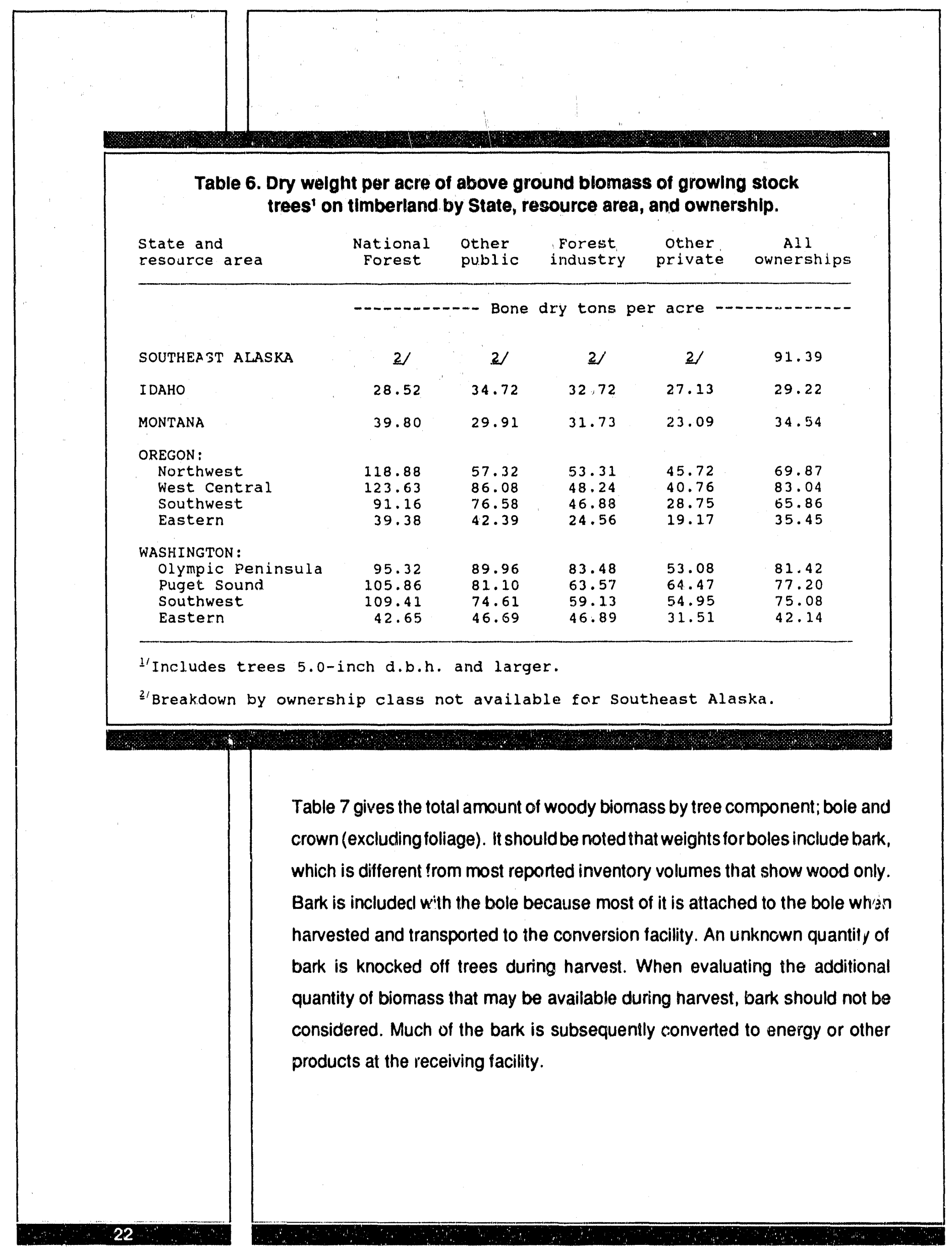




\section{Table 7. Total dry weight of above ground blomass of growing stock trees' on timberland by State, resource area, softwoods and hardwoods, and by bole and crown.}

\begin{tabular}{|c|c|c|c|c|c|c|c|c|c|}
\hline $\begin{array}{l}\text { State and } \\
\text { resource area }\end{array}$ & Bole & $\begin{array}{l}\text { Softwoods } \\
\text { Crown }\end{array}$ & Total & Bole & $\begin{array}{l}\text { Hardwoods } \\
\text { Crown }\end{array}$ & Total & Bole & $\begin{array}{c}\text { All specie } \\
\text { Crown }\end{array}$ & Total \\
\hline & $\cdots$ & & & - Mil & on bone dry & $y$ tons & & & \\
\hline SOUTHEAST ALASKA & 484.72 & 88.26 & 572.98 & 3.28 & 1.07 & 6.35 & 488.00 & 89.33 & 577.33 \\
\hline IDAHO & 421.35 & 89.31 & 510.66 & 4.34 & 0.96 & 5.30 & 425.69 & 90.27 & 515.96 \\
\hline MONTANA & 361.61 & 100.60 & 462.21 & 5.04 & 1.52 & 6.56 & 366.65 & 102.12 & 468.77 \\
\hline \multicolumn{10}{|l|}{ OREGON: } \\
\hline Nor thwest & 184.60 & 33.42 & 218.02 & 24.92 & 4.96 & 29.88 & 209.52 & 38.38 & 247.90 \\
\hline West Central & 269.49 & 39.19 & 308.68 & 18.51 & 3.20 & 21.71 & 288.00 & 42.39 & 330.39 \\
\hline Southwest & 315.85 & 46.76 & 362.61 & 35.82 & 6.12 & 41.94 & 351.67 & 52.88 & 404.55 \\
\hline Eastern & 295.83 & 62.59 & 358.42 & 0.50 & 0.11 & 0.61 & 296.33 & 62.70 & 359.03 \\
\hline Total & $1,065.77$ & 181.96 & $1 \longdiv { 2 4 7 . 7 3 }$ & $\overline{79.75}$ & $\overline{14.39}$ & 94.14 & 1.145 .52 & 196.35 & 1.341 .87 \\
\hline \multicolumn{10}{|l|}{ WASHINGION: } \\
\hline olympic Peninsula & 184.92 & 34.68 & 219.60 & 26.79 & 5.35 & 32.14 & 211.71 & 40.03 & 251.74 \\
\hline Puget Sound & 187.69 & 35.19 & 222.88 & 36.95 & 7.48 & 44.43 & 224.64 & 42.67 & 267.31 \\
\hline Southwest & 207.90 & 36.39 & 244.29 & 25.05 & 4.85 & 29.90 & 232.95 & 41.24 & 274.19 \\
\hline Eastern & 247.29 & 49.44 & 296.73 & 3.52 & 0.78 & 4.30 & 250.81 & 50.22 & 301.03 \\
\hline Total & 827.80 & $\overline{155.70}$ & $983 . \overline{50}$ & $\overline{92.31}$ & $\overline{18.46}$ & $\overline{110.77}$ & 920.11 & $\overline{174.16}$ & $1,094.27$ \\
\hline
\end{tabular}

I'Includes trees 5.0-inch d.b.h. and larger.

The proportion of crown to total tree biomass does not differ much between areas. At first thought this might not be expected. Particularly since the proportion does vary by species. From table 7 the amount of crowr in softwood trees varies from 12.7 to 21.8 percent of total biomass. The higher figure is in Montana. The next highest proportion of crown material is in Idaho, at $\mathbf{1 7 . 5}$ percent, and is closer to that of the other areas. The reason for the relatively high proportion in Montana is not known. The proportion of hardwood crown material exhibits roughly the same pattern between the areas. There is also little difference in the proportion of crown to total biomass between softwoods and hardwoods. For all areas and species crown biornass averages 16.3 percent. 
Table 8 gives the per acre values for bole and crown biomass. These are included to give some idea of concentrations of potentially available biomass. Generally speaking higher concentrations tend to be more economically attractive to potential users. This is particularly true for situations where only crown materials are currently not utilized for other products. In some cases, small diarneter lodgepole pine stands for exanrple, additional biomass in the boles may be available for energy products. In these situations the amount of crown biomass underestimates the overall potential.

Table 8. Dry welght per acre of above ground blomass of growing stock trees on timberland by State, resource area, softwoods and hardwoods, and by bole and crown.

State and ... Softwoods .... .... Hardwoods ..... -... All species ...

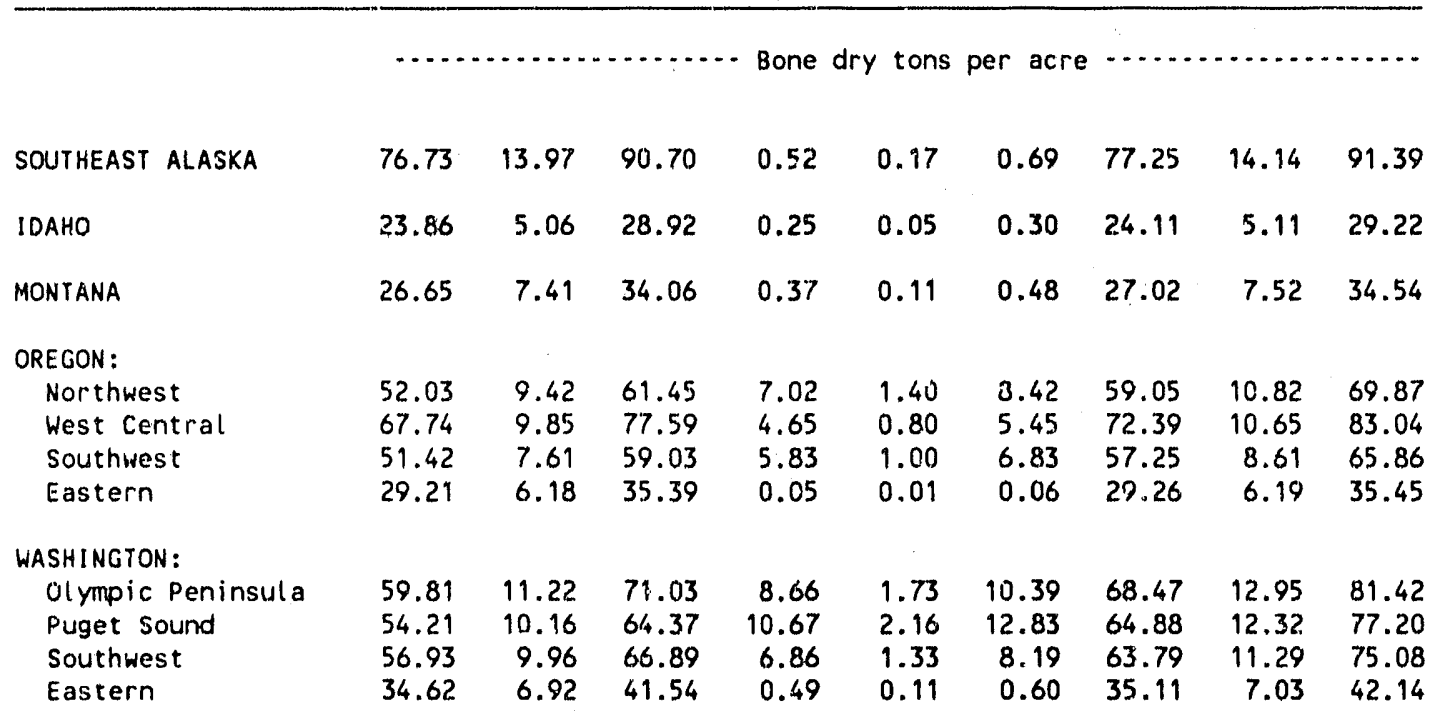


The total dry weight of biomass by species is given in table 16 (in appendix). For the most part the distribution of biomass follows the same pattern as for acreage of timberland by forest type noted earlier (see figure 6). The distribution by major species or species group is shown below.

\begin{tabular}{lcc} 
Specles & $\begin{array}{c}\text { Total blomass, } \\
\text { million BD tons }\end{array}$ & $\begin{array}{c}\text { Percent of } \\
\text { total blomass }\end{array}$ \\
\hline Douglas-fir & 1,413 & 35.3 \\
Hemlock/spruce & 1,070 & 26.8 \\
Pines & 621 & 15.5 \\
True flrs & 399 & 10.0 \\
Red aldier & 119 & 3.0 \\
Other species & 376 & 9.4 \\
Totai & 3,998 & 100.0
\end{tabular}

Distribution of the biomass by species is not uniform among the resource areas. Pines are generally found in the drier interior forests, while Douglas-fir and hemlock are found in the coastal regions. Nearly half of the hemlock/spruce type occurs in southeast Alaska, however, none of the Douglas-fir is located there. Red alder is also geographically specific. Of the 119 million dry tons, 98 percent grows in western Oregon and western Washington. As noted earlier in this report, acreage of lodgepole pine exceeds that of ponderosa pine. The same situation exists for biomass, where lodgepole accourts for 296 million dry tons and ponderosa just over 281 million dry tons. 


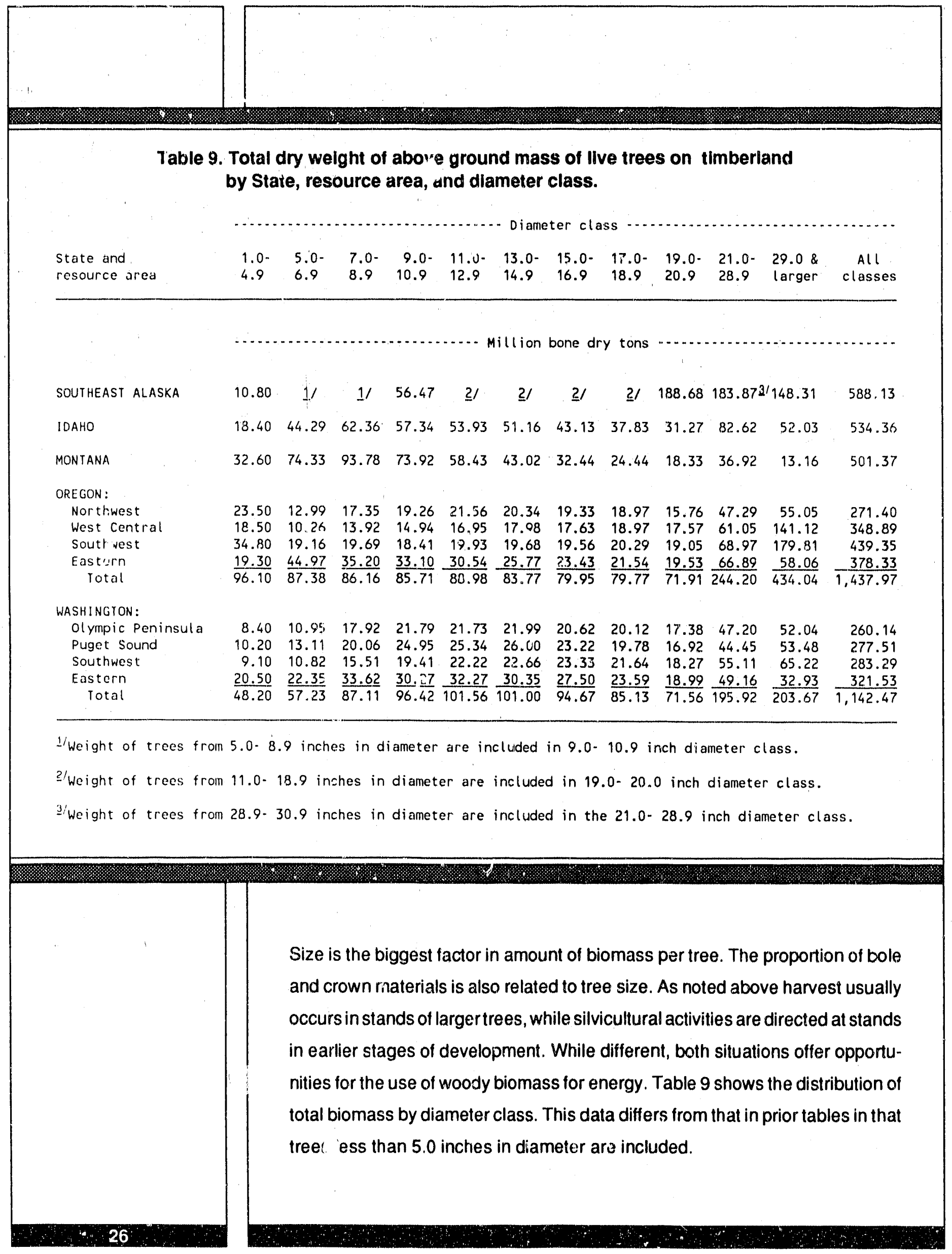


The distribution of biomass by diameter class differs considerably between the resource areas: This distribution is depicted in figure 9 . As can be seen there are some interesting differences in the sir 3 class distributions. For example, in Montana 55 percent of total biomass is in trees less than 11.0 inches in diameter. This compares to a 5-State average of only 28 percent in this same size range. There are a number of factors that lead to this size distribution, one of which is that nearly 30 percent of biomass in Montana is accounted for by lodgepole pine, usually occurring as stands of relatively small diameter trees. Just the opposite occurs in southeast Alaska where trees less than 11.0 inches account for only 11 percent of total biomass in the area. Another unique situation occurs in western Oregon. Two resource areas, Southwest and West Central, account for 38 percent of biomass in trees greater than 29.0 inches. The other area with a high proportion of biomass in this size class of tree is southeast Alaska, having about 17 percent of the 5-State total. As figure 9 sinows the interior areas tend to have a higher proportion of biomass in trees less than 11.0 inches than do the coastal areas.

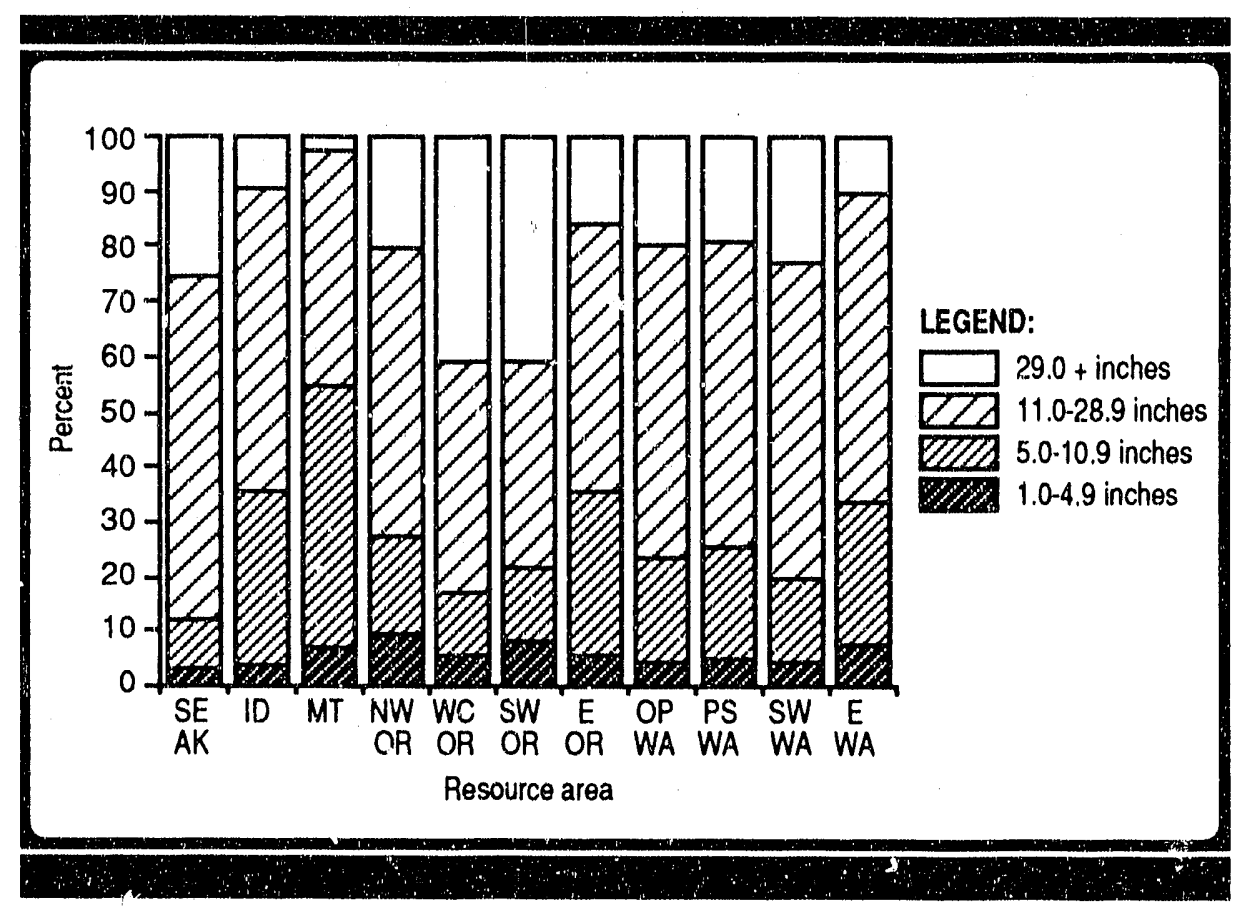

Figure 9: Biornass distribution (percent) by diameter class by resource area 


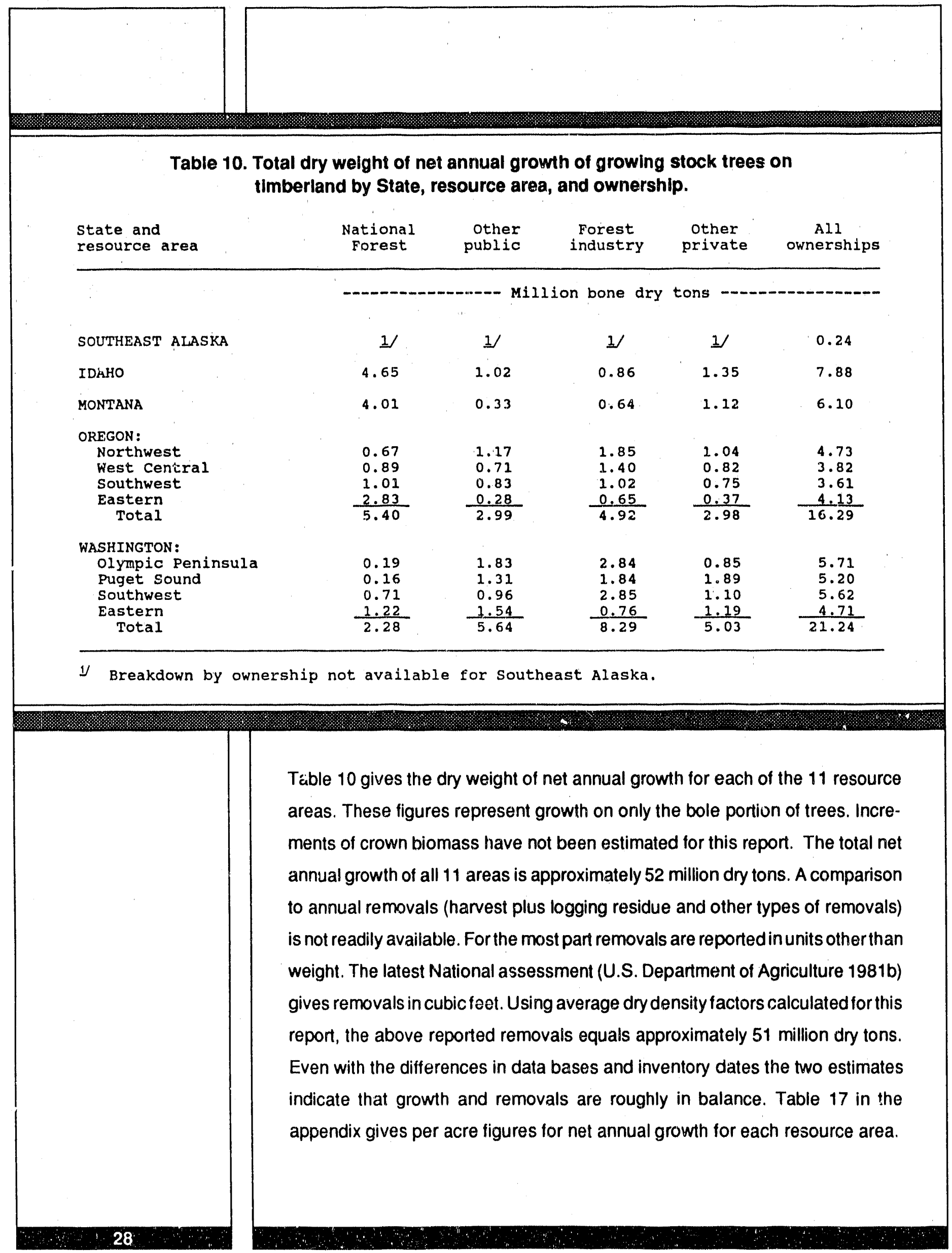


Biomass left in the woods following logging operations has been the focus of many feasibility studies since the energy crises of the mid-1970's. Aside from by-products from the forest products industries, this potential source of wood is usually considered to be the most likely to be converted to energy. Most often economics have played a key role in determining the rate at which this biomass is actually recovered for energy uses. The highest degree of recovery is currently occurring in California, spurred by construction of numerous wood fired power plants over the past 10 years. While recovery of logging residue has not been very high, lower amounts are being left now than in the past. In the future we can expect higher levels of utilization during harvest, which means less logging residue. Until that time rather large total quantities of residue will be available for potential conversion to energy. It should be noted that not all logging residue is available for energy or any off-site product. Other resource considerations, such as site productivity and wildlife habitat, will require that some amount of biomass needs to remain on site. The amount associated with these needs is not well defined at this time.

Table 11 shows the total gross and net weight of logging residue by resource area. No breakdown is given for resource areas within western Oregon and western Washington. The total net weight, 17.2 million dry tons, is about 62 percent of the total gross weight, 27.8 million dry tons. This means that the average usable coritent of the residue is 62 tons per every 100 tons. Many factors affect the economic and physical feasibility of using residual materials for energy. The relation of net to gross weight by area is shown in figure 10 . 
Table 11. Total gross and net weight (wood and bark) of logging residue by area, ownership, and harvest method.

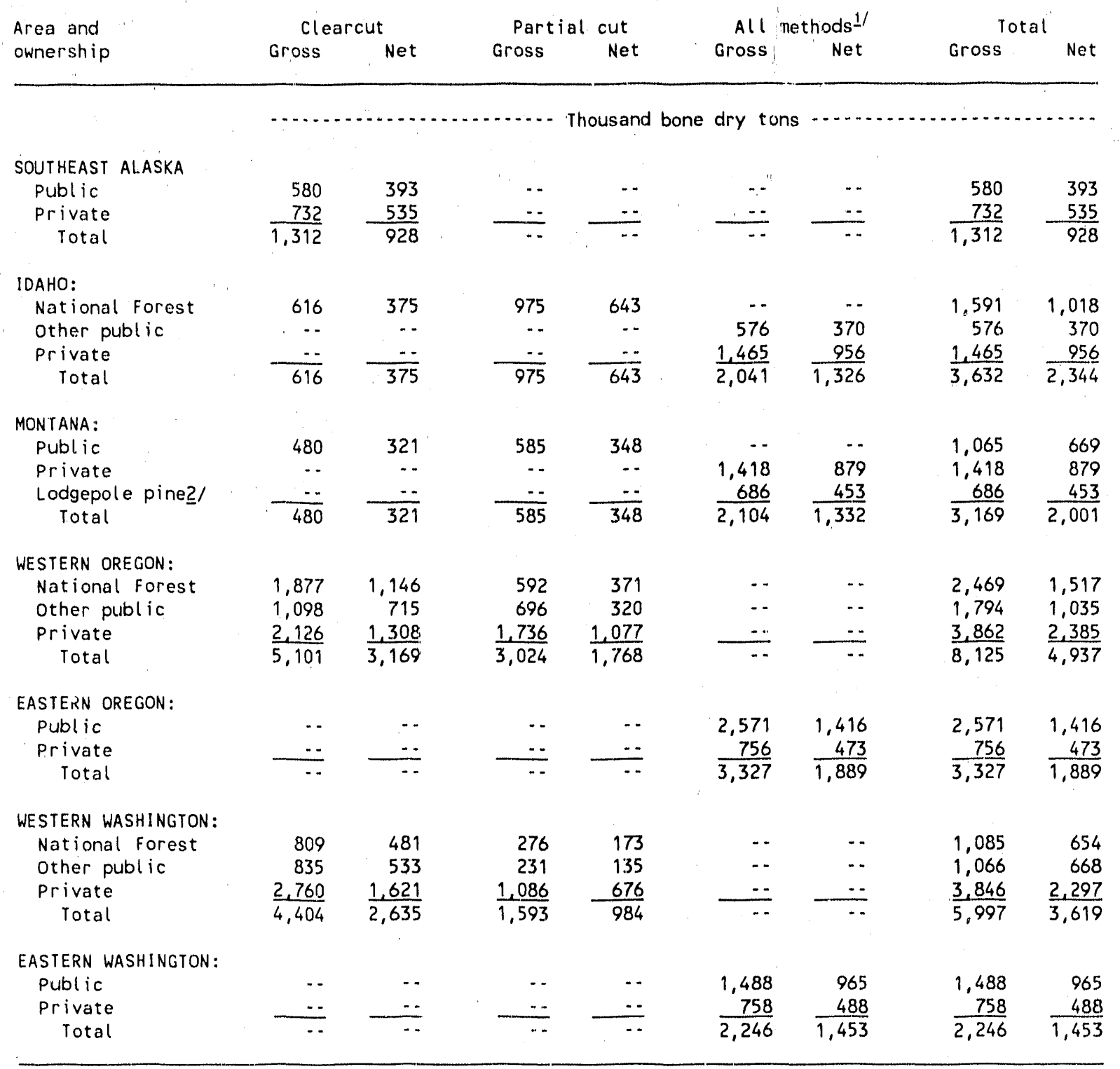

NOTE: - means no data are availble.

1/Samples were selected from all harvest methods; most samples were from partial cut areas.

2/Data for pure lodgepole pine harvest areas; samples were selected from all harvest methods and ownership classes. 


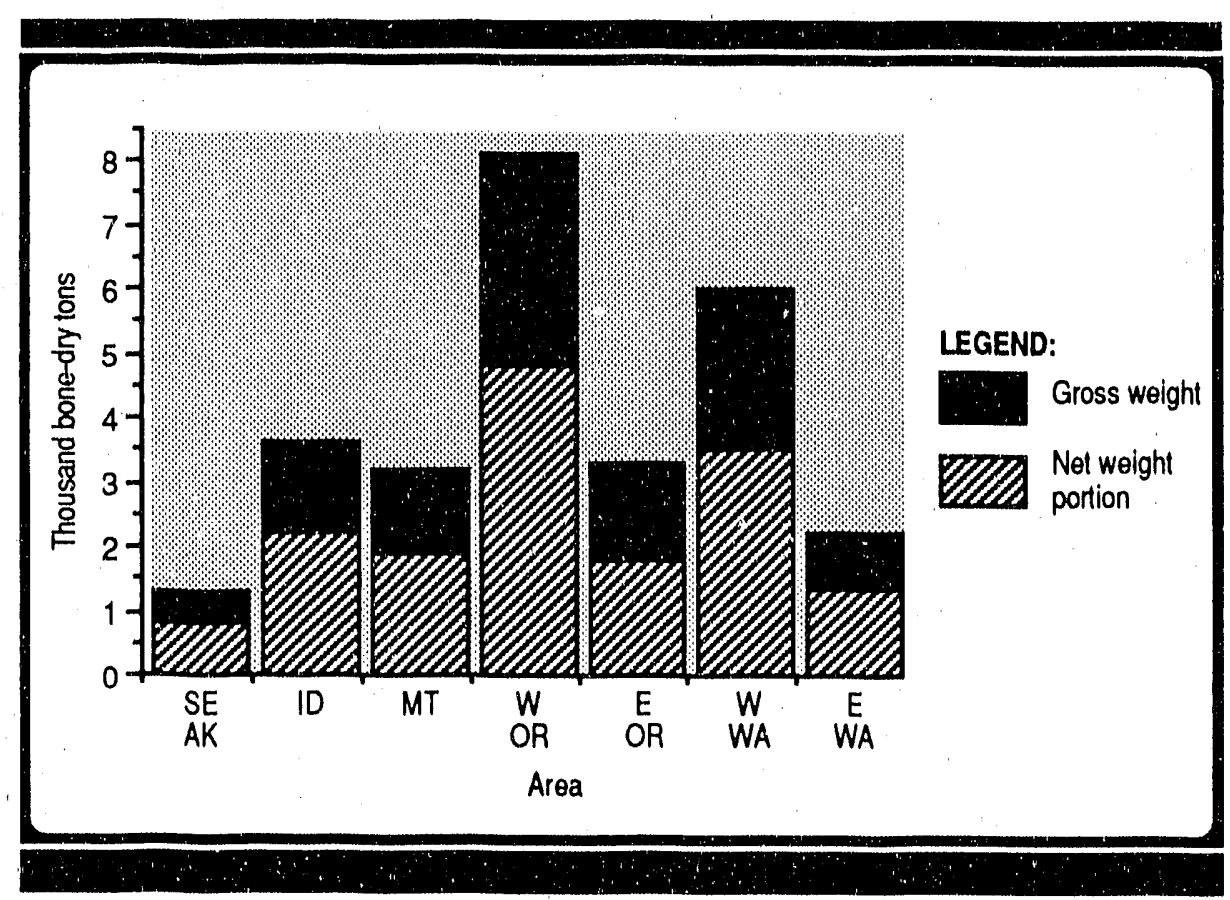

Figure 10: Gross and net weight of logging residue by area

Size, recoverable volume, location, and policies of land owners are examples of such factors. Some information needed to make feasibility assessments is provided in tables in the appendix of this report. Data given in tables 21-23 in the appendix can be used to determine the allocation of these weights by diameter and length classes, whether the material was live or dead $o_{i}$ cull at the time of harvest, and provides information on the number of pieces per acre. Also included in the appendix are factors (tables 18-20) that can be used to estimate gross and ret volumes of logging residue by owner class. These factors were the basis for the weight estimates shown in table 11. As table 11 shows about 7.4 million dry tons of residue comes from clearcut harvesting. This is 43 percent of the 17.2 million ton total. Some clearcutting does occur in the areas 
where residue is shown under the "all methods". Thus, the total weight of residue from clearcutting is a little higher that indicated above. Also notable is the distribution of residue by geographic area. Almost one-half, 8.6 million dry tons, of the total amount of residue exists in western Oregon and western Washington. The total weight in the other areas reflects either lower total harvest volumes, or lower per acre havest volumes. These figures do not include residue less than 3.0 inches in diameter, essentially the biomass in tree crowns. Region-wide estimates for this smaller material are not available, but the total weight is considerable. In terms of energy potential the opportunities are much less, since smaller size pieces tend to be much more costly to recover. Additionally, this source of residue is usually viewed as an important source of nutrients for future trees. The relative amount needed for this purpose is not well defined.

It should be noted that the logging residue weights provided in this report are not additive to the total weight of the biomass inventory (table 4). The inventory figure includes the biomass of all trees, above a 1.0 foot stump (excluding foliage). The logging residue figure includes parts of trees that remain on site following a logging operation. As such, residue biomass has been included in the inventory estimate. The term logging residue only defines the disposition of some biomass at the time of harvest.

Energy Potential

Energy potential as expressed here is defined as the maximum amount of energy that would be available if the stated source was fully converted at the highest level of efficiency. This of course is not feasible nor necessarily desirable in the real world. The value of figures reported here is for identification of those areas or sources with the greatest potential for energy production. Table 12 shows the energy potential by source of biomass for each geographic area. The total amount of energy represented by these sources, nearly 19 quads, is equivalent to 25 percent of current US consumption. 


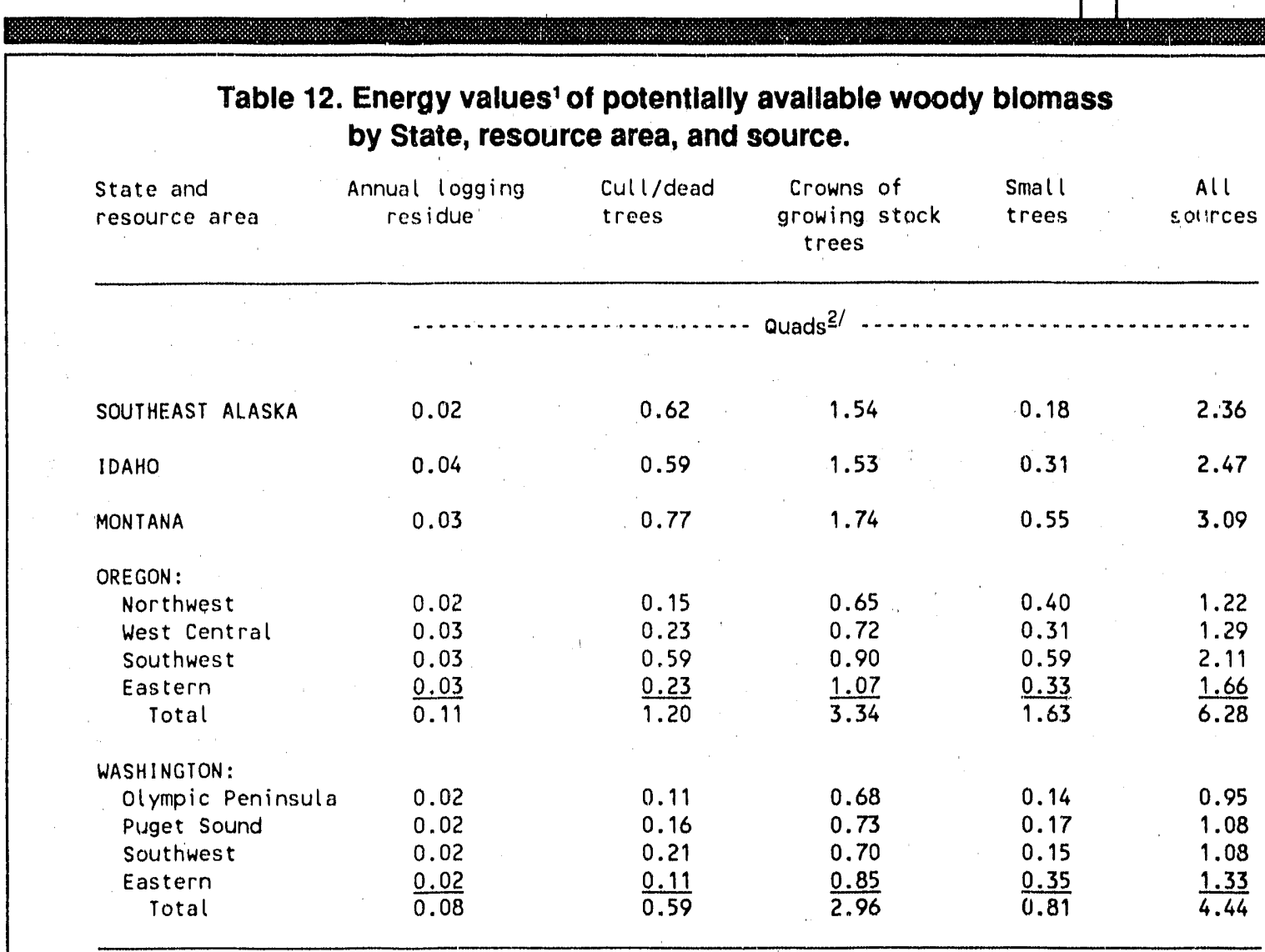

1/Derived by converting bone dry tons to maximum heating value using an average of 17,000,000 Btu's per ton.

2/A quad equals $1 \times 10^{15}$ Btu's.

The logging residue figure is based on estimated annual quantities of residue created as a result of current levels of timber harvesting. The other biomass energy sources are based on standing inventory data, and as such would be available for conversion to energy over a considerable time period. No attempt has been made to estimate the time period over which this material might enter the energy market. As will be discussed below there are other sources of woody

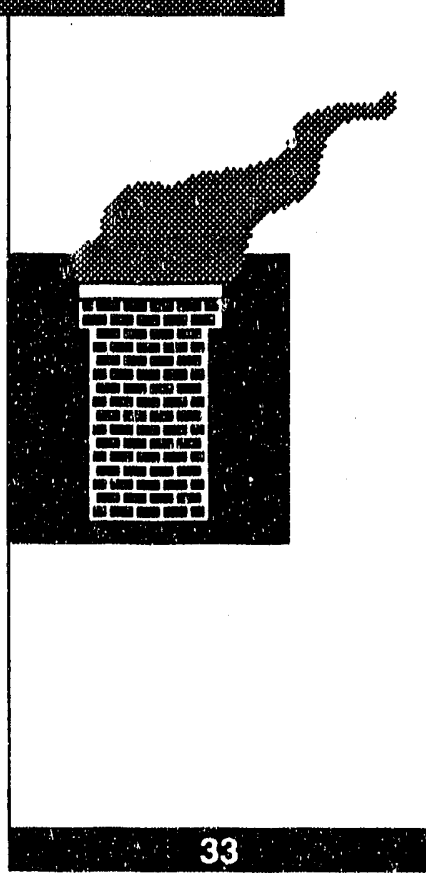


biomass that might provide additional opportunities for energy conversion. The relative contribution of each source of woody biomass is shown in figures 11 and 12. Since logging resioue is an annual estimate it is pioportionally less than the other sources. Realistically speaking, the other sources of biomass are the resource from which logging residue is created during harvest. Thus, in the current energy market, logging residue represents the main portion of the other sources that might be considered available on an annual basis. Even this arnuw it is significant if converted into energy. The total value for logging residue is about 0.3 quad, almost 10 times the energy output of the Trojan nuclear plant operating at 80 percent of capacity.

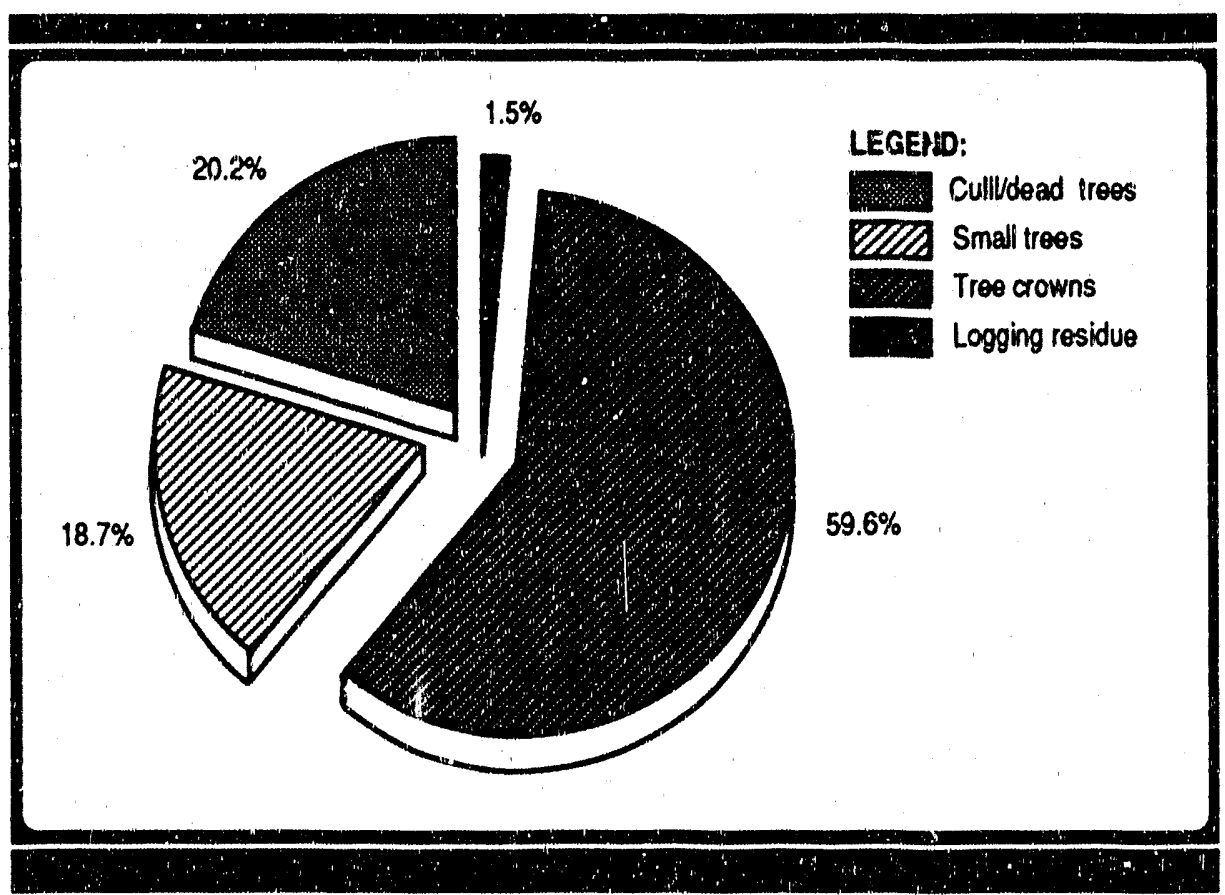

Figure 11: Proportion of total energy potential for each source 

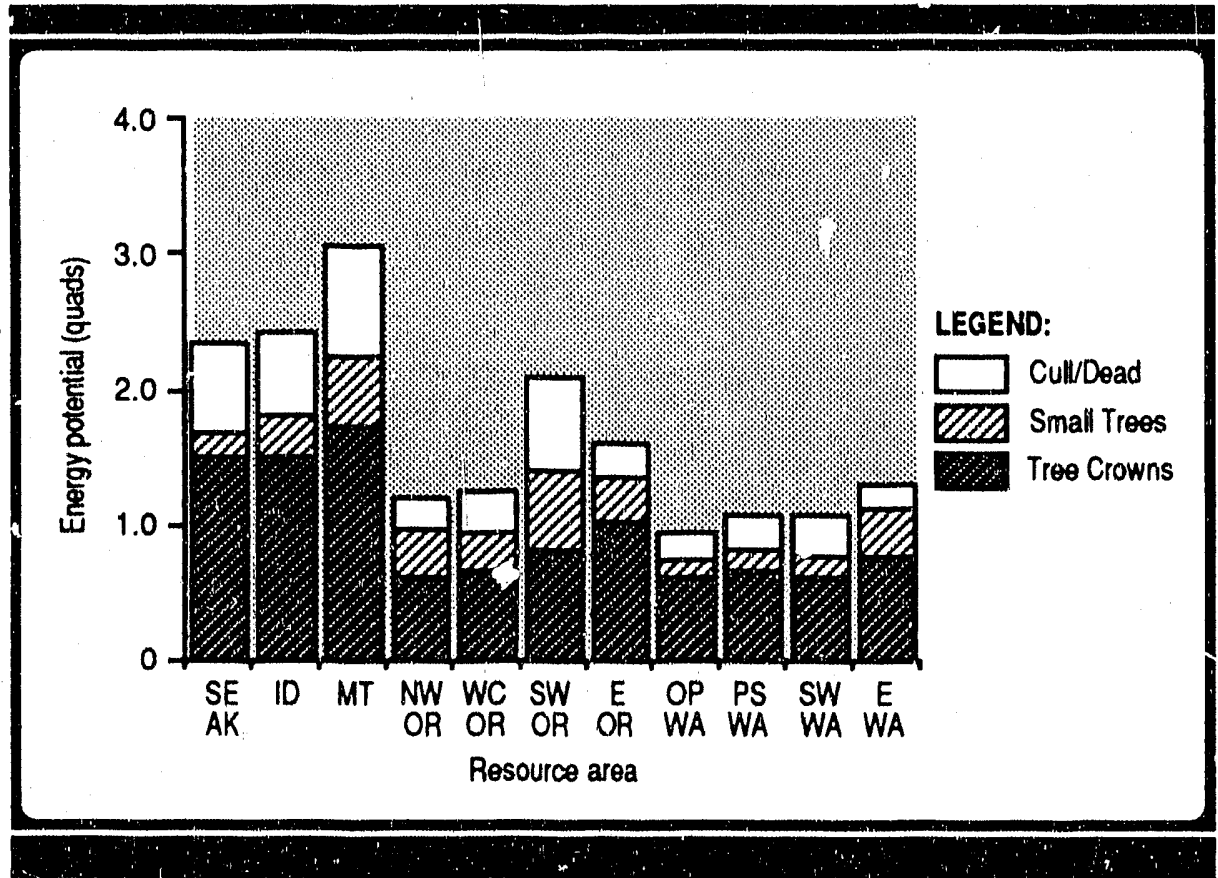

Figure 12: Distribution of total biomass inventory by source by resource Area

Each source of biomass has unique characteristics and opportunities for energy production. These unique aspects are briefly described below.

Logging residue - As noted earlier, the figure for logging residue does not include materials less than 3.0 inches in diameter. This would be primarily tree crowns. Thus, the energy value noted above is only part of the absolute total quantity that exists. It is questionable whether this smaller material would be converted to energy in todays technological and energy environment. This material is also considered to be valuable for maintaining site productivity and habitat for many animal species, atthough the amount and distribution for these purposes is not well defined. With these existing constraints it would seem unreasonable to expect much of a contribution from this small diameter material. 
Changing harvest technology, coupled with growing demand for all wood producis, may result in a different utilization rate for these smaller tree components in the future. As we look into the future we will be paying less attention to what we now call logging residue and more to total biomass management. Eventually the term logging residue will become obsolete.

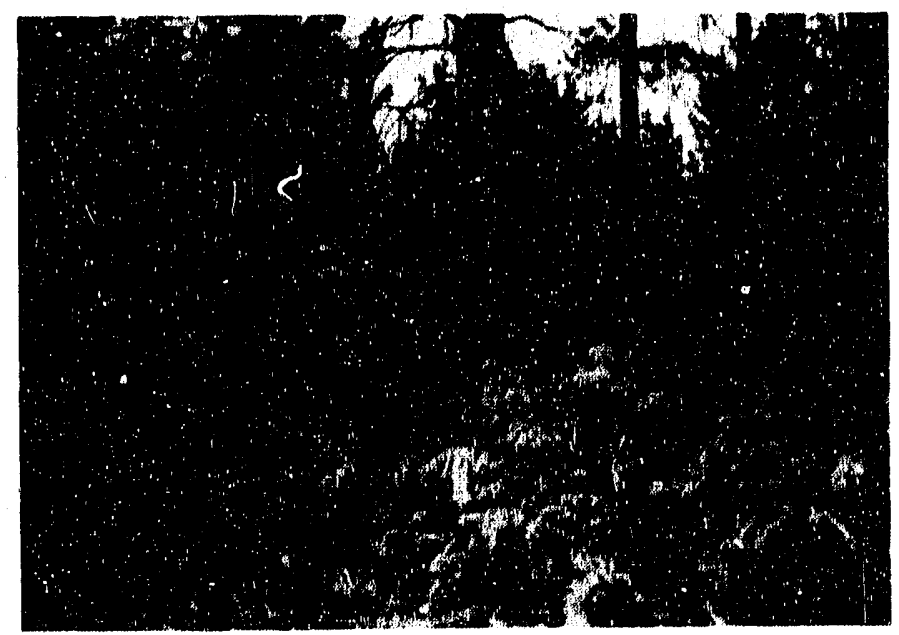

Figure 13: Small size residue (less than 3.0 inches) such as this may be available for energy.

The amount of logging residue that might enter the energy market under current circumstances is a function of cost of recovery, transportation distance, and energy values. All of these are in relation to location of the conversion facility. What may be feasible in western Washington, may not be economically possible in the more sparsely timbered areas in Idaho and Montana. Thus, site specific analyses are needed to determine the amount of residue that may be converted into energy. A recent report to the U.S. Department of Energy (Envirosphere 1986 a,b) provides supply curves for logging residue for the five state area encompassing Region $X$ of DOE. This information may be useful in making the economic assessments needed to determine the feasibility of converting residue to energy for a specific location in the 5-State area. 
Cull/Dead trees-Energy potential from this source is fairly significant, nearly 4 quads. A key question for these sources, however, is availability. For the most part cull and dead trees are scattered throughout the forests of the 5-State area, an exception being concentrations of dead trees caused by incidents such as insect epidemics. Trees in this classification tend to be associated with older stands, with areas like southeast Alaska and southwest Oregon, where large acreages of older stands exist, having higher concentrations of biomass in cull and dead trees. Absolute quantities, and therefore opportunities for recovery of this material for energy, are higher for these areas than for areas where younger forests predominate.

Figure 14: Cull trees, which contain logs like this, and dead trees are a significant but widely scattered resource.

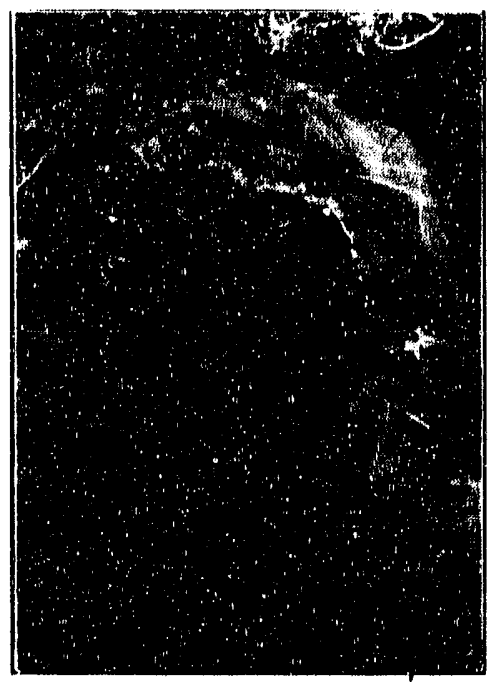

The scattered nature of cull and dead trees inhibits their recovery for energy because of higher harvesting costs. As a result, biomass from these sources is generally associated with normal harvesting operations, or salvage sales. Even the salvage sales tend to produce a high proportion of product recovery for other uses. In areas with flatter terrain, characteristic of the ponderosa pine type east of the Cascades, there are greater opportunities for recovery of cull and dead trees. This is due largely to lower harvesting costs and the partial cut practices that are common to these areas. For most areas it is likely that good energy markets might spur recovery of additional amounts of cull and dead biomass. 
Tree crowns-Crowns of live trees comprises the single largest source of biomass in the 5-State area, over 11 quads. As defined earlier this does not include foliage, which would add considerably to this total. Obviously crowns should not be considered as a source for energy conversion independent of the entire tree. Nor should the total amount of potential energy be considered as being available for energy production. The forest resource will be managed and harvested in conjunction with a complex set of societal and owners objectives. As trees are deemed ready for harvest the crown portion then comes into the energy equation. As is the case for logging residues, some quantity of crown material may be left on site to enhance or protect other environmental considerations or for future site productivity. How much of thismaterial needs to be left on site is under investigation and will probably vary considerably from one area to another.

The opportunity to utilize crown biomass for energy, or other products for that matter, is much greater for younger stands. Average diameters of these stands is considerably less than for the old growth stands that have constituted most of the harvest for this decade. Smaller trees are more likely to be harvested by mechanical means, or if don $i$ by hand are less apt to breakup during the felling process. Harvesting whole trees or longer sections with crowns intact will provide economic incentives for greater utilization of crown materials. In general the amount of crown biomass entering the energy market will be closely tied to harvest levels and criteria that determine the proportion that must remain on site. The opportunity to extend harvest to trees of marginal value will be greater if a larger portion of the tree can be marketed. Thus, expanding energy markets might actually result in greater amounts of these materials being available fol utilization. A key to greater utilization of crown biomass will be efficient handling and processing technology. Lower valued products usually require a higher degree of efficiency to ensure economic feasibility of recovery. New technologies may help bridge this gap. 
Small trees-Trees less than 5.0 inches in diameter account for a significant energy opportunity in total, about 3.5 quads, but are extremely variable in terms of real opportunity. These trees, along with seedlings less than 1.0 inch in diameter, represent our future forests. As such they would not be considered as a current source of raw material for energy or any otherproduct. For the most part small trees occur as components in stands with larger trees, or as the single component, such as following clearcutting, or fires and other natural catastrophes. In the first case they may be an integral part of the stand structure, representing one of several age classes. In the latter case they are from natural or planted origins and of varying stocking densities. In either case overstocking of small trees may present an opportunity for energy conversion.

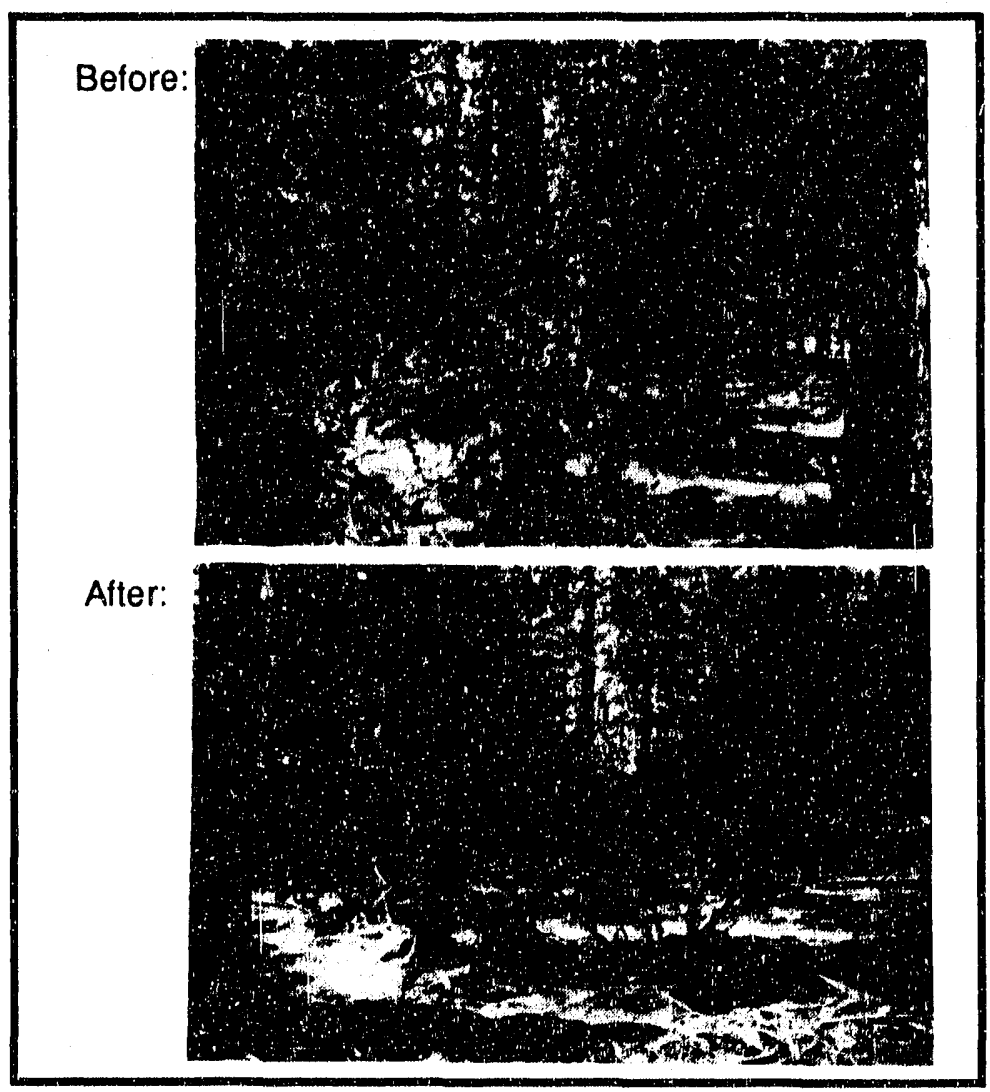

Figure 15: Recovery of biomass from thinning small trees may be an important source of wood for energy in the future. 
Reducing the density of overstocked stands is usually accomplished by thinning operations. In many operations, called pre-commercial thinnings, unwanted trees are cut and left to decay, providing greater growing space for remaining desirable trees. These procedures are expensive and usually do not result in removal of products until the trees are larger; the operations are then called commercial thinnings. The smaller trees have rarely had much product value, off site that is. This has contributed to a lower than desirable level of thinning operations for most land owners. A viable market for small trees might change the situlation considerably. First, additional biomass might be recovered from current or planned operations. Secondly, the ability to generate some income from these operations might create opportunities for additional thinnings that would othenwise be passed over. While thinnings do take place, there are thousands of acres of forests in the 5-State area that could benefit from thinning, but are being delayed because of high treatment costs. It is these stands, along with some having slightly larger trees, that represent a significant opportunity tu recover energy wood. The extent and feasibility of these opportunities are unique to each location. Availability to energy markets may be a key to more intensive forest management in the future.

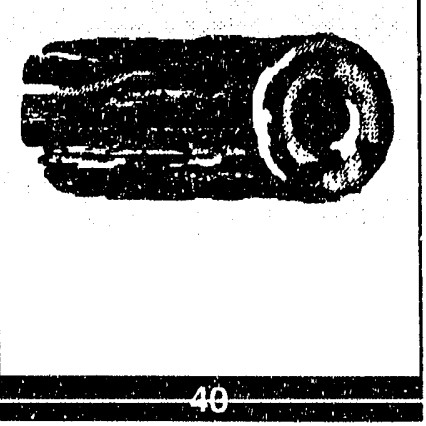


In addition to woody biomass currently being converted to energy, primarily in the forest industries and for residential heating, the forests of the Pacific Northwest and Alaska represent a significant opportunity to help meet future energy needs. The extent to which these forests contribute is a function of a complex set of criteria, and varies considerably from one geographic area to another. Expanding the use of woody biomass for energy holds promise not only for meeting growing demands, but may provide an economic incentive for intensifying management of the region's forests. Obviously only a small portion of the nearly 19 quads of energy from the sources in this report will be physically available in any given year. Even less may find its way to markets because of critical economic factors. But, the amount that does reach conversion facilities can make a significant and lasting contribution to the region's energy requirements. Unlike other sources of energy, woody biomass is a renewable resource.

There are other sources of forest biomass not addressed by this report. The largest such source is biomass occurring on what are frequently referred to as non-commercial forests. Juniper stands in eastern Oregon and Washington are examples of this type of forest. Data in table 1 showed a total of just over 25 million acres of "otherforest land" in the 5-State ar.9a. Much of this land is covered with trees that are not generally considered to bf of commercial value. Eastern Oregon alone has over 3.6 million acres of othir forest land, most of which is occupied by non-commercial species (Farrenkopf 1982). The very definition of these stands indicates that few products are removed from trees growing on these sites. In some case s products such as posts, poles, and firewood are taken from these forests. Large scale removal of biomass from these forests may not be reasonable for a number of reasons. They do, however, represent a potentially large source of biomass, particularly for products that do not require high quality wood-such as energy.

Reliability of data for most of the sources of biomass presented in this report is difficult to assess. Each of the Forest Service reports from which inventory 
volumes were derived, gives information on sampling errors for land area ard volume. These sampling errors, however, do not apply to the total biomass estimates in this report, which were constructed by applying factors to the basic inventory estimates. Thus, sampling errors for total tree biomass estimates by resource area were not determined. The main stem of a tree accounts for the largest proportion of total tree biomass, and the sampling errors associated with this portion are relatively low as indicated in the Forest Service repurts. Therefore, the combined error associated with total tree biomass in almost all cases will be lower than that for the non-stem portion of a tree. For example, $c$ standard error of 5 percent for the main stem and 25 percent for the other biomass components, could result in a combined error as low as 10 percent for total tree biomass, because the biomass of the main stem accounts for such a large proportion of the total biomass of the tree. The data presented here provides information on the relative size and distribution of biomass for the resources areas. Site specific needs should be met by deriving estimates from the local data base. Standard errors for logging residue estimates are available in the referenced reports. Since total residue estimates rely on actual harvest figures, errors associated with the totals should be the same as those associated with the estimators themselves.

Whether augmenting regional supplies or facilitating forest management, the use of woody biomass for energy has the potential to impact both people and forests of the region. Energy markets in the 5-State area are currently not conducive to rapid growth in the use of woody biomass. Likewise, there are many gaps in harvesting and processing technologies needed to support this growth. Finally, we do not fully understand the role of woody biomass in the enhancement and protection of the forest environment. Time, however, will see changes in all three elements: markets, technology, management. It is anticipated that woody biomass will play a larger rolf in future energy production. The extent and rapidity with which this may occur is unknown. Another unknown, and a potentially major consideration, is the effect of international energy demands and politics on utilization of the region's forest biomass. While not widely discussed, 
the potential exists for forests within the 5-State area to becorne significant sources of wood for the many nations in the world that are facing serious shortages of fuel for cooking and heating. It would not be unreasonable to expect these countries to look toward the U.S. for assistance with this critical issue. Following the example of other commodities, we could easily see a flow of woody biomass to some of these countries within a matter of years.

How much and when are the main questions concerning the use of woody biomass for energy. Possibly where should be added to that list. The resource available to support this use is large and spread throughout the 5.State area of the Pacific Northwest and Alaska. A great deal of research, development, and innovation will occur as we move toward the year 2000 . All three will be necessary to ensure efficient and effective management of this important resource. 


\section{References}

(1) Adamovich, L.L. 1975. Engineering characteristics of Canadian trees, centre of gravity and green weight of components of three conifers in interior British Columbia on poor growing sites. Information Rep. FMR-X-82. Vancouver, British Columbia, Canada: University of British Columbia, Forest Management Institute. $65 \mathrm{p}$.

(2) Bassett, Patricla Ml.; Oswald, Danlel D. 1981. Timber statistics for southwest Washington. Rescur. Bull. PNW-RB-91. Portland, OR:U.S. Department of Agriculture, Fores! Se $^{\prime}$ vice, Pacific Northwest Forest and Range Experiment. Station. $24 \mathrm{p}$.

(3) Bassett, Patricla M.; Oswald, Danlel D. 1981. Timber statistics for the Olympic Peninsula, Washington. Resour. Bull. PNW-RB-93. Portland, OR:U.S. Department of Agriculture, Forest Service, Pacific Northwest Forest and Range Experiment Station. $31 \mathrm{p}$.

(4) Bassett, Patricia M.; Oswald, Daniel D. 1982. Timber statistics for the Puget Sound area, Washington. Resour. Bull. PNW-RB-96. Portland, OR: U.S. Department of Agriculture, Forest Service, Pacific Northwest Forest and Range Experiment Station. $31 \mathrm{p}$.

(5) Bassett, Patricia M.; Oswald, Daniel D. 1983. Timber statistics for eastern Washington. Resour. Bull. PNW-RB-104. Portland, OR: U.S. Department of Agriculture, Forest Service, Pacific Northwest Forest and Range Experiment Station. 32 p.

(6) Benson, Robert E.; Green, Alan W.; Van Hooser, Dwane D.1987. Idaho's Forest Resource. Resour. Bull. INT-RB-39. Ogden, UT: U.S. Department of Agriculture, Forest Service, Intermountain Research Station. 114 p.

(7) Brackett, Michael.1973. Notes on tarif tree volume computation. Resource Management Report \#24. Olympia, WA: State of Washington, Department of Natural Resources. $26 \mathrm{p}$.

(8) Brown, James K. 1978. Weight and density of crowns of Rocky Mountain conifers. Res. Pap. INT-RP-197. Ogden, UT: U.S. Department of Agriculture, Forest Service, Intermountain Forest and Range Experiment Station. $56 \mathrm{p}$.

(9) Envirosphere C'ompany, 1986a. Regional logging resic se supply curve project, Volume 1 - Final report. Report to U.S. Department of Energy, Pacific Northwest and Alaska Regional Bioenergy Program (Bonnnville Power Administration). Bellevue, WA: Envirosphere Company. [Not paged]. 
(10) Envirosphere Company, 1986b. Regional logging residue supply curve project, Volume 2 - Appendices. Report to U.S. Department of Energy, Pacific ivuriliwest and Alaska Regional Bioenergy Program (Bonnnville Power Administration). Bellevue, WA: Envirosphere Company. [Not paged].

(11) Farrenkopf, Thomas O. 1982. Forest statistics for eastern Oregon, 1977. Resour. Bull. PNW-RB-94. Portland, OR:U.S. Department of Agriculture, Forest Service, Pacific Northwest Forest and Range Experiment Station. 28 p.

(12) Forest Products Laboratory. 1987. Wood handbook: wood as an engineering material. Agric. Handb. 72. Washington, DC: U.S. Department of Agriculture; rev. $1987.466 \mathrm{p}$.

(13) Gedney, Donald R. 1982. The timber resources of western Cregonhighlights and statistics. Resour. Bull. PNW-RB-97. Portland, OR: U.S. Department of Agriculture, Forest Service, Pacific Northwest Forest and Range Experiment Station. $84 \mathrm{p}$.

(14) Gholz, H.L.; Grier, C.C.; Campbell, A.G.; Brown, A.T. 1979. Equations for estimating biomass and leaf area of plants in the Pacific Northwest. Res. Pap. 41. Corvallis, OR: Oregon State University, School of Forestry, Forest Research Laboratory. $39 \mathrm{p}$.

(15) Green, Alan W.; O'Brien, Renee A.; Schaefer, James C. 1985. Montana's Forests. Resour. Bull. INT-RB-38. Ogden, UT: U.S. Department of Agriculture, Forest Service, Intermountain Research Station. 70p.

(16) Howard, James O. 1981a. Ratios for estimating logging residue in the Pacific Northwest. Res. Pap. PNW-RP-288. Portland, OR: U.S. Department of Agriculture, Forest Service, Pacific Northwest Forest and Range Experiment Station. $26 \mathrm{p}$.

(17) Howard, James O. 1981b. Logging residue in the Pacific Northwest: characteristics affecting utilization. Res. Pap. PNW-RP-289. Portland, OR:U.S. Department of Agriculture, Forest Service, Pacific Northwest Forest and Range Experiment Station. $41 \mathrm{p}$.

(18) Howard, James O.; Fledler, Carl E. 1984. Estimators and characteristics of logging residue in Montana. Res. Pap. PNW-RP-321. Portland, OR: U.S. Department of Agriculture, Forest Service, Pacific Northwest Forest and Range Experiment Station. $29 \mathrm{p}$.

(19) Howard, James O.; Setzer, Theodore S. 1989. Logging residue in southeast Alaska. Res. Pap. PNW-RP-405. Portland, OR: U.S. Department of Agriculture, Forest Service, Pacific Northwest research Station. $36 \mathrm{p}$. 
(20) Johnstone, W. D. 1970. Component dry weights of 100-years-old lodgepole pine trees. Infor. Rep. A-X-31. Calgary, Alberta, Canada: Canadian Forestry Service, Department of Fisheries and Forestry. $14 \mathrm{p}$.

(21) Keays, J. L. 1971. Complete-tree utilization, an analysis of the literature, Part I: unmerchantable top of bole. Infor. Rep. VP-X-69. Vancouver, British Columbia, Canada: Canadian Forestry Service, Department of Fisheries and Forestry. $98 \mathrm{p}$.

(22) Keays, J. L. 1971. Complete-tree utilization, an analysis of the literature, Pant III: branches. Information Report VP-X-71. Vancouver, British Columbia, Canada: Canadian Forestry Service, Department of Fisheries and Forestry. $98 \mathrm{p}$.

(23) LaBau, Vernon J.; Van Hees, Willem W.S. 1983. Timber resource statistics for the Juneau inventory unit, Alaska, 1970. Resour. Bull. PNW-RB98. Portland, OR: U.S. Department of Agriculture, Forest Service, Pacific Northwest Forest and Range Experiment Station. $30 \mathrm{p}$.

(24) LaBau, Vernon J.; Hutchison, O. Kel: h. 1976. Timber supply and use in the Haines-Skaway area, Alaska. Resour. Bull. PNW-RB-67. Portland, OR: U.S. Department of Agriculture, Forest Service, Pacific Northwest Forest and Range Experiment Station. 44p.

(25) Maxwell, Wayne G.; Ward, Franklin R. 1976. Photo series for quantifying forest residue in the: coastal Douglas-fir - hemlock type, coastal Douglas-fir hardwood type. Gen. Tech. Rep. PNW-GTR-51. Portland, OR: U.S. Department of Agriculture, Forest Service, Pacific Northwest Forest and Range Experiment Station. $103 p$.

(26) PIIIsbury, Norman H.; Stephens, Jeffery A. 1978. Hardwood volume and weight tables for California's central coast. For the Central Coast Resource Conservation and Development Project. San Luis Obispo, CA: California Polytechnic State University, Natural Resources Management Department. 54 p.

(27) Shaw, D.L. 1977. Biomass equations for Douglas-fir, western hemlock, red cedar, and red alder in Washington and Oregon. Tech. Rep. 044-3001/77/ 22. Centralia, WA: Weyerhaeuser Corporation, Western Forestry Research Center. $19 p$.

(28) Snell, J.A. Kendall; Max, Timothy A. 1982. Bark-to-wood ratios for logging residue in Oregon, Washington, and Idaho. Admin. Rep. Portland, OR: U.S. Department of Agriculture, Forest Service, Pacific Northwest Forest and Range Experiment Station. $9 \mathrm{p}$. 
(29) Snell, J.A. Kendall; Little, Susan N. 1983. Predicting crown weight and bole of five western hardwoods. Gen. Tech. Rep. PNW-GTR-151. Portland, OR: U.S. Department of Agriculture, Forest Service, Pacific Northwest Forest and Range Experiment Station. $37 \mathrm{p}$.

(30) Stanek, W.; State, D. 1978. Equations, predicting primary productivity (biomass) of trees, shrubs and lesser vegetation based on current literature. Infor. Rep. BC-X-183. Victoria, British, Canada: Environment Canada, Canadian Forestry Service, Pacific Forest Research Centre. $58 \mathrm{p}$.

(31) U.S. Department of Agrlculture, Forest Service. 1981a. Tree biomassa state-of- the-art compilation. Gen. Tech. Rep. WO-GTR-33. Washington, DC: U.S. Department of Agriculture, Forest Service. $34 p$.

(32) U.S. Department of Agriculture, Forest Service. 1981b. An assessment of the forest and range land situation in the United States. For. Res. Rep. No. 22. Washington, DC: U.S. Department of Agriculture, Forest Service. 352 p.

(33) Van Hees, Willem W.S. 1984. Timber resource statistics for the Ketchikan inventory unit, Alaska, 1974. Resour. Bull. PNW-RB-117. Portland, OR: U.S. Department of Agriculture, Forest Service, Pacific Northwest Forest and Range Experiment Station. $33 \mathrm{p}$.

(34) Van Hees, Willem W.S.; LaBau, Vernon J. 1983. Timber resource statistics for the Sitka inventory unit, Alaska, 1971. Resour. Bull. PNW-RB-101. Portland, OR: U.S. Department of Agriculture, Forest Service, Pacific Northwest Forest and Range Experiment Station. $35 \mathrm{p}$.

(35) Van Hees, Willem W.S.; LaBau, Vernon J. 1983. Timber resource statistics for the Prince of Wales inventory unit, Alaska, 1973. Resour. Bull. PNW-RB-103. Portland, OR: U.S. Department of Agriculture, Forest Service, Pacific Northwest Forest and Range Experiment Station. $30 \mathrm{p}$.

(36) Van Hees, Willem W.S.; LaBau, Vernon J. 1983. Timber resource statistics for the Petersburg/Wrangell inventory unit, Alaska, 1972. Resour. Bull. PNW-RB-102. Portland, OR: U.S. Department of Agriculture, Forest Service, Pacific Northwesi Forest and Range Experiment Station. $36 \mathrm{p}$.

(37) Van Hees, Willem W.S.; LaBau, Vernon J. 1984. Timber resource statistics for the Yakutat inventory unit, Alaska, 1975. Resour. Bull. PNW-RB 105. Portland, OR: U.S. Department of Agriculture, Forest Service, Pacific Northwest Forest and Range Experiment Station. $31 \mathrm{p}$. 
(38) Waldrop, Thomas A.; Brooks, Robert T. Jr. 1984. Woody biomass analysis for 13 southeastern states. Tech Note B52. Knoxville, TN: Tenn ssee Valley Authority, Division of Land and Economic Resources, Office of Natural Resources and Economic Development. 149 p.

(39) Yarle, John; Mead, Delbert R. 1982. Aboveground tree biomass on productive forest land in Alaska. Res. Pap. PNW-RP-298. Portland, OR: U.S. Department of Agriculture, Forest Service, Pacific Northwest Forest and Range Experiment Station. $16 \mathrm{p}$.

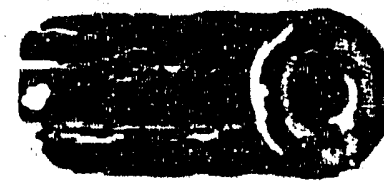


Basal area - The area in square feet (square meters) of the cross section at breast height of a single tree or of alltrees in a stand, usually expressed as square feet (square meters) of basal area per acre (hectare).

Class of timber - A classification of trees as gro' wing stock, cull, and salvable dead. Growing stock trees are subdivided into seedling, sapling, poletimber, and sawtimber trees.

Cull trees - Live trees of noncommercial species, or live trees of commercia! species that are more than 75-percent defective or with defect caused primarily by poor form or roughness, and are unlikely to become growing stock.

Diameter class - A classitication of trees based on diameter outside bark measured at breast height, $4-1 / 2$ feet $(1.37 \mathrm{~m})$ above the ground. D.B.H. is the common abbreviation for "diameter at breast height".

Forest industry lands - Lands owned by companies or individuals owning or operating wood-using plants.

Forest land - Land at least 10 percent ( 16.7 percent in southeast Alaska) stocked with live trees or land formerly having such tree cover and not currently developed for nonforest use.

Forest types - Stands with 50 percent or more stocking in live conifer trees are classified as softwood types. Stands with a majority of stocking in live hardwood trees are classified as hardwood types. Within these two groups, the individual forest type is determined by plurality of stocking by species of live sottwood or hardwood trees.

Growing stock trees - All live trees with the exception of cull trees.

Growing stock volume - Net volume in cubic feet of live sawtimber and poletimber growing stock trees from slump to a minimum 4-inch $(10 \mathrm{~cm}$ ) top (of central stem) outside bark. Net volume equals gross volume less deduction for rot and missing bole sections.

Hardwoods - Trees that are angiosperms, usually broad-leaved and deciduous.

Land area - Area as reported as land by the Bureau of Census. Total land area includes dry land and land temporarily or partially covered by water such as marshes, swamps, and river flood plains; streams, sioinhs, and canals less than $1 / 8$-mile $(200 \mathrm{~m})$ wide; and lakes, recervoirs, and ponds less than 40 acres (16 ha) in area.

\section{Glossary}

\section{A. Forest Inventory Terrns}


Mean annual Increment - A measure of the productivity of forest land in terms of the average increase in cubic-foot volume per acre per year. For a given species and site index the average is based on the number of years needed for the mean annual increment to culminate in fully stocked stands.

Mortality - Volume of sound wood in trees dying from natural causes during a specified period, such as between inventories.

National Forest lands - Federal lands which have been designated by Executive order or statute as National Forest or purchase units and other lands under the administration of the Forest Service, including experimental areas and Bankhead-Jones Title III lands.

Net annual growth - The net increase in volume of trees during a specified year. Components of net annual growth of trees: (a) the increment in net volume of trees alive at the beginning of the specified year and surviving to the year's end, plus (b) the net volume of trees reaching sawtimber or poletimber size during the year, minus (c) the net volume of trees that died during the year, minus (d) the net loss to tree decay during the year.

Noncommerclal species - A tree species not suitable for industrial wood products.

Nonforest land - I.and that has never supported forests or was formerly forested and is currently developed for nonforest uses. Included are lands used for agriculturai rrops, Christmas tree farms, improved pasture, residential areas, city parks, improved roads, operating railroads and their right-of-way clearings, powerline and pipeline clearings, streams over 30 feet $(10 \mathrm{~m})$ wide, and 1- to 40-acre (0.4- to 16- ha) areas of water classified by the Bureau of Census as land. If intermingled in forest areas, unimproved roads and other nonforest strips must be more than 120 feet $(35 \mathrm{~m})$ wide, and clearings or other areas must be 1 acre $(0.4 \mathrm{ha})$ or larger in size to qualify as nonforest land.

Nonstocked areas - Timberland less than 10 percent (16.7 percent in southeast Alaska) stocked with growing stock irees.

Other forest land - Forest land incapable of producing 20 cubic feet per acre per year of industrial wood because of adverse site conditions such as sterile soils, dry climate, poor drainage, high elevation, steepness, or rockiness; or public land withdrawn from timber utilization through statute, ordinance, or administrative order but which otherwise qualifies as timberland; or National Forest timberland temporarily withdrawn from timber utilization and .... Ser study for possible inclusion in the wilderness system. 
Other private lands - All privately owned lands except those classed as forest industry lands.

Other publlc lands - Lands administered by public agencies other than the Forest Service.

Poletimber stands - Stands of timberland with a mean diameter (weighted by basal area) from 5.0-9.0 inches (12.5-22.5 cm) if softwood and from 5.0-11.0 $(12.5-27.5 \mathrm{~cm})$ if hardwood.

Poletimber trees - Live trees of commercial species at least 5.0 inches (12.5 $\mathrm{cm}$ ) in d.b.h. but smaller than sawtimber size, and of good form and vigor.

Salvable dead trees - Standing or down trees of commercial species, at least 9.0 inches $(22.5 \mathrm{~cm})$ in d.b.h for softwoods and at least 11.0 inches $(27.5 \mathrm{~cm})$ in d.b.h. for hardwoods, containing 25 percent or more sound wood volume and at least one merchantable 12-foot $(3.8-\mathrm{m}) \log$ if softwood or one merchantable 8foot $(2.5-\mathrm{m}) \mathrm{log}$ if hardwood.

Sapling and seedling stands - Stands of timberland with a mean diameter (weighted by number of trees) less than 5.0 inches $(12.5 \mathrm{~cm})$.

Sapling and seedling trees - Live trees of commercial species less than 5 inches $(12.5 \mathrm{~cm})$ ind.b.h. with no disease, defects, or deformities likely to prevent their becoming poletimber trees.

Sautimber stands - Stands of timberland with a mean diameter (weighted by basal area) larger than 9.0 inches $(22.5 \mathrm{~cm})$ if softwood $(11.0$ inches [27.5 $\mathrm{cm}$ ] in southeast Alaska) and larger than 11.0 inches $(27.5 \mathrm{~cm})$ if hardwood.

Sawtimber trees - Live softwood trees of cornmercial species at least 9.0 inches $(22.5 \mathrm{~cm})$ in d.b.h. (11.0 inches $[27.5 \mathrm{~cm}$ ] in southeast Alaska) and hardwood trees of commercial species at least 11.0 inches $(27.5 \mathrm{~cm})$ in d.b.h. At least 25 percent of the board-fool volume in a sawtimber tree must be free from defect. Softwood trees must contain at least one 12-foot (3.8-m) saw log with a top diameter of not less than 6 inches $(15 \mathrm{~cm})$ inside bark; hardwood trees must contain at least one 8 -foot $(2.5-\mathrm{m})$ saw log with a top diarneter of not less than 8 inches $(20 \mathrm{~cm})$ inside bark.

Site class - A classification of the potential productivity of forest land, defined by capacity for cubic-foot annual growth per acre at culmination of mean annual growth in fully stocked natural stands. 
Softwoods - Coniferous trees, usually evergreen.

Stocking - A measure of the area occupied by trees of specified classes. FIA forest inventories consider three categories of stocking: all live trees, growing stock trees, and desirable trees. Stocking of all live trees is used to delineate forest land and forest types. Stocking of growing stock trees is used ir classifications of stand size and stand age. Stocking of desirable trees is used to delineate area condition classes.

Timber harvest - Volume of roundwood removed from forest land for products.

Timberland - Forest land capable of producing 20 cubic feet per acre (1.4 cubic meter per ha) per year of industrial wood, and not withdrawn from timber utilization.

Volume of growing stock - Volume of sound wood in the bole of live growing stock sawtimber and poletimber trees from stump to a minimum 4.0-inch (10$\mathrm{cm}$ ) top outside the bark or to the point where the central stem breaks into limbs.

\section{B. Logging Residue Terms}

Clearcut - A harvest operation in which all, or nearly all, trees in a stand are cut in one operation.

Cutover area - Synonymous with sample unit or sample area; the area encompassing a single harvest operation; a clearcut for example.

Harvest volume - Net scaled volume of timber removed, or estimated to be removed, from a cutover area during harvesting; expressed in thousand board feet (log scale, as reported by land owners) per acre (MBF/AC).

\section{Logging residue:}

General - All down and dead woody material existing on a cutover area after harvesting is completed; excluding standing trees or portions thereof.

Specific - All logging residue (as defined above) 3.01 inches $(7.5 \mathrm{~cm})$ and larger in diameter inside bark (d.i.b.) and 1.0 foot $(30.5 \mathrm{~cm})$ and longer in length; includes limbs, slabs, and splinters.

MBF - One thousand board feet of logs; a measure of the volume of timber harvested. 


\section{Owner class:}

Private - Lands owned by private individuals, forest industries, and Native and other corporations.

Public - Lands owned by the public or managed by a public agency.

Partial cut - A harvest method in which portions of a stand of timber are cut during a number of entries over time; precommercial thinnings are not included.

\section{Residue volume:}

Chippabllity - Condition of residue sound enough to be physically handled and capable of producing usable chips; includes residue exhibiting early stages of wet or dry rot.

Cull - Residue from trees that were cull (less than 25 percent sound) at the time of harvest.

Dead - Residue from trees or portions of trees that were dead before harvest; includes material on the ground at the time of harvest.

Gross - Volume of a piece of residue measured only by its external dimensions; includes rot, cracks, and missing parts.

Live - Residue from trees or portions of trees that were alive before they were cut or knocked down during harvest.

Net - The usable portion of a piece of residue; for this report, usability is based on physical chippability of the material and does not imply solid product potential.

Small-end-dlameter - measured inside bark at the smallest end of a piece of residue, to a 3.01 -inch $(7.5-\mathrm{cm})$ minimum.

Stratum - A category of timber harvest area defined for this study by land ownership.

Supply zone - A uniquely defined area containing timber or logging residue that is considered to be potentially available for a processing facility.

YUM (or PUM) - Terms used by the USDA Forest Service for large piles of residue yarded or bulldozed to a common location. If the residue has been piled with some degree of uniformity it is referred to as PUM (piled unmerchantable material); otherwise, the term YUM (yarded unmerchantable material) is used.

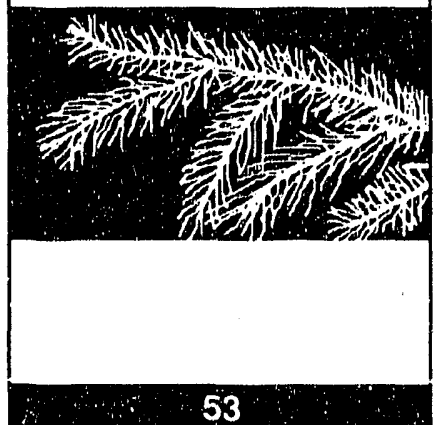




\section{Biomass Terms}

Blomass Inventory - The dry or green weight of wood and bark of trees, above a 1.0 foot $(30.5 \mathrm{~cm})$ stump, excluding foliage, that are at least 1.0 inch $(2.54 \mathrm{~cm})$ in diameter at d.b.h., and located on timberland.

Bole - All wood and bark of a tree above a 1.0 foot $(0.4 \mathrm{~m})$ stump and below the point where either the diameter of the central stem is less than 4.0 inches (10 $\mathrm{cm}$ ) or the central stem breaks into limbs.

Bone dry ton - One dry ton, 2000 pounds $(907.2 \mathrm{~kg})$, of wood or bark.

Branches - Weight of wood and bark of trees from point where main stem breaks into limbs to a minimum of $1 / 4$-inch $(0.6 \mathrm{~cm})$ in diameter; excluding foliage.

Crown - Synonymous with branches for this report.

Dry weight - Weight of wood or bark containing no water.

Green weight - Weight of wood or bark in its natural or growing condition; varies by season and location in tree; green weight is equal to dry weight times (1 + moisture content, oven dry basis).

Wood density - Weight of wood expressed in pounds per cubic foot, green or dry; affected by specific gravity and moisture content; where dry density is calculated by multiplying specific gravity of wood times the density of water (62.4 pounds per cubic foot).

Quad - Quadrillion (1×10 15) Btu's.

Top - Portion of the main stem or forks of a tree above 4.0 inches $(10 \mathrm{~cm})$ to the tip of the main stem or fork. 


\section{Appendix}

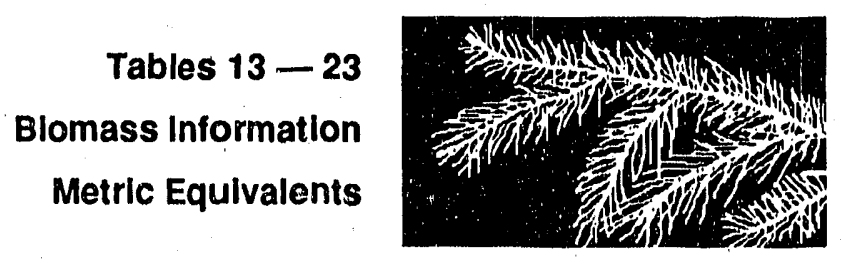

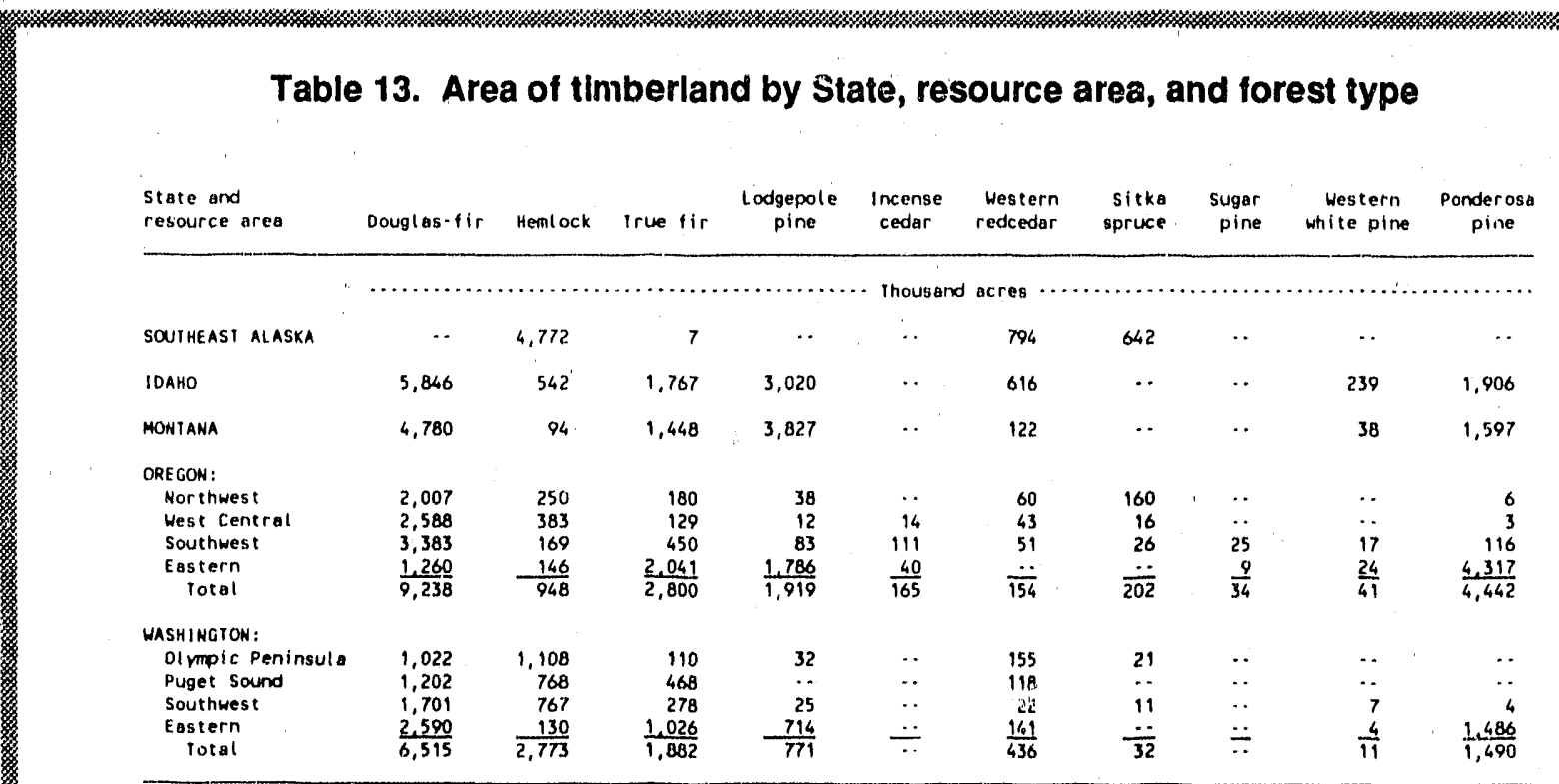

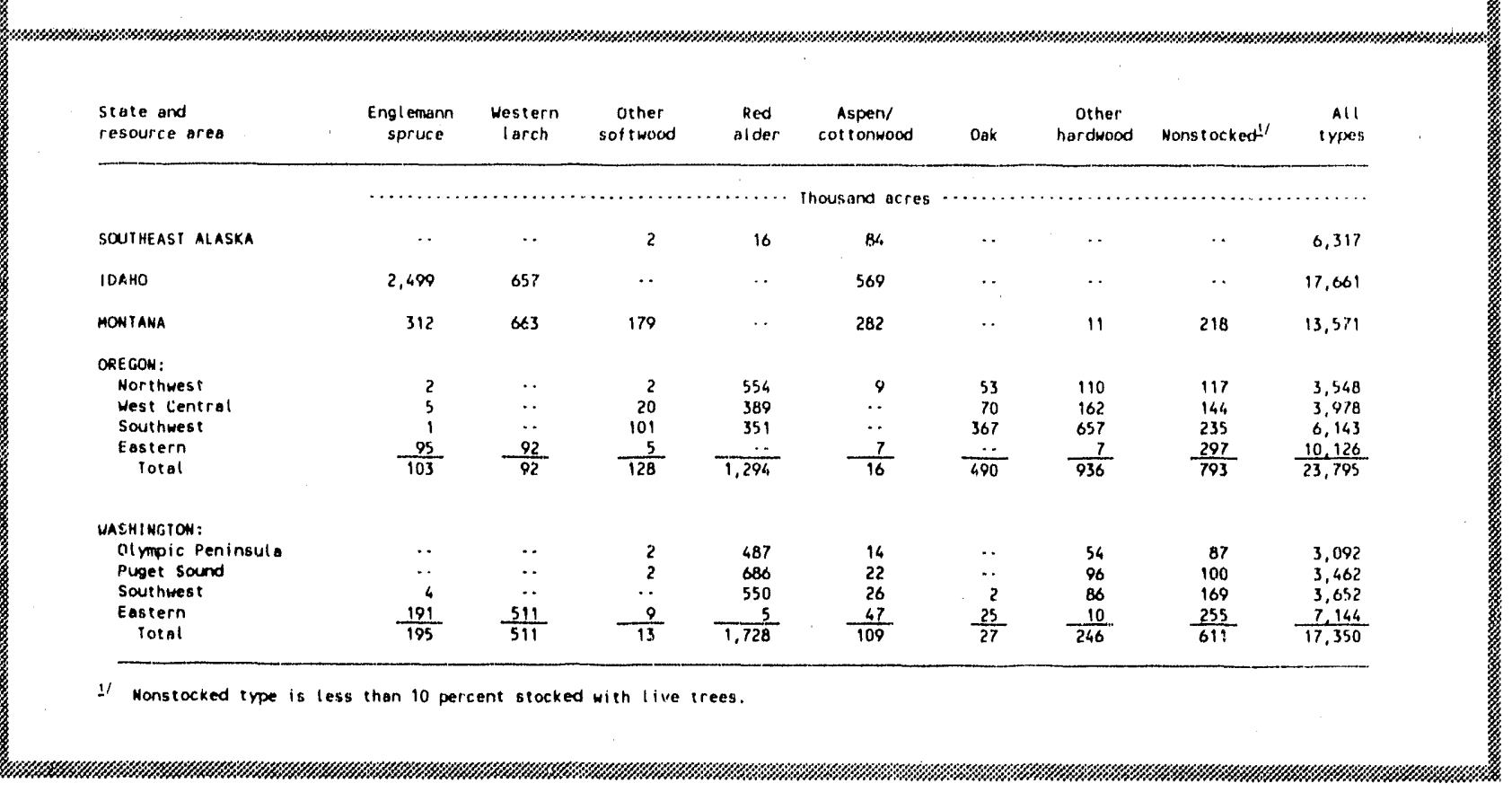


Table 14. Area of timberland by State, resource area, and cubic-foot site class

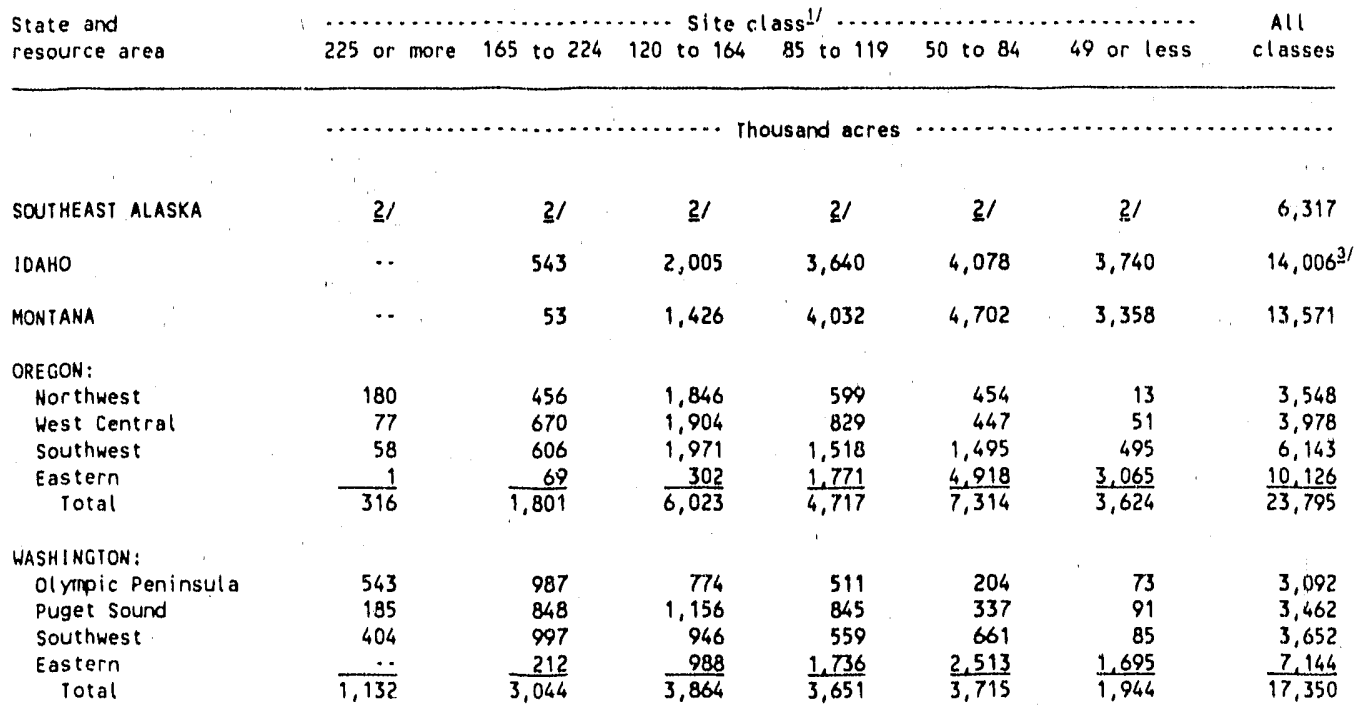

1/Relative measure of stand productivity defined by capacity for cubic-foot annual growth per acre at culmination of mean annual growth in fully stocked natural stands.

2/Breakdown by cubic. foot site class not available for Southeast Alaska.

$3 /$ Does not include $3,654,000$ acres of low productivity land not classified by site class.

Table 15. Total dry weight of above ground blomass of growing stock' trees on timberland by State, resource area, and ownership

\begin{tabular}{|c|c|c|c|c|c|}
\hline $\begin{array}{l}\text { State and } \\
\text { resource area }\end{array}$ & $\begin{array}{l}\text { National } \\
\text { Forest }\end{array}$ & $\begin{array}{l}\text { other } \\
\text { public }\end{array}$ & $\begin{array}{l}\text { Forest } \\
\text { industry }\end{array}$ & $\begin{array}{l}\text { other } \\
\text { private }\end{array}$ & $\begin{array}{c}\text { All } \\
\text { ownerships }\end{array}$ \\
\hline & \multicolumn{5}{|c|}{ Million bone dry } \\
\hline SOUTHEAST ALASKA & $\underline{2}$ & $2 /$ & 2/ & $2 /$ & 577.33 \\
\hline IDAHO & 365.29 & 56.77 & 38.55 & 55.35 & 515.96 \\
\hline MONTANA & 324.86 & 22.70 & 50.80 & 70.41 & 468.77 \\
\hline \multicolumn{6}{|l|}{ OREGON : } \\
\hline $\begin{array}{l}\text { Northwest } \\
\text { West Central } \\
\text { Southwest } \\
\text { Eastern } \\
\text { Total }\end{array}$ & $\begin{array}{l}111.27 \\
201.51 \\
184.06 \\
277.47 \\
774.31\end{array}$ & $\begin{array}{r}45.97 \\
47.43 \\
115.56 \\
25.69 \\
234.65\end{array}$ & $\begin{array}{r}55.55 \\
52.92 \\
76.93 \\
38.48 \\
223.88\end{array}$ & $\begin{array}{r}35.11 \\
28.53 \\
28.00 \\
17.39 \\
109.03\end{array}$ & $\begin{array}{r}247.90 \\
330.39 \\
404.55 \\
359.03 \\
1,341.87\end{array}$ \\
\hline \multicolumn{6}{|l|}{ WASHINGTON: } \\
\hline $\begin{array}{l}\text { Olympic Peninsula } \\
\text { Puget Sound } \\
\text { Southwest } \\
\text { Eastern } \\
\text { Total }\end{array}$ & $\begin{array}{r}51.28 \\
88.39 \\
118.27 \\
123.99 \\
381.93\end{array}$ & $\begin{array}{r}68.19 \\
51.01 \\
31.86 \\
92.30 \\
243.36\end{array}$ & $\begin{array}{r}101.43 \\
63.44 \\
88.40 \\
41.26 \\
294.53\end{array}$ & $\begin{array}{r}30.84 \\
64.47 \\
35.66 \\
43.48 \\
174.45\end{array}$ & $\begin{array}{r}251.74 \\
267.31 \\
274.19 \\
301.03 \\
1,094.27\end{array}$ \\
\hline
\end{tabular}

1 Includes trees $5,0-$ inch $d, b, h$, and larger.

2/ Breakdown by ownership class not available for Southeast Alaska. 


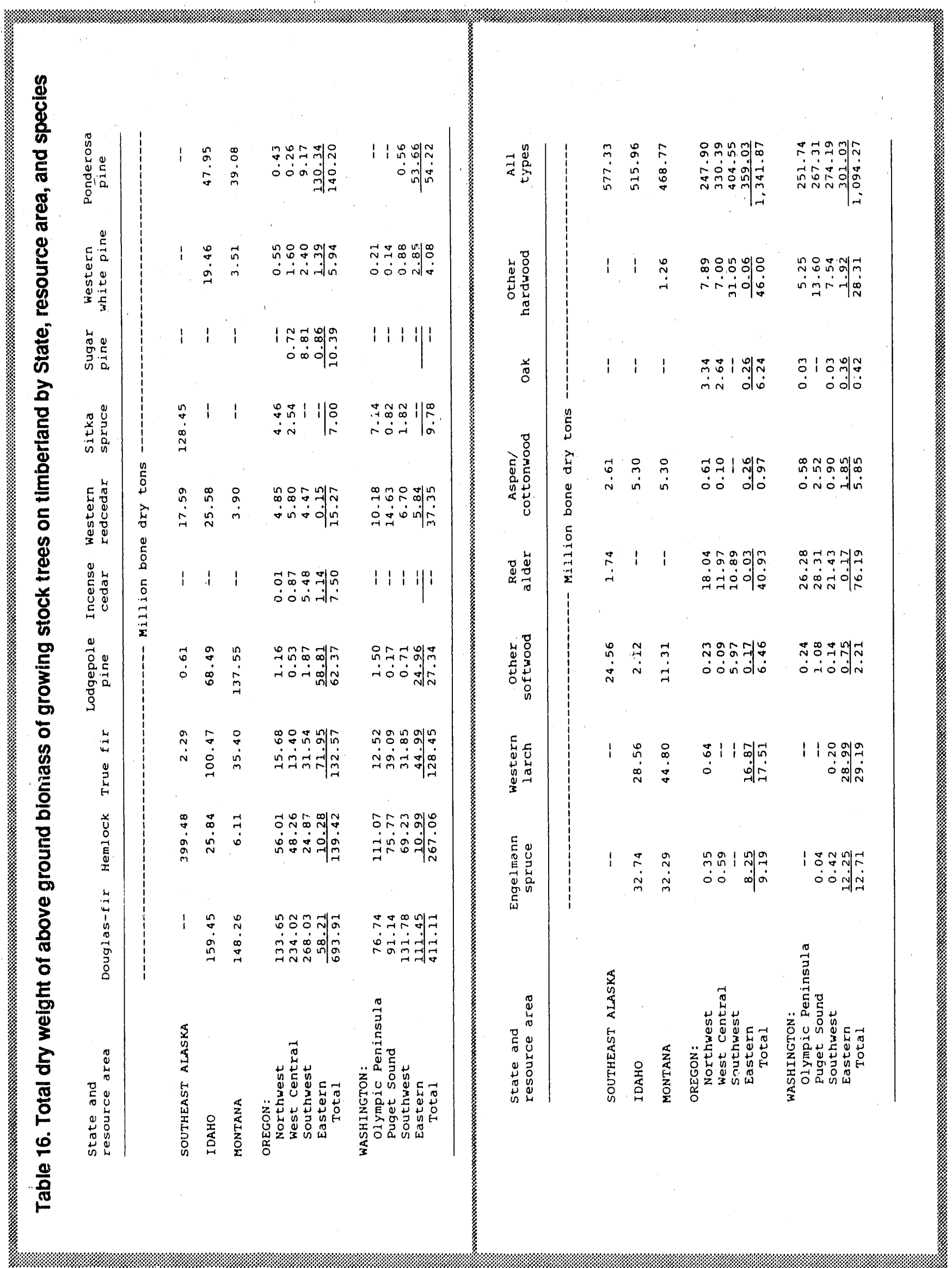


Table 17. Dry weight per acre of net annual growth of growing stock trees on timberland by State, resource area, and ownership

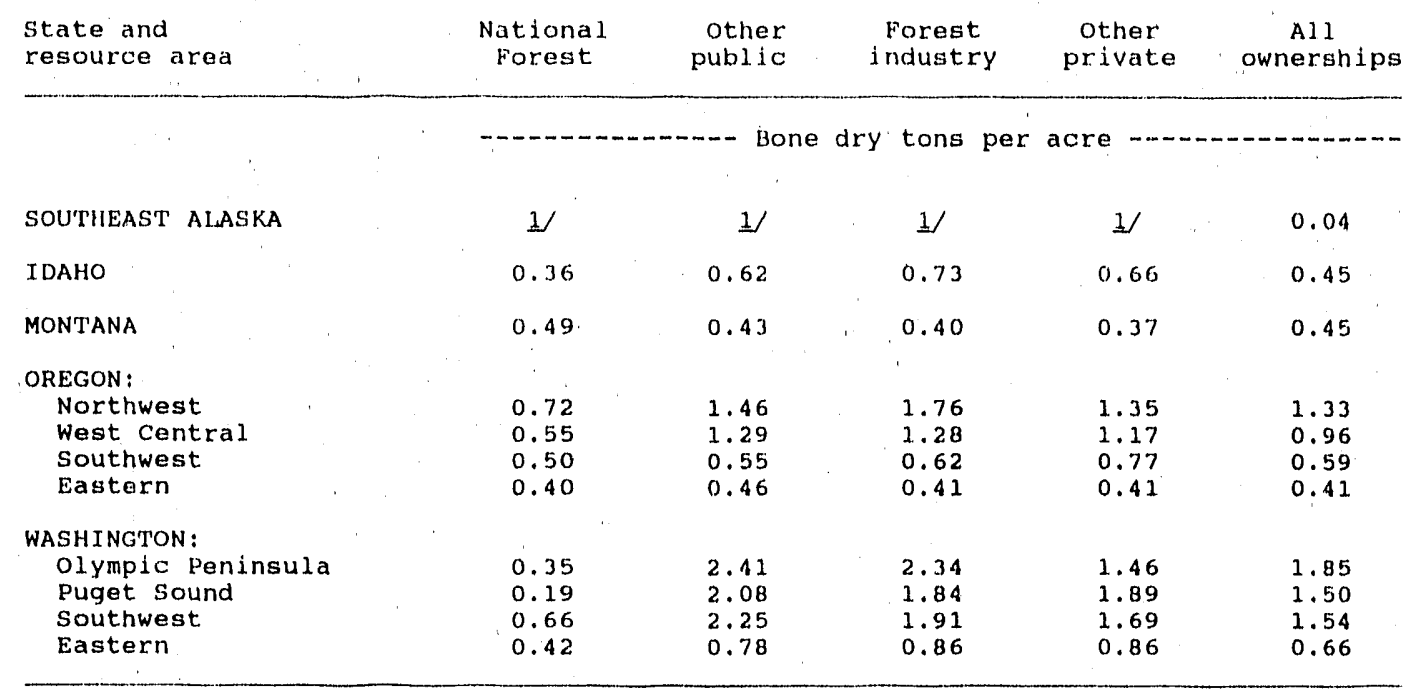

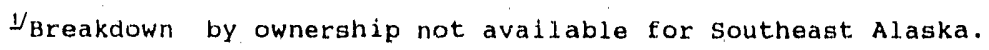

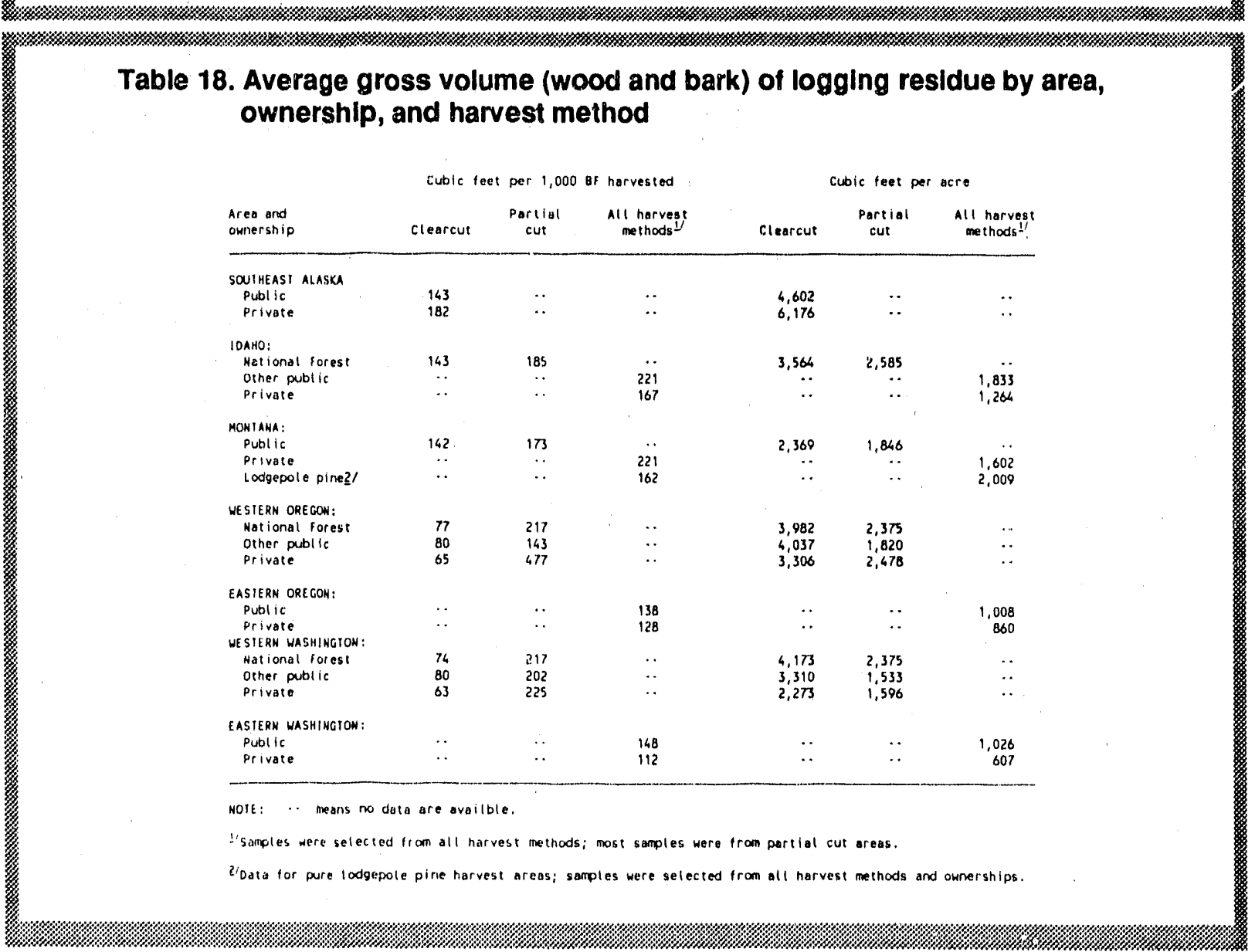


Table 19. Average net volume (wood and bark) of logging residue by area, ownership, and harvest method

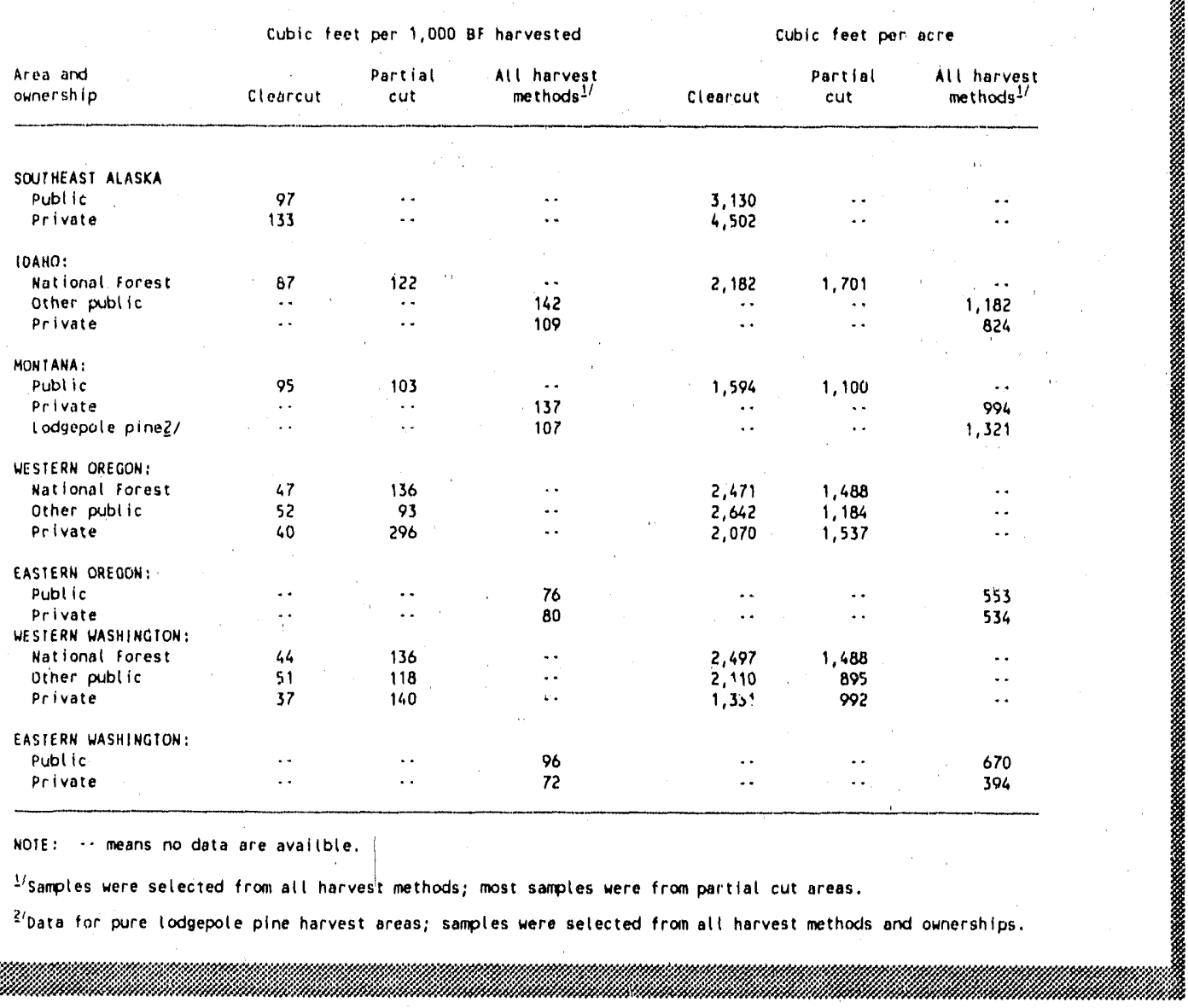

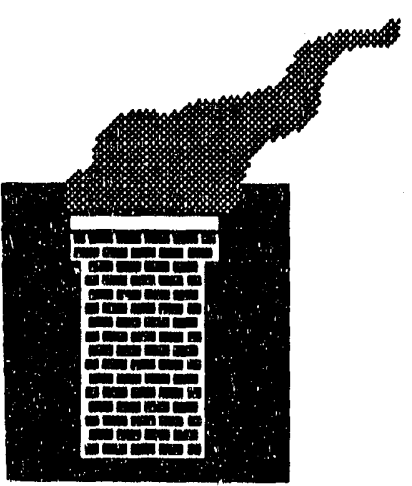


Table 20. Average net dry welght (wood and bark) of logging residue by area, ownership, and harvest method

\begin{tabular}{|c|c|c|c|c|c|c|}
\hline $\begin{array}{l}\text { Area and } \\
\text { owrership }\end{array}$ & $\begin{array}{l}\text { Borie dry } \\
\text { clearcul }\end{array}$ & $\begin{array}{l}\text { ens per } 1,0 \\
\text { Parlial } \\
\text { cul }\end{array}$ & $\begin{array}{l}\text { I harvested } \\
\text { All harvest } \\
\text { methods } 1 /\end{array}$ & Clearcut & $\begin{array}{l}\text { dry tans } \\
\text { Partial } \\
\text { cut }\end{array}$ & $\begin{array}{l}\text { All hacrest } \\
\text { methods!" }\end{array}$ \\
\hline \multicolumn{7}{|c|}{ - } \\
\hline SQUIHEASI ALASKA & & & & & & \\
\hline Publ if & 1.18 & $\cdot \cdot$ & $\cdots$ & 38.03 & . & $\cdots$ \\
\hline Frivale & 1.62 & $\cdots$ & . & 54.92 & $\cdots$ & $\cdots$ \\
\hline \multicolumn{7}{|l|}{ 10AHO: } \\
\hline Mational forest & 1.06 & 1.49 & $1 . \ddot{n}$ & 26.62 & 20.75 & $\ddot{\ddot{\theta}}$ \\
\hline Othe public & & .. & $\begin{array}{l}1.73 \\
1.33\end{array}$ & $\cdots$ & $\cdots$ & 14,42 \\
\hline Privite & ". & '. & 1,33 & $\cdots$ & $\cdots$ & 10.05 \\
\hline MONTANA: & & $\therefore$ & & & & \\
\hline Public & 1,19 & 1,29 & $\ddot{*}$ & 19.92 & 13.75 & .. \\
\hline Private & .. & .. & 1.71 & . & $\cdots$ & 12.42 \\
\hline ladgepole pine?! & $\therefore$ & . & 1.34 & * & $\cdots$ & 16.51 \\
\hline \multicolumn{7}{|l|}{ WESIERN OREGOW: } \\
\hline Hational forest & 0.62 & 1.80 & $\cdots$ & 32.62 & 19.64 & .. \\
\hline other public & 0.69 & 123 & . & 34.87 & 15.63 & .. \\
\hline Private & 0.53 & 3.41 & *. & 27.32 & 20.29 & - \\
\hline \multicolumn{7}{|l|}{ EASTERH OREGON: } \\
\hline public & .. & .. & 0.93 & . & .. & $6 . \pi 5$ \\
\hline Privale & . & . & 0.98 & $\cdots$ & . & 6.51 \\
\hline \multicolumn{7}{|l|}{ WESIERH WASHINGION: } \\
\hline Mational forest & 0.56 & 1.73 & .. & 31.71 & 18.90 & .. \\
\hline other publis & 0.65 & 1.50 & *. & 26.80 & 11.37 & .. \\
\hline Privale & 0.47 & 1.78 & $\because$ & 16.90 & 12.60 & $\cdot \cdot$ \\
\hline \multicolumn{7}{|l|}{ EASTERH WASH, IGION: } \\
\hline Public & . & $\cdot \cdot$ & 1.21 & . & $+\cdot$ & 8.44 \\
\hline Private & . & . & 0.91 & , $\cdots$ & *. & 4.96 \\
\hline
\end{tabular}

NOIE: - means no data ore availble.

:Samples were selected from all harvest methods; nost samples were from partial cut areas.

3ipata for pure lodyepole pine harvest areas; samples were selected from all harvest methods and ownerships.

Table 21. Average gross volume (wood only) of logging residue by area, ownership, harvest method, and live or dead/cull material

\begin{tabular}{|c|c|c|c|c|}
\hline $\begin{array}{l}\text { Area and } \\
\text { ownership }\end{array}$ & \multicolumn{2}{|c|}{$\begin{array}{r}\text { Live Clearcut } \\
\text { Dead/cull }\end{array}$} & \multicolumn{2}{|c|}{$\begin{array}{l}\text {-.. Partial cut' } \\
\text { Live Dead/cull }\end{array}$} \\
\hline & $\cdots$ & - Cubic & per ac & $\cdots$ \\
\hline $\begin{array}{l}\text { SOUTHEAST ALASKA } \\
\text { PUbIIC } \\
\text { Private }\end{array}$ & $\begin{array}{l}1,737 \\
2,847\end{array}$ & $\begin{array}{l}2,274 \\
2,530\end{array}$ & -- & -- \\
\hline $\begin{array}{l}\text { IDAHO: } \\
\text { National forest } \\
\text { Other public } \\
\text { Private }\end{array}$ & $\begin{array}{r}1,394 \\
\cdots \\
\cdots\end{array}$ & $\begin{array}{r}1,704 \\
--\end{array}$ & $\begin{array}{l}642 \\
412 \\
407\end{array}$ & $\begin{array}{r}1,573 \\
1,174 \\
694\end{array}$ \\
\hline $\begin{array}{l}\text { MONTANA: } \\
\text { Publ Ic } \\
\text { Private } \\
\text { Lodgepole pine }\end{array}$ & $\begin{array}{r}930 \\
--\end{array}$ & $\begin{array}{r}1,092 \\
--\end{array}$ & $\begin{array}{l}489 \\
498 \\
636\end{array}$ & $\begin{array}{r}1,089 \\
847 \\
1,180\end{array}$ \\
\hline $\begin{array}{l}\text { WESTERN OREGON: } \\
\text { National Forest } \\
\text { other public } \\
\text { Private }\end{array}$ & $\begin{array}{l}1,485 \\
1,293 \\
1,179\end{array}$ & $\begin{array}{l}1,890 \\
2,109 \\
1,627\end{array}$ & $\begin{array}{l}646 \\
555 \\
649\end{array}$ & $\begin{array}{r}1,374 \\
987 \\
1,443\end{array}$ \\
\hline $\begin{array}{l}\text { EASTERN OREGON: } \\
\text { PUblic } \\
\text { Private }\end{array}$ & $-\overline{-}$ & $=$ & $\begin{array}{l}184 \\
230\end{array}$ & $\begin{array}{l}654 \\
490\end{array}$ \\
\hline $\begin{array}{l}\text { WESTERN WASHINGTON: } \\
\text { National Forest } \\
\text { Other public } \\
\text { Private }\end{array}$ & $\begin{array}{r}1,475 \\
1,314 \\
894\end{array}$ & $\begin{array}{l}2,123 \\
1,542 \\
1,050\end{array}$ & $\begin{array}{l}646 \\
312 \\
406\end{array}$ & $\begin{array}{r}1.374 \\
989 \\
949\end{array}$ \\
\hline $\begin{array}{l}\text { EASTERN WASHINGTON: } \\
\text { Public } \\
\text { Private }\end{array}$ & $\cdots$ & $=$ & $\begin{array}{l}280 \\
183\end{array}$ & $\begin{array}{l}570 \\
325\end{array}$ \\
\hline
\end{tabular}

"Ineludes clearcuts for ownerships where the predominate method for harvesting is by partlal cutting. 
Table 22. Average gross volume (wood only) of logging residue ${ }^{1}$ per acre, by area, ownershlp, harvest method, and small-end dlameter and length class

\begin{tabular}{|c|c|c|c|c|c|c|}
\hline $\begin{array}{l}\text { Area, ownershlp, } \\
\text { and harvest } \\
\text { method }\end{array}$ & $\begin{array}{l}\text { Small-end } \\
\text { diameter }\end{array}$ & $1.0-$ & $\begin{array}{l}\text { 8.0- } \\
15.9\end{array}$ & $\begin{array}{l}\text { gth (f } \\
16.0- \\
31.9\end{array}$ & $32.0+$ & Total \\
\hline . & Inches & \multicolumn{5}{|c|}{ Cublc feet per acre } \\
\hline SOUTHEAST ALASKA & & & & & & \\
\hline $\begin{array}{l}\text { Public } \\
\text { Total }\end{array}$ & $\begin{array}{l}3.1-7.9 \\
8.0-15.9 \\
16.0-27.9 \\
28.0+\end{array}$ & $\begin{array}{l}275 \\
250 \\
174 \\
45 \\
744\end{array}$ & $\begin{array}{r}315 \\
481 \\
433 \\
119 \\
1,358\end{array}$ & $\begin{array}{r}278 \\
355 \\
513 \\
208 \\
1,354\end{array}$ & $\begin{array}{r}54 \\
63 \\
194 \\
43 \\
354\end{array}$ & $\begin{array}{r}922 \\
1,159 \\
1,314 \\
3,810\end{array}$ \\
\hline $\begin{array}{l}\text { Private } \\
\text { Total }\end{array}$ & $\begin{array}{r}3.1-7.9 \\
8.0-15.9 \\
16.0-27.9 \\
28.0+\end{array}$ & $\begin{array}{l}214 \\
164 \\
225 \\
209 \\
812\end{array}$ & $\begin{array}{r}223 \\
396 \\
347 \\
350 \\
1,316\end{array}$ & $\begin{array}{r}318 \\
471 \\
746 \\
462 \\
1,997\end{array}$ & $\begin{array}{r}177 \\
230 \\
277 \\
396 \\
1,080\end{array}$ & $\begin{array}{r}932 \\
1,261 \\
1,595 \\
1,417 \\
5,205\end{array}$ \\
\hline I DAHO & & & & & & \\
\hline $\begin{array}{l}\text { National Forest: } \\
\text { clearcut } \\
\text { Total }\end{array}$ & $\begin{array}{r}3.1-7.9 \\
8.0-15.9 \\
16.0-27.9 \\
28.0+\end{array}$ & $\begin{array}{r}50 \\
30 \\
9 \\
-15 \\
104\end{array}$ & $\begin{array}{r}112 \\
102 \\
42 \\
-7 \\
256\end{array}$ & $\begin{array}{r}231 \\
279 \\
309 \\
57 \\
876\end{array}$ & $\begin{array}{r}397 \\
310 \\
401 \\
174 \\
1,282\end{array}$ & $\begin{array}{r}790 \\
721 \\
761 \\
\quad 246 \\
2,518\end{array}$ \\
\hline $\begin{array}{l}\text { Partial cut } \\
\text { Total }\end{array}$ & $\begin{array}{l}3.1-7.9 \\
8.0-15.9 \\
16.0-27.9 \\
28.0+\end{array}$ & $\begin{array}{l}30 \\
32 \\
10 \\
10 \\
82\end{array}$ & $\begin{array}{r}112 \\
114 \\
50 \\
-= \\
276\end{array}$ & $\begin{array}{r}237 \\
288 \\
68 \\
40 \\
633\end{array}$ & $\begin{array}{r}367 \\
441 \\
357 \\
-1,165\end{array}$ & $\begin{array}{r}746 \\
875 \\
485 \\
50 \\
2,156\end{array}$ \\
\hline $\begin{array}{l}\text { other public } \\
\text { Total }\end{array}$ & $\begin{array}{l}3.1-7.9 \\
8.0-15.9 \\
16.0-27.9 \\
28.0+\end{array}$ & $\begin{array}{r}17 \\
17 \\
8 \\
2 \\
44\end{array}$ & $\begin{array}{r}54 \\
86 \\
29 \\
\quad 7 \\
176\end{array}$ & $\begin{array}{r}130 \\
194 \\
75 \\
31 \\
430\end{array}$ & $\begin{array}{l}226 \\
117 \\
264 \\
17 \\
924\end{array}$ & $\begin{array}{r}427 \\
714 \\
376 \\
57 \\
1,574\end{array}$ \\
\hline Private & $\begin{array}{l}3.1-7.9 \\
8.0-15.9 \\
16.0-27.9 \\
28.0+\end{array}$ & $\begin{array}{r}24 \\
19 \\
7 \\
-=\end{array}$ & $\begin{array}{r}83 \\
65 \\
29 \\
-177\end{array}$ & $\begin{array}{r}171 \\
139 \\
80 \\
-7 \\
390\end{array}$ & $\begin{array}{r}219 \\
153 \\
52 \\
42 \\
466\end{array}$ & $\begin{array}{r}497 \\
376 \\
168 \\
-\quad 42 \\
1,083\end{array}$ \\
\hline
\end{tabular}

MONTANA "

\begin{tabular}{crrrrrr}
$\begin{array}{c}\text { National Forest: } \\
\text { Clearcut }\end{array}$ & $3.1-7.9$ & 234 & 246 & 276 & 155 & 911 \\
& $8.0-15.9$ & 131 & 117 & 110 & 79 & 437 \\
& $16.0-19.9$ & 21 & 43 & 37 & 19 & 120 \\
Total & $20.0+$ & $\frac{21}{407}$ & $\frac{18}{424}$ & $\frac{51}{474}$ & $\frac{15}{268}$ & $\frac{105}{1.573}$ \\
Partial cut & & & & & & \\
& $3.1-7.9$ & 137 & 182 & 219 & 213 & 751 \\
& $8.0-15.9$ & 87 & 109 & 128 & 102 & 426 \\
Total & $16.0-19.9$ & 10 & 24 & 29 & 47 & 110 \\
& $20.0+$ & $\frac{19}{253}$ & $\frac{31}{346}$ & $\frac{32}{408}$ & $\frac{20}{382}$ & $\frac{102}{389}$ \\
\hline
\end{tabular}

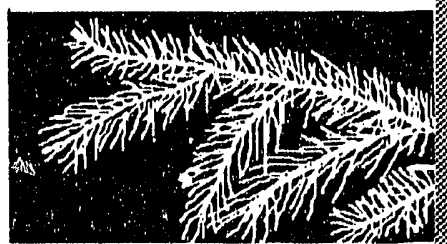


Table 22. Average gross volume (wood only) of logging residue ' per acre, by area, ownership, harvest mothod, and small-end diameter and length class (continued)

\begin{tabular}{|c|c|c|c|c|c|c|}
\hline $\begin{array}{l}\text { Area, ownership, } \\
\text { and harvest } \\
\text { method }\end{array}$ & $\begin{array}{l}\text { Small-end } \\
\text { diameter }\end{array}$ & $\begin{array}{l}-.1 .- \\
1.0- \\
7.9\end{array}$ & $\begin{array}{l}8.0- \\
15.9\end{array}$ & $\begin{array}{l}\text { igth } \\
16.0- \\
31.9\end{array}$ & $32.0+$ & Total \\
\hline & Inches & $\cdots$ & - cuk & feet & r acre & $\cdots$ \\
\hline \multicolumn{7}{|l|}{ MONTANA (Continued) } \\
\hline $\begin{array}{l}\text { Other public } \\
\text { Total }\end{array}$ & $\begin{array}{l}3.1-7.9 \\
8.0-15.9 \\
16.0-19.9 \\
20.0+\end{array}$ & $\begin{array}{r}125 \\
90 \\
19 \\
55 \\
289\end{array}$ & $\begin{array}{r}153 \\
86 \\
13 \\
14 \\
266\end{array}$ & $\begin{array}{r}152 \\
78 \\
32 \\
32 \\
291\end{array}$ & $\begin{array}{r}73 \\
50 \\
8 \\
32 \\
153\end{array}$ & $\begin{array}{r}503 \\
304 \\
72 \\
\quad 133 \\
1,012\end{array}$ \\
\hline $\begin{array}{l}\text { Lodgepole pine } \\
\text { Total }\end{array}$ & $\begin{array}{l}3.1-7.9 \\
8.0-15.9 \\
26.0-19.9 \\
20.0+\end{array}$ & $\begin{array}{r}237 \\
86 \\
7 \\
0 \\
330\end{array}$ & $\begin{array}{r}226 \\
71 \\
21 \\
15 \\
333\end{array}$ & $\begin{array}{r}309 \\
80 \\
16 \\
-7 \\
05\end{array}$ & $\begin{array}{r}177 \\
35 \\
3 \\
15 \\
230\end{array}$ & $\begin{array}{r}949 \\
272 \\
17 \\
\quad 30 \\
1,250\end{array}$ \\
\hline
\end{tabular}

WESTERN OREGON

\begin{tabular}{|c|c|c|c|c|c|c|}
\hline clearcut & $\begin{array}{l}3.1-7.9 \\
8.0-15.9 \\
16.0-27.9 \\
28.0+\end{array}$ & $\begin{array}{r}60 \\
157 \\
105 \\
-\frac{42}{364}\end{array}$ & $\begin{array}{r}122 \\
312 \\
269 \\
46 \\
749\end{array}$ & $\begin{array}{r}235 \\
244 \\
592 \\
226 \\
1,297\end{array}$ & $\begin{array}{l}130 \\
265 \\
250 \\
174 \\
819\end{array}$ & $\begin{array}{r}547 \\
978 \\
1,216 \\
488 \\
3,229\end{array}$ \\
\hline $\begin{array}{l}\text { Partial cut } \\
\text { Total }\end{array}$ & $\begin{array}{l}3.1-7.9 \\
8.0-15.9 \\
16.0-27.9 \\
28.0+\end{array}$ & $\begin{array}{r}18 \\
34 \\
16 \\
6 \\
74\end{array}$ & $\begin{array}{r}49 \\
90 \\
90 \\
40 \\
269\end{array}$ & $\begin{array}{r}91 \\
164 \\
275 \\
136 \\
666\end{array}$ & $\begin{array}{r}74 \\
197 \\
452 \\
223 \\
946\end{array}$ & $\begin{array}{r}232 \\
185 \\
833 \\
405 \\
1,955\end{array}$ \\
\hline $\begin{array}{l}\text { Other public: } \\
\text { clearcut } \\
\text { Total }\end{array}$ & $\begin{array}{l}3.1-7.9 \\
8.0-15.9 \\
16.0-27.9 \\
28.0+\end{array}$ & $\begin{array}{r}12 \\
77 \\
29 \\
\quad 6 \\
153\end{array}$ & $\begin{array}{l}154 \\
210 \\
172 \\
97 \\
633\end{array}$ & $\begin{array}{r}275 \\
395 \\
239 \\
390 \\
1,299\end{array}$ & $\begin{array}{r}243 \\
433 \\
356 \\
210 \\
1,242\end{array}$ & $\begin{array}{r}713 \\
1,115 \\
796 \\
703 \\
3,327\end{array}$ \\
\hline Partis: cut & $\begin{array}{l}3.1-7.9 \\
8.0-15.9 \\
16.0-27.9 \\
28.0+\end{array}$ & $\begin{array}{r}15 \\
25 \\
13 \\
4 \\
57\end{array}$ & $\begin{array}{r}53 \\
56 \\
61 \\
18 \\
185\end{array}$ & $\begin{array}{r}115 \\
112 \\
136 \\
65 \\
128\end{array}$ & $\begin{array}{l}135 \\
186 \\
316 \\
201 \\
838\end{array}$ & $\begin{array}{r}318 \\
379 \\
526 \\
-285 \\
1,508\end{array}$ \\
\hline \multicolumn{7}{|l|}{ Private: } \\
\hline clearcut & $\begin{array}{l}3.1-7.9 \\
8.0-15.9 \\
16.0-27.9 \\
28.0+\end{array}$ & $\begin{array}{r}31 \\
55 \\
40 \\
30 \\
156\end{array}$ & $\begin{array}{r}77 \\
137 \\
213 \\
67 \\
174\end{array}$ & $\begin{array}{r}161 \\
229 \\
422 \\
406 \\
1,218\end{array}$ & $\begin{array}{l}151 \\
187 \\
351 \\
239 \\
928\end{array}$ & $\begin{array}{r}120 \\
608 \\
1,026 \\
-722 \\
2,776\end{array}$ \\
\hline Partial cut & $\begin{array}{l}3.1-7.9 \\
8.0-15.9 \\
26.0-27.9 \\
28.0+\end{array}$ & $\begin{array}{l}20 \\
22 \\
28 \\
1 \\
64\end{array}$ & $\begin{array}{r}57 \\
77 \\
94 \\
55 \\
283\end{array}$ & $\begin{array}{r}114 \\
157 \\
236 \\
140 \\
647\end{array}$ & $\begin{array}{r}93 \\
204 \\
126 \\
370 \\
1,093\end{array}$ & $\begin{array}{r}284 \\
460 \\
774 \\
569 \\
2,087\end{array}$ \\
\hline
\end{tabular}

EASTERN OREGON

\begin{tabular}{|c|c|c|c|c|c|c|}
\hline $\begin{array}{l}\text { Public } \\
\text { Total }\end{array}$ & $\begin{array}{l}3.1-7.9 \\
8.0-15.9 \\
16.0-27.9 \\
28.0+\end{array}$ & $\begin{array}{r}11 \\
12 \\
6 \\
-10\end{array}$ & $\begin{array}{l}30 \\
35 \\
24 \\
21 \\
100\end{array}$ & $\begin{array}{r}48 \\
71 \\
71 \\
40 \\
230\end{array}$ & $\begin{array}{r}115 \\
214 \\
110 \\
39 \\
178\end{array}$ & $\begin{array}{r}204 \\
332 \\
211 \\
91 \\
838\end{array}$ \\
\hline $\begin{array}{l}\text { Private } \\
\text { Total }\end{array}$ & $\begin{array}{l}3.2-7.9 \\
8.0-15.9 \\
26.0-27.9 \\
28.0+\end{array}$ & $\begin{array}{r}27 \\
11 \\
4 \\
33\end{array}$ & $\begin{array}{r}54 \\
25 \\
20 \\
\quad 3 \\
102\end{array}$ & $\begin{array}{r}72 \\
48 \\
53 \\
-2 \\
173\end{array}$ & $\begin{array}{r}104 \\
130 \\
117 \\
59 \\
410\end{array}$ & $\begin{array}{r}21 \\
19 \\
6 \\
71\end{array}$ \\
\hline
\end{tabular}


Table 22. Average gross volume (wood enly) of logging residue ' per acre, by area, ownership, harvest method, and small-end dlameter and length class (conilnised)

\begin{tabular}{|c|c|c|c|c|c|}
\hline $\begin{array}{l}\text { Area, ownership, } \\
\text { and harvest } \\
\text { method }\end{array}$ & $\begin{array}{l}\text { Small-end } \\
\text { diameter }\end{array}$ & $\begin{array}{l}1.0- \\
7.9\end{array}$ & $\begin{array}{r}8.0- \\
25.9\end{array}$ & $\begin{array}{l}16.0- \\
31.9\end{array}$ & $32.0+$ \\
\hline
\end{tabular}

WESTERN WASHINGTON

National Forest:

clearcut.

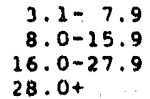

$\begin{array}{r}58 \\ 136 \\ 120 \\ 32 \\ \hline 346\end{array}$

$\begin{array}{r}174 \\ 368 \\ 363 \\ 129 \\ \hline 1,024\end{array}$

236
260
761

Total 1

$3.1-7.9$

$8.0-15.9$

$16.0-27.9$

$28.0+$

$\begin{array}{r}18 \\ 34 \\ 16 \\ -6 \\ \hline 74\end{array}$

$\begin{array}{r}49 \\ 90 \\ 90 \\ 40 \\ \hline 269\end{array}$

$\frac{163}{1,420}$

54
269

$376 \quad 1,620$

$3.1-7.9$
$8.0-15.9$
$16.0-27.9$

Total

$28.0+$

\begin{tabular}{rr}
16 & 125 \\
67 & 178 \\
59 & 263 \\
20 & -164 \\
\hline
\end{tabular}

91

91
164
275
236

599

$\frac{324}{3,389}$

$74 \quad 232$

$197 \quad 485$

452

$\frac{223}{946}$

$\begin{array}{r}833 \\ 405 \\ \hline 1,955\end{array}$

other public:

Partial cut.

$3.1-7.9$

8. $0-15.9$

$16.0-27.9$

Total

28.04

\begin{tabular}{rr}
22 & 67 \\
22 & 34 \\
2 & 36 \\
-5 & 97 \\
\hline 46 & 234
\end{tabular}
221
359
$\begin{array}{r}359 \\ -366 \\ \hline\end{array}$

105

88
274
269
736

497

541

955

$\frac{019}{2,812}$

Private:

clarcut

$3.1-7.9$
$8.0-15.9$
$16.0-27.9$

Total

$$
28.0+
$$

\begin{tabular}{rr}
47 & 142 \\
69 & 178 \\
36 & 92 \\
7 & 67 \\
\hline 159 & 479
\end{tabular}

$\begin{array}{r}170 \\ 115 \\ 59 \\ 283 \\ \hline 527\end{array}$

147
45
214
88

406

$45 \quad 216$

$\frac{88}{494} \quad-369$

Partial cut

$3.1-7.9$

8.0-15.9

$16.0-27.9$

$28.0+$

Total

$\begin{array}{rr}26 & 89 \\ 18 & 117 \\ 14 & 10 \\ -- & =-\end{array}$

238
217
159
296
810

203
117
148
130
598

60
139
150

$\frac{122}{460}$

487

$\begin{array}{r}137 \\ 382 \\ \hline\end{array}$

271589

$\begin{array}{rr}271 & 589 \\ 51 & 303 \\ 70 & 272\end{array}$

$\frac{59}{451} \quad \frac{289}{1.353}$

EASTERN WASHINGTON

Public

Total

3. $1-7.9$

$8.0-15.9$
$16.0-27.9$

$28.0+$

16
14
5
$\frac{1}{36}$

$\begin{array}{r}18 \\ 41 \\ 15 \\ 8 \\ \hline 112\end{array}$

$\begin{array}{r}66 \\ 202 \\ 68 \\ 22 \\ \hline 258\end{array}$

106
154
130
2.8
418

$\begin{array}{r}236 \\ 311 \\ 218 \\ 5.9 \\ \hline 824\end{array}$

Private

3.1- 7.9

8. $0-15.9$

$16.0-27.9$

$28.0+$

\begin{tabular}{rr}
11 & 36 \\
11 & 23 \\
5 & 13 \\
2 & -6 \\
\hline 29 & 78
\end{tabular}

$\begin{array}{r}85 \\ 47 \\ 52 \\ 9 \\ \hline 193\end{array}$

\begin{tabular}{rr}
70 & 202 \\
58 & 139 \\
56 & 126 \\
8 & -25 \\
\hline 192 & 492
\end{tabular}

Total

Doos not include residue in large piles.

isampling by diameter classes was different in Montana than that

in the other states. 
Table 23. Average number of pleces of logging residue ' per acre, by area, ownership, harvest method, and small-end diameter and length class

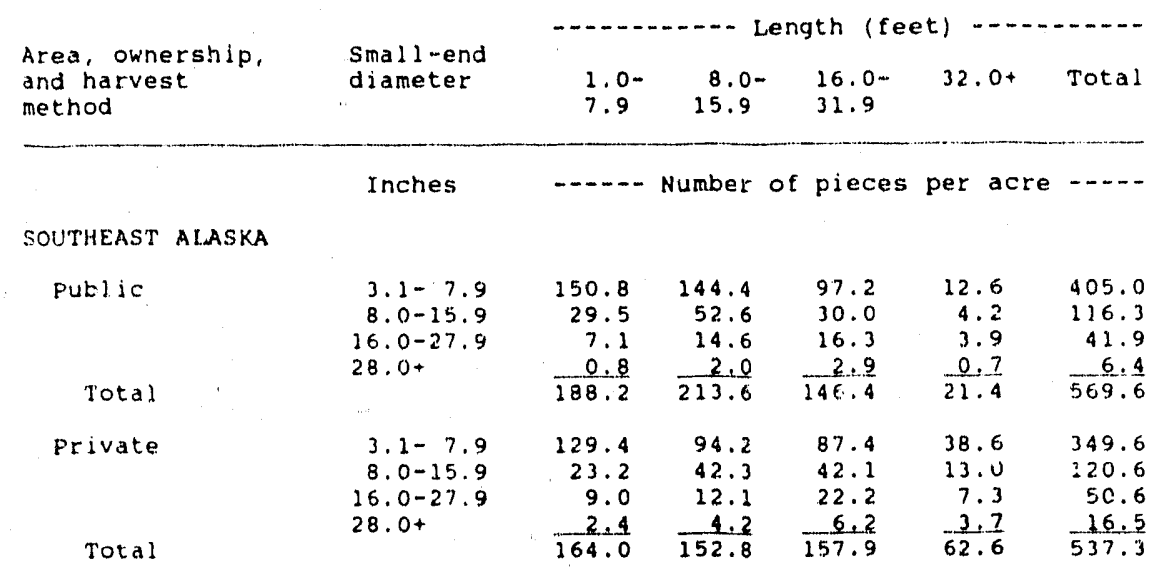

IDAHO

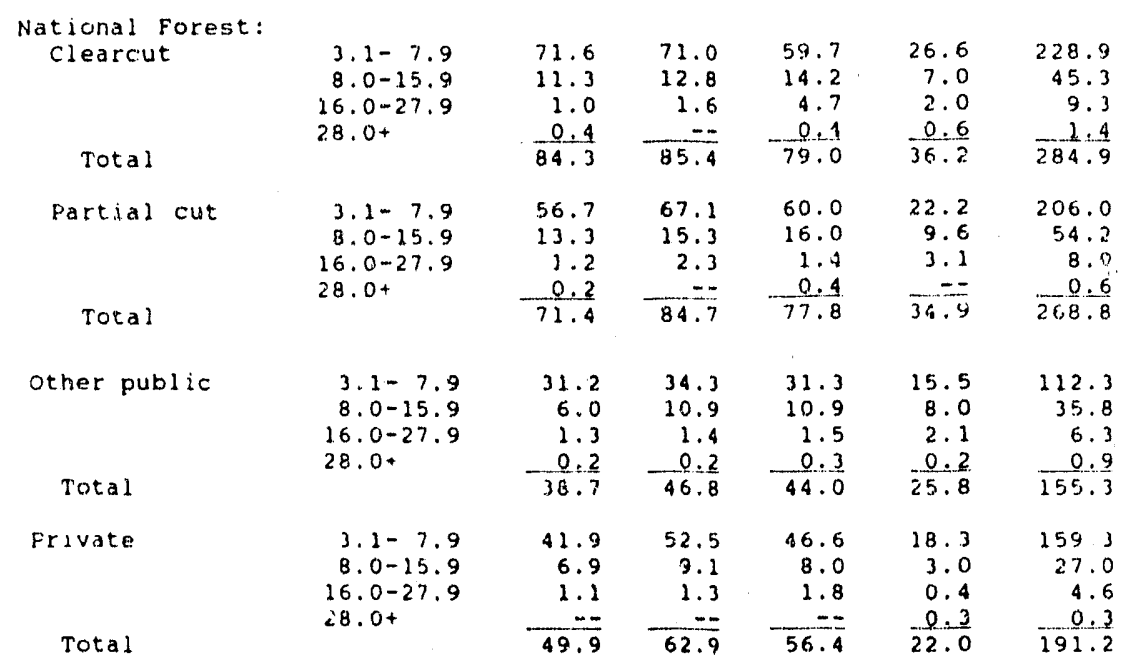

MONTANA ${ }^{i}$

National foreit:

clearcut

$3.1-7.9$

8. $0-15.9$

$16.0-27.9$

$28.0+$

Total

$3.1-7.3$

$3.1-7.3$
$8.0-15.9$

$26.0-27.9$

$28.0+$

$\begin{array}{r}182.7 \\ 19.2 \\ 1.2 \\ 0.6 \\ \hline 203.6 \\ 103.6 \\ 12.6 \\ 0.6 \\ 0.5 \\ \hline 17.3\end{array}$

$\begin{array}{r}166.2 \\ 14.9 \\ 2.2 \\ 183.5 \\ 117.8 \\ 13.3 \\ 1.3 \\ 12.0 \\ \hline 133.4\end{array}$

168.5

12.8
1.5

1.5
1.4
184.2

66.7

66.7
6.7

0.9

$\frac{0.5}{74.8}$

584.1

53.5

5.8

64.0

Partial cue

(1)

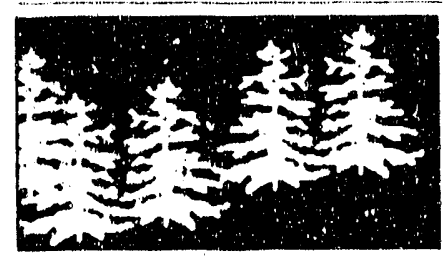

117.5

16.3

73.7

73.7
9.2

9.2
1.7

$\begin{array}{ll}0.7 & \frac{0.4}{135.9} \quad \frac{2.6}{85.0}\end{array}$

412.6

51.4

5.0

(1.
135.9 $\frac{0.4}{85.0} \quad \frac{2.6}{471.6}$ 
Table 23. Average number of pieces of logging residue ${ }^{\prime}$ per acre, by area, ownership, harvest method, and small-end diameter and length class (continued)

\begin{tabular}{|c|c|c|c|c|c|c|}
\hline $\begin{array}{l}\text { Area ownership, } \\
\text { and harvest } \\
\text { method }\end{array}$ & $\begin{array}{l}\text { Small-end } \\
\text { diameter }\end{array}$ & $\begin{array}{l}1.0- \\
7.9\end{array}$ & $\begin{array}{l}8.0- \\
15.9\end{array}$ & $\begin{array}{l}16.0- \\
31.9\end{array}$ & $32.0+$ & Total \\
\hline & Inches & $\cdots-\cdots$ & Number & pieces & per acre & -- \\
\hline \multicolumn{7}{|c|}{ MONTANA ${ }^{\prime \prime}$ (Continued) } \\
\hline other public & $\begin{array}{l}3.1-7.9 \\
8.0-15.9 \\
16.0-27.9 \\
28.0+\end{array}$ & $\begin{array}{r}100.1 \\
12.0 \\
0.9 \\
1.3 \\
114.3\end{array}$ & $\begin{array}{r}93.6 \\
11.0 \\
0.7 \\
0.4 \\
105.7\end{array}$ & $\begin{array}{r}87.2 \\
8.7 \\
1.3 \\
0.8 \\
98.0\end{array}$ & $\begin{array}{r}29.7 \\
4.8 \\
0.4 \\
0.6 \\
35.5\end{array}$ & $\begin{array}{r}310.6 \\
36.5 \\
3.3 \\
3.1 \\
353.5\end{array}$ \\
\hline Lodgepole pine & $\begin{array}{l}3.1-7.9 \\
8.0-15.9 \\
16.0-27.9 \\
28.0+\end{array}$ & $\begin{array}{r}190.4 \\
14.5 \\
0.5 \\
205.4\end{array}$ & $\begin{array}{r}159.4 \\
9.8 \\
0.7 \\
0.3 \\
170.2\end{array}$ & $\begin{array}{r}181.5 \\
10.5 \\
0.8 \\
--. \\
192.8\end{array}$ & $\begin{array}{r}74.9 \\
3.8 \\
0.2 \\
0.5 \\
79.4\end{array}$ & $\begin{array}{r}606.2 \\
38.6 \\
2.2 \\
0.8 \\
647.8\end{array}$ \\
\hline
\end{tabular}

WESTERN ORESON

\begin{tabular}{|c|c|c|c|c|c|c|}
\hline clearcut & $\begin{array}{l}3.1-7.9 \\
8.0-15.9 \\
16.0-27.9 \\
2.8 .0+\end{array}$ & $\begin{array}{r}97.7 \\
50.3 \\
11.2 \\
1.8 \\
161.0\end{array}$ & $\begin{array}{r}72.0 \\
37.2 \\
10.5 \\
0.7 \\
120.4\end{array}$ & $\begin{array}{r}58.7 \\
15.4 \\
9.6 \\
2.4 \\
85.1\end{array}$ & $\begin{array}{r}28.3 \\
4.0 \\
2.8 \\
0.7 \\
25.8\end{array}$ & $\begin{array}{r}246.7 \\
106.9 \\
34.1 \\
\quad 1.6 \\
392.3\end{array}$ \\
\hline $\begin{array}{l}\text { Partial cut } \\
\text { rotal }\end{array}$ & $\begin{array}{l}3.1-7.9 \\
8.0-15.9 \\
16.0-27.9 \\
28.0+\end{array}$ & $\begin{array}{r}28.6 \\
11.6 \\
2.2 \\
0.3 \\
42.7\end{array}$ & $\begin{array}{r}27.5 \\
10.3 \\
3.7 \\
0.5 \\
12.0\end{array}$ & $\begin{array}{r}21.4 \\
8.7 \\
4.6 \\
1.0 \\
35.7\end{array}$ & $\begin{array}{r}5.3 \\
3.4 \\
3.5 \\
0.6 \\
12.8\end{array}$ & $\begin{array}{r}82.8 \\
34.0 \\
14.0 \\
2.4 \\
133.2\end{array}$ \\
\hline $\begin{array}{l}\text { Other public: } \\
\text { clearcut } \\
\text { Total }\end{array}$ & $\begin{array}{l}3.1-7.9 \\
8.0-15.9 \\
16.0-27.9 \\
28.0+\end{array}$ & $\begin{array}{r}74.8 \\
27.3 \\
3.3 \\
0.8 \\
105.8\end{array}$ & $\begin{array}{r}97.4 \\
27.2 \\
6.9 \\
7.7 \\
133.2\end{array}$ & $\begin{array}{r}69.6 \\
20.8 \\
4.7 \\
2.2 \\
97.2\end{array}$ & $\begin{array}{r}23.0 \\
7.2 \\
2.7 \\
0.8 \\
33.7\end{array}$ & $\begin{array}{r}264.8 \\
82.5 \\
17.6 \\
5.0 \\
369.9\end{array}$ \\
\hline Partial cut & $\begin{array}{l}3.1-7.9 \\
8.0-15.9 \\
16.0-27.9 \\
28.0+\end{array}$ & $\begin{array}{r}29.0 \\
9.7 \\
1.3 \\
0.2 \\
40.2\end{array}$ & $\begin{array}{r}36.3 \\
8.1 \\
2.1 \\
0.2 \\
17.0\end{array}$ & $\begin{array}{r}30.8 \\
6.3 \\
2.7 \\
0.1 \\
10.2\end{array}$ & $\begin{array}{r}9.8 \\
3.8 \\
2.3 \\
0.7 \\
16.6\end{array}$ & $\begin{array}{r}105.9 \\
27.9 \\
8.7 \\
1.5 \\
144.0\end{array}$ \\
\hline
\end{tabular}

Private:

clearcut

$3.1-7.9$
$8.0-15.9$
$16.0-27.9$

48.0

18.8

$28.0+$

Total

$\frac{0.2}{72.0}$

17.1
19.2
8.2
0.

.1
8.1
0.2
0.8
5.5

40.

$13 \quad 12.4 \quad 248.0$

$\begin{array}{rrr}13.2 & 3.8 & 54.9 \\ 7.3 & 3.0 & 22.8\end{array}$

Partial cut

$3.1-7.9$

$8.0-15.9$

36.6

36.6
7.5

2.2

40.2

$\frac{2.3}{63.0}$

ค. 7

$\frac{4.7}{230.4}$

Tozal

$26.0+$

$\frac{0.2}{46.5}$

$\begin{array}{ll}9.3 & 9.0 \\ 3.8 & 3.8\end{array}$

32.1

$9.5 \quad 128.4$

$\frac{1.8}{54.3}$

3.8

$2.9 \quad 28.7$

$3.4 \quad 13.2$

EASTERN OREGON

Public

Total

$3.1-7.9$ $8.0-15.9$
$16.0-27.9$

$28.0+$

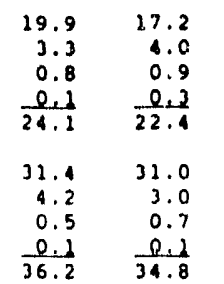

$3.1-7.9$

8. $0-15.9$

$15.0-27.9$

$28.0+$

Total

$\frac{0.2}{36.2}$

$\frac{0.2}{34.8}$

\begin{tabular}{rrr}
9.8 & 4.7 & 51.6 \\
3.0 & 2.2 & 12.5 \\
1.2 & 0.8 & 3.7 \\
0.3 & 0.1 & -0.8 \\
\hline 14.3 & 7.8 & 68.6 \\
17.7 & 5.3 & 85.4 \\
2.6 & 1.6 & 11.4 \\
1.0 & 0.5 & 2.7 \\
-1.5 & 0.2 & 0.4 \\
\hline 21.3 & 7.6 & 99.9
\end{tabular}


Table 23. Average number of pleces of logging residue ' per acre, by area, ownership, harvest method, and small-end dlameter and length class (continued)

\begin{tabular}{|c|c|c|c|c|c|c|}
\hline $\begin{array}{l}\text { Area, ownership, } \\
\text { and harvest } \\
\text { method }\end{array}$ & $\begin{array}{l}\text { Small-end } \\
\text { diameter }\end{array}$ & $7.0-$ & $\begin{array}{c}8.0- \\
15.9\end{array}$ & $\begin{array}{l}\text { gth (fe } \\
16.0- \\
31.9\end{array}$ & $32.0+$ & Total \\
\hline & Inches & $\ldots$ & Number 0 & pieces & per acre & $\cdots$ \\
\hline \multicolumn{7}{|l|}{ WESTERN WASHINGTON } \\
\hline $\begin{array}{l}\text { National Forest: } \\
\text { Clearcut } \\
\text { Total }\end{array}$ & $\begin{array}{l}3.1-7.9 \\
8.0-15.9 \\
16.0-27.9 \\
28.0+\end{array}$ & $\begin{array}{r}88.9 \\
46.3 \\
11.5 \\
\quad 1.4 \\
148.1\end{array}$ & $\begin{array}{r}86.9 \\
44.0 \\
15.4 \\
2.1 \\
148.4\end{array}$ & $\begin{array}{l}54.4 \\
14.8 \\
12.9 \\
1.1 \\
83.2\end{array}$ & $\begin{array}{r}5.3 \\
3.3 \\
3.7 \\
-. \\
12.3\end{array}$ & $\begin{array}{r}235.5 \\
108.4 \\
43.5 \\
4.6 \\
392.0\end{array}$ \\
\hline $\begin{array}{l}\text { Partial cut } \\
\text { Total }\end{array}$ & $\begin{array}{l}3.1-7.9 \\
8.0-15.9 \\
16.0-27.9 \\
28.0+\end{array}$ & $\begin{array}{r}28.6 \\
11.6 \\
2.2 \\
0.3 \\
12.7\end{array}$ & $\begin{array}{r}27.5 \\
20.3 \\
3.7 \\
0.5 \\
12.0\end{array}$ & $\begin{array}{r}21.4 \\
8.7 \\
4.6 \\
1.0 \\
35.7\end{array}$ & $\begin{array}{r}5.3 \\
3.4 \\
3.5 \\
0.6 \\
12.8\end{array}$ & $\begin{array}{r}82.8 \\
34.0 \\
1.4 .0 \\
\quad 2.4 \\
133.2\end{array}$ \\
\hline $\begin{array}{c}\text { Other public: } \\
\text { Clearcut } \\
\text { Total }\end{array}$ & $\begin{array}{l}3.1-7.9 \\
8.0-15.9 \\
16.0-27.9 \\
28.0+\end{array}$ & $\begin{array}{r}82.9 \\
24.8 \\
7.1 \\
0.7 \\
115.5\end{array}$ & $\begin{array}{r}81.1 \\
25.5 \\
10.0 \\
2.1 \\
118.7\end{array}$ & $\begin{array}{r}62.4 \\
14.4 \\
6.0 \\
2.2 \\
85.0\end{array}$ & $\begin{array}{r}14.3 \\
2.2 \\
2.1 \\
0.8 \\
19.4\end{array}$ & $\begin{array}{r}240.7 \\
66.9 \\
25.2 \\
5.8 \\
338.6\end{array}$ \\
\hline Partial cut & $\begin{array}{l}3.1-7.9 \\
8.0-15.9 \\
16.0-27.9 \\
28.0+\end{array}$ & $\begin{array}{r}50.0 \\
5.7 \\
0.4 \\
\quad-. \\
56.1\end{array}$ & $\begin{array}{r}55.2 \\
4.2 \\
1.2 \\
1.2 \\
61.8\end{array}$ & $\begin{array}{r}55.6 \\
6.9 \\
1.2 \\
0.8 \\
64.5\end{array}$ & $\begin{array}{r}18.1 \\
1.2 \\
1.6 \\
0.4 \\
21.3\end{array}$ & $\begin{array}{r}178.9 \\
18.0 \\
4.4 \\
2.4 \\
203.7\end{array}$ \\
\hline $\begin{array}{l}\text { Private: } \\
\text { Clearcut } \\
\text { Total }\end{array}$ & $\begin{array}{l}3.1-7.9 \\
8.0-15.9 \\
16.0-27.9 \\
28.0+\end{array}$ & $\begin{array}{r}77.7 \\
24.8 \\
3.5 \\
0.2 \\
206.2\end{array}$ & $\begin{array}{r}80.1 \\
24.4 \\
3.2 \\
0.6 \\
108.3\end{array}$ & $\begin{array}{r}62.7 \\
13.7 \\
3.5 \\
2.0 \\
80.9\end{array}$ & $\begin{array}{r}7.2 \\
3.6 \\
1.4 \\
0.2 \\
12.4\end{array}$ & $\begin{array}{r}227.7 \\
66.5 \\
11.6 \\
2.0 \\
307.8\end{array}$ \\
\hline Partiai cut & $\begin{array}{l}3.1-7.9 \\
8.0-15.9 \\
16.0-27.9 \\
28.0+\end{array}$ & $\begin{array}{r}49.5 \\
7.3 \\
1.5 \\
=-\end{array}$ & $\begin{array}{r}68.6 \\
7.8 \\
1.8 \\
-7 \\
78.2\end{array}$ & $\begin{array}{r}68.6 \\
7.3 \\
3.3 \\
0.6 \\
79.8\end{array}$ & $\begin{array}{r}27.6 \\
1.4 \\
0.8 \\
0.2 \\
30.0\end{array}$ & $\begin{array}{r}214.3 \\
23.8 \\
7.4 \\
0.8 \\
246.3\end{array}$ \\
\hline
\end{tabular}

EASTERN WASHINGTON

$\begin{array}{crrrrrr}\text { Public } & 3.1-7.9 & 27.2 & 26.7 & 16.3 & 6.4 & 76.6 \\ & 8.0-15.9 & 5.3 & 5.4 & 5.1 & 3.2 & 19.0 \\ & 16.0-27.9 & 0.6 & 0.5 & 1.5 & 1.1 & 3.7 \\ \text { Total } & 28.0+ & \frac{0.1}{33.2} & \frac{0.2}{32.8} & \frac{0.2}{23.1} & \frac{0.2}{10.9} & \frac{0.7}{100.0} \\ \text { Private } & & & & & & \\ & 3.1-7.9 & 19.2 & 22.3 & 16.8 & 4.7 & 63.0 \\ & 8.0-15.9 & 3.2 & 3.1 & 2.8 & 1.4 & 10.5 \\ \text { Total } & 16.0-27.9 & 0.7 & 0.6 & 1.2 & 0.7 & 3.2 \\ & 28.0+ & 0.2 & \frac{0.1}{26.1} & \frac{0.2}{20.9} & \frac{0.2}{6.9} & \frac{0.5}{77.2}\end{array}$

'Does not include residue in large piles.

"'Sampling by diameter classes was different in Montana than that in the other states. 


\begin{tabular}{lcc}
\multicolumn{2}{c}{ Wood Density Values } \\
$\begin{array}{l}\text { State and } \\
\text { Resource area }\end{array}$ & $\begin{array}{c}\text { Wood densitios } \\
\text { Dry welght }\end{array}$ \\
\hline & (Pounds per cuble foot) \\
\hline Southeast Alaska & 24.3 & 54.87 \\
Idaho & 24.3 & 50.97 \\
Montana & 24.9 & 50.96 \\
Oregon: & & \\
Northwest & 26.0 & 54.39 \\
West Central & 26.4 & 54.73 \\
Southwest & 26.3 & 53.83 \\
Eastern & 24.4 & 50.25 \\
Washington: & & \\
Olymplc Pen. & 25.3 & 51.29 \\
Puget Sound & 25.2 & 53.40 \\
Southwest & 25.7 & 54.10 \\
Eastern & 25.2 & 52.18 \\
\hline
\end{tabular}

1 Average density values derived by weighting individual specie values by the proportion of inventory volume for that particular species. Density information from Wood Handbook.

\section{Biomass Relationships}

\section{A. Wood Densities}

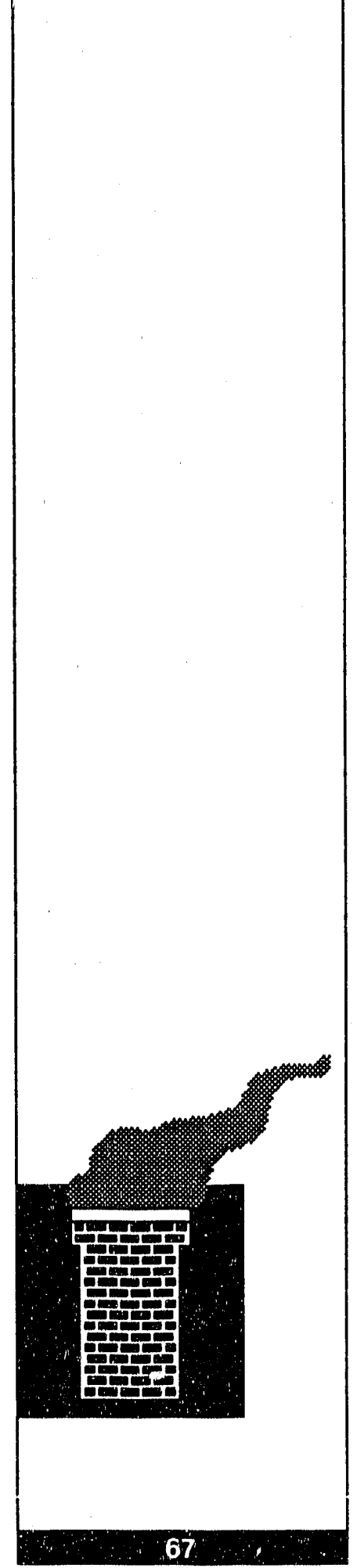


B. Bark Factors

Bark Welght Ratios by Species (oven dry basis)

\begin{tabular}{ll} 
Specles & $\begin{array}{c}\text { Ratio of bark } \\
\text { lo wood }\end{array}$ \\
\hline Douglas-flr & 0.15 \\
\hline True flirs & 0.18 \\
W. Hemlock & 0.13 \\
W. redcedar & 0.10 \\
Spruces & 0.10 \\
Ponderosa pine & 0.19 \\
W. white plne & 0.16 \\
Lodgepole plne & 0.08 \\
Larch & 0.10 \\
Incense ceder & 0.26 \\
Other conlifers & 0.15 \\
Red alder & 0.18 \\
Other hardwoods & 0.16 \\
\hline
\end{tabular}

C. Top of Tree

Top of Tree as a Percent of Total Stem '

\begin{tabular}{cc} 
Diameter & Percent of top \\
\hline 5.0 & 0.510 \\
7.0 & 0.190 \\
9.0 & 0.100 \\
11.0 & 0.060 \\
19.0 & 0.035 \\
29.0 & 0.033 \\
39.0 & 0.030
\end{tabular}

" Average values for top of tree from 4.0" top to tip of stem. No apparent differences exist between species, so one set of factors was used. Relationships are from tariff tables used in FIA inventory volume computations. 


\begin{tabular}{|c|c|c|c|c|}
\hline \multicolumn{5}{|c|}{ Branches as a Percent of Total Stem? } \\
\hline \multirow[b]{2}{*}{ Species } & \multicolumn{4}{|c|}{ Dlameter Class (inches) } \\
\hline & $5.0-8.9$ & $9.0-18.9$ & $19.0-28.9$ & $29.0+$ \\
\hline & \multicolumn{4}{|c|}{ (Percent) } \\
\hline Douglas-fir & 20.0 & 12.0 & 9.0 & 5.0 \\
\hline Ponderosa pine & 18.0 & 10.0 & 8.0 & 6.0 \\
\hline True flis & 20.0 & 12.0 & 7.0 & 5.0 \\
\hline Spruces & 38.0 & 15.0 & 10.0 & 6.0 \\
\hline Larch/redwood & 20.0 & 7.0 & 5.0 & 4.0 \\
\hline Hemlocks & 25.0 & 15.0 & 10.0 & 8.0 \\
\hline W. White pine & 15.0 & 8.0 & 6.0 & 4.0 \\
\hline Cedars & 25.0 & 15.0 & 8.0 & 6.0 \\
\hline Lodgepole pine & 15.0 & 12.0 & 10.0 & 8.0 \\
\hline Other softwoods & 20.0 & 12.0 & 8.0 & 5.0 \\
\hline Cottonwood/aspen & n 25.0 & 12.0 & 9.0 & 7.0 \\
\hline Red alder & 25.0 & 15.0 & 11.0 & 8.0 \\
\hline Oaks & 35.0 & 20.0 & 15.0 & 12.0 \\
\hline Other hardwoods & 25.0 & 12.0 & 10.0 & 8.0 \\
\hline
\end{tabular}

1 Average of values from various sources of biomass intormation. Does not include foliage.

\section{Branch Factors}

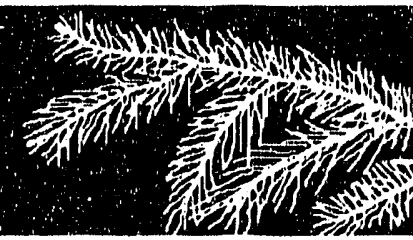




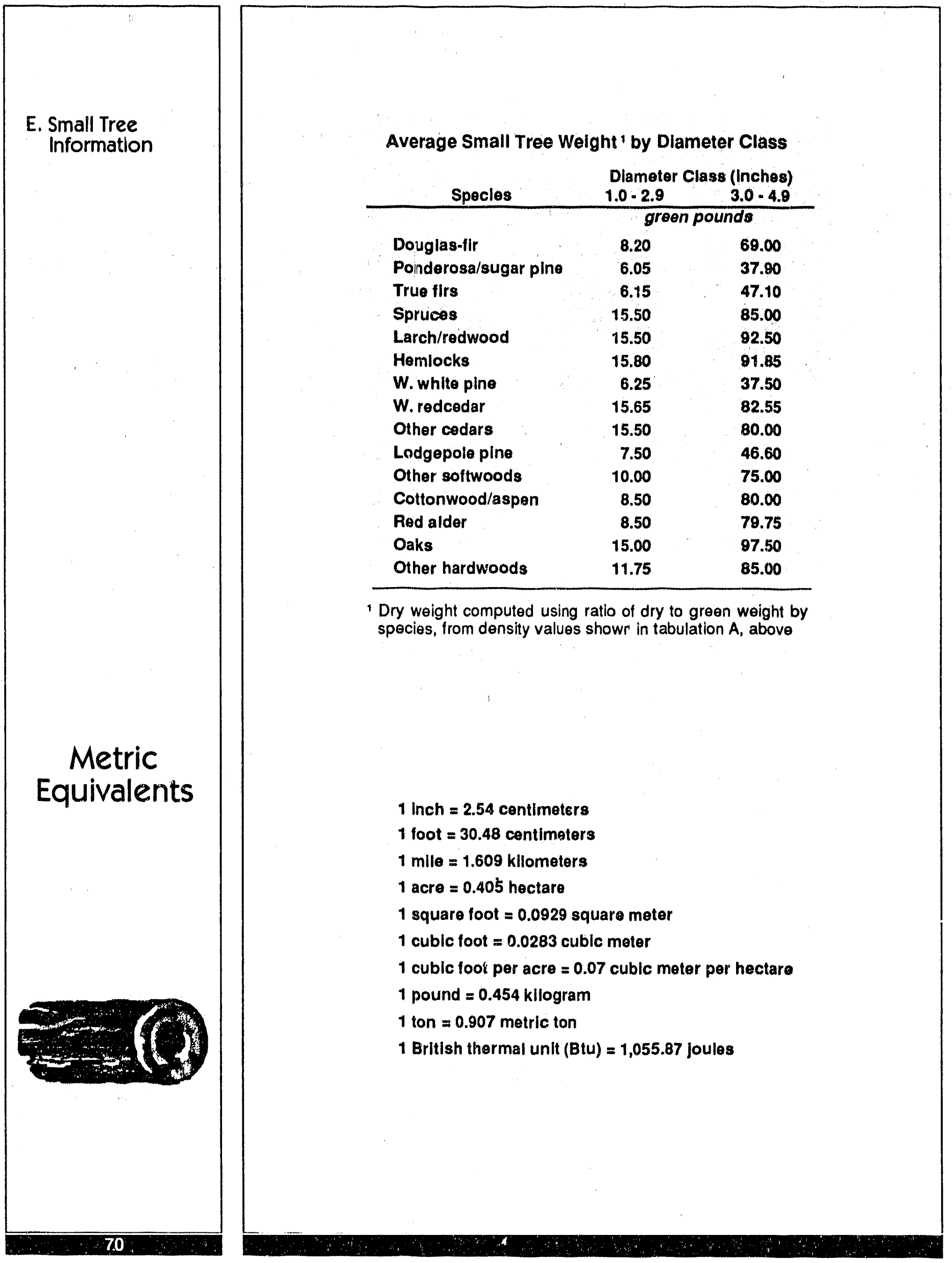



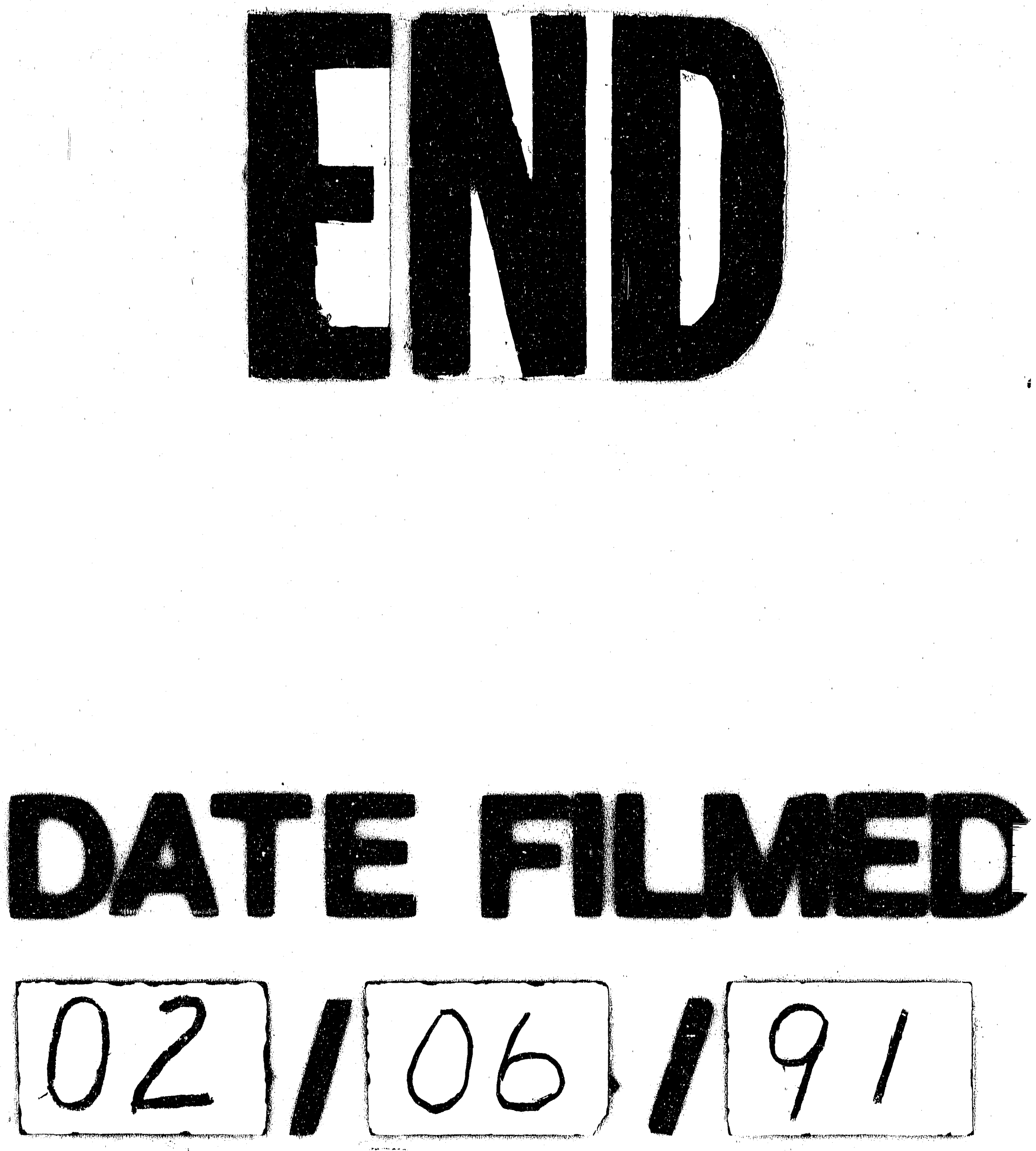
